1. 6 in

ELSEVIER

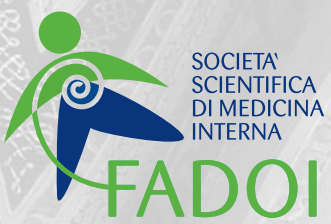

FEDERAZIONE DELLE ASSOCIAZIONI DEI DIRIGENTI OSPEDALIERI

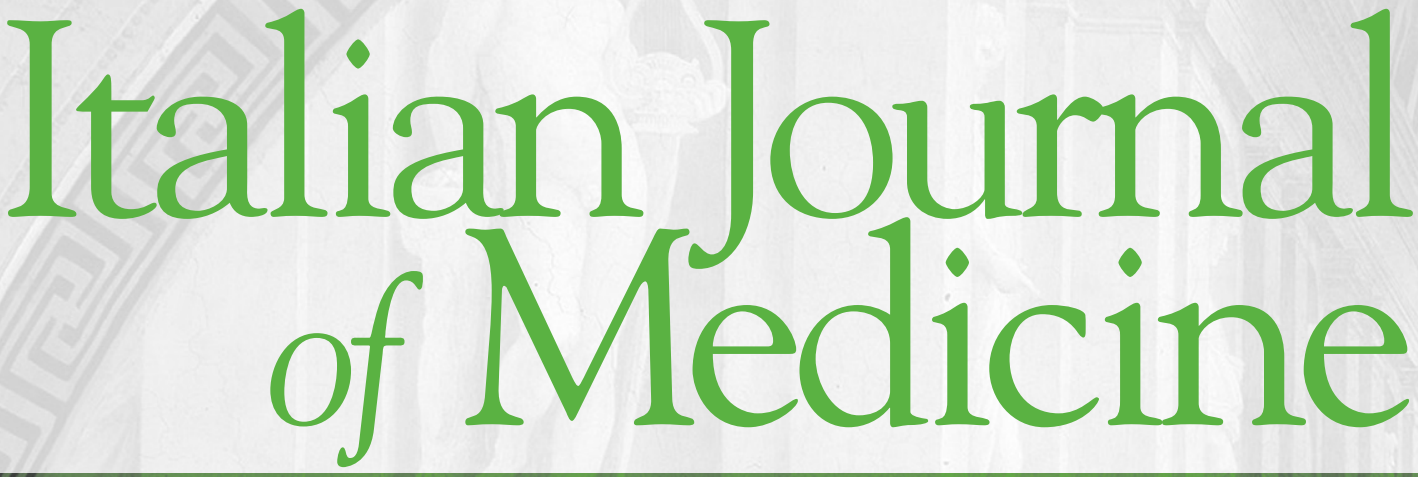

Organo Ufficiale della Federazione delle Associazioni dei Dirigenti Ospedalieri Internisti - FADOI

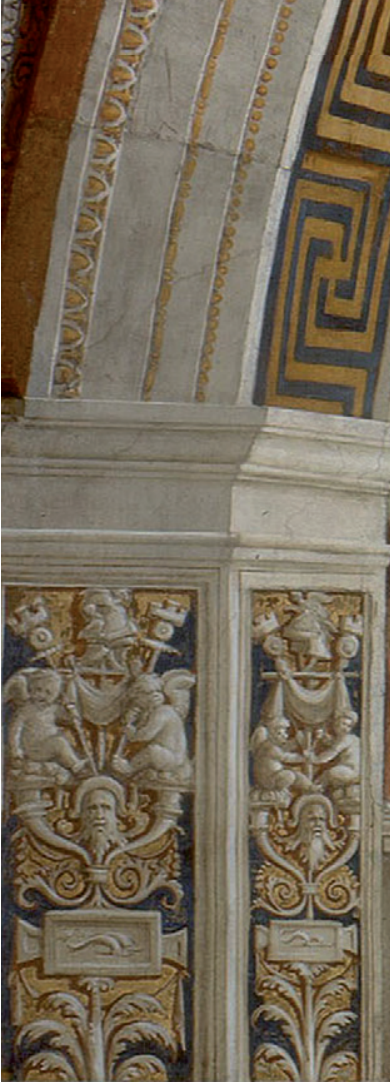

ditor

Roberto Nardi

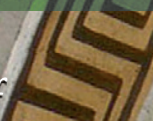

os torall
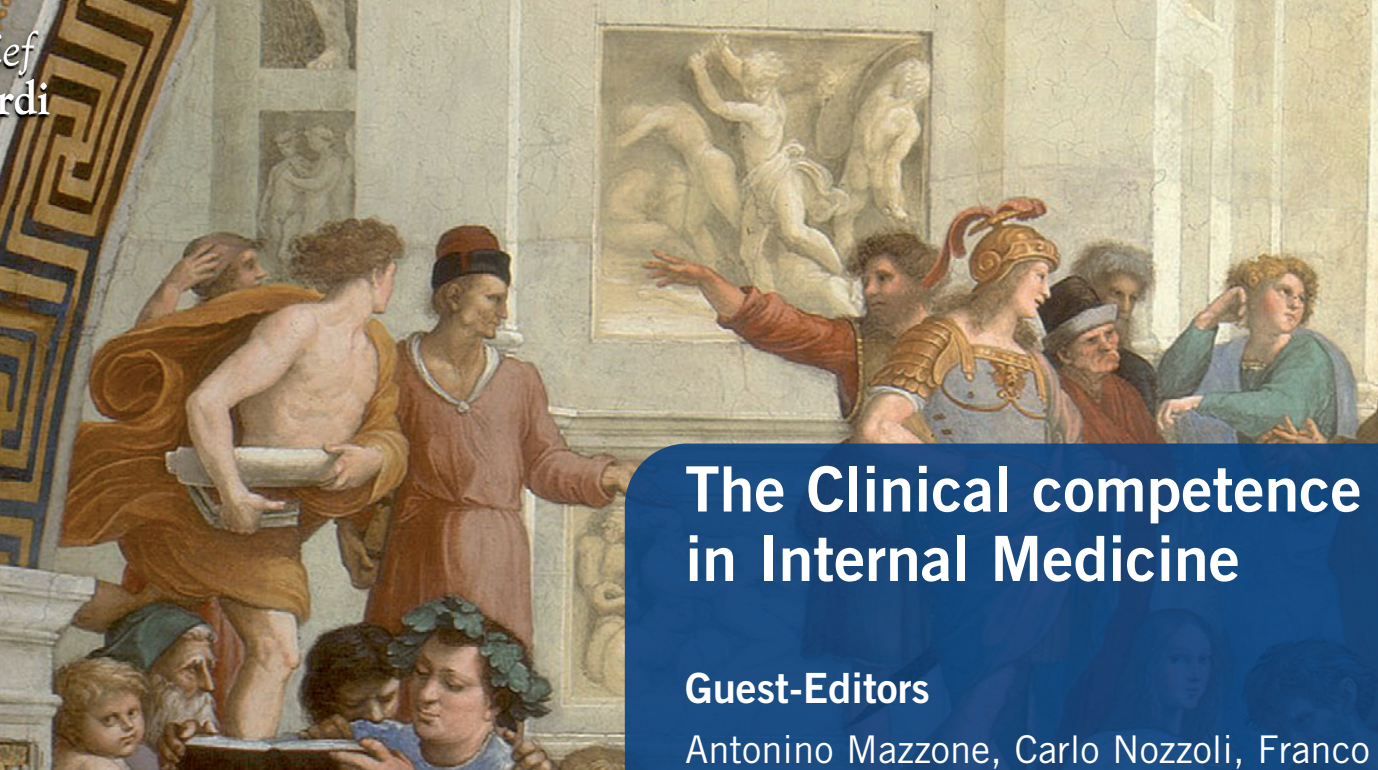

\title{
The Clinical competence in Internal Medicine
}

\section{Guest-Editors}

Antonino Mazzone, Carlo Nozzoli, Franco Berti,

Fabrizio Colombo, Cristina Filannino, Antonio Greco,

Giovanni Mathieu, Mauro Mattarei, Roberto Nardi, Michele Stornello 


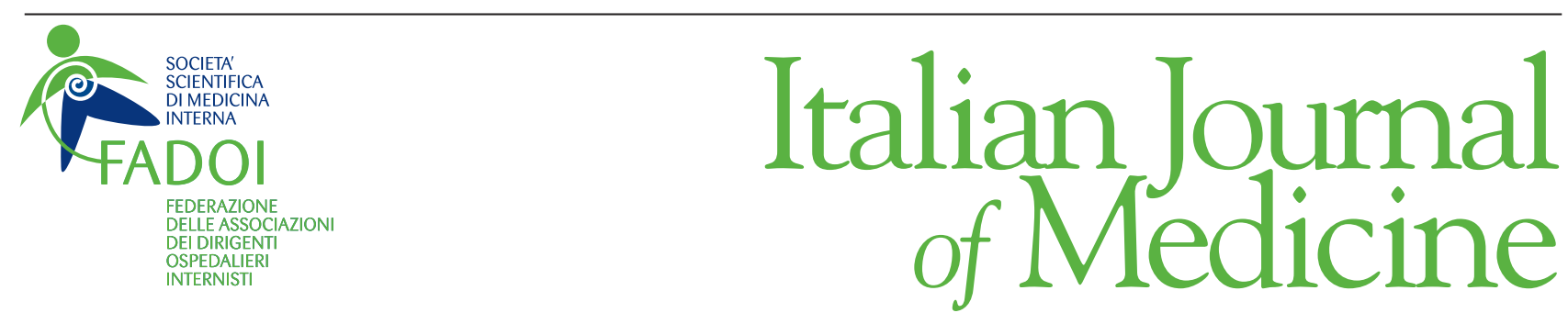

Organo Ufficiale della Federazione delle Associazioni dei Dirigenti Ospedalieri Internisti - FADOI

EDITOR IN CHIEF

Roberto Nardi

\section{CO-EDITORS}

Giorgio Ballardini Giuseppe Chesi Giovanni Gulli Giovanni Scanelli

Osp. Infermi, Rimini

Osp. C. Magati, Scandiano (RE)

Osp. Magg. SS. Annunziata, Savigliano (CN) AO Univ. Ferrara

\section{EMERITUS EDITORS}

Vito Cagli

Sandro Fontana

Italo Portioli
Univ. La Sapienza, Roma

Libero Professionista, Biella

Osp. Santa Maria Nuova, Reggio Emilia

\section{EDITORIAL BOARD}

Giancarlo Agnelli

Franco Berti

Mauro Campanini

Massimo Campieri

Mario Cottone

Domenico Cucinotta

Pier Paolo Di Micco

Salvatore Di Rosa

Leonardo Fabbri

Andrea Fontanella

Gianfranco Gensini

Gualberto Gussoni

Ido lori

Giancarlo Landini

Dario Manfellotto

Pietro Marino

Antonino Mazzone

Giovanni Mathieu

Carlo Nozzoli

Stefano Pallanti

Domenico Panuccio

Claudio Puoti

Giuseppe Remuzzi

Walter Ricciardi

Carlo Salvarani

Filippo Salvati

Generoso Uomo

Maurizio Ventrucci

Paolo Verdecchia

Giorgio Vescovo

Claudio Vitali
Univ. di Perugia

AO San Camillo, Roma

AO Maggiore della Carita, Novara

Policlino Sant'Orsola Malpighi, Bologna

AO Vincenzo Cervello, Palermo

Univ. di Bologna

Osp. Fatebenefratelli, Napoli

Villa Sofia di Palermo

Policlinico di Modena

Osp. Buonconsiglio Fatebenefratelli, Napoli

Univ. di Firenze

Centro Studi FADOI, Milano

Osp. Santa Maria Nuova, Reggio Emilia

Osp. Santa Maria Nuova, Firenze

Osp. Fatebenefratelli, Roma

Osp. Fatebenefratelli, Milano

Osp. Civile di Legnano (MI)

Osp. Agnelli di Pinerolo (TO)

AOU Careggi, Firenze

Ist. di Neuroscienze, Firenze

Osp. Maggiore, Bologna

Osp. Civile di Marino, Roma

Osp. Riuniti di Bergamo

Univ. Cattolica, Roma

Osp. Santa Maria Nuova, Reggio Emilia

Osp. Maria SS Immacolata, Chieti

Osp. Cardarelli di Napoli

Osp. di Bentivoglio, Bologna

Osp. R. Silvestrini, Perugia

Osp. San Bortolo, Vicenza

Osp. Villamarina, Piombino (LI)

\section{YOUNG EDITORS}

Dimitriy Arioli

Francesco Corradi

Pierpaolo Di Micco

Sirio Fiorino

Micaela La Regina

Adolfo lacopino

Maicol Onesta

INTERNATIONAL BOARD

Inder Anand

Stefan D. Anker

Edgardo Arena

$$
\text { Minneapolis, USA }
$$

Univ. of Minnesota Medical School,

Campus Virchow-Klinikum, Berlin, D Syrian Lebanese Hospital Buenos Aires, AR

I. Bourdel-Marchasson Clinique Centre Henri Choussat Hopital Xavier Arnozan, Bordeaux, $\mathrm{F}$

Vito M. Campese Keck School of Medicine of USC, Los Angeles, USA

R. Cataldi Amatriain International College of Internal Medicine, Buenos Aires, AR

Antonio Ceriello Institut d'Investigacions Biomèdiques August Pi i Sunyer, Barcelona, E

Andrew Davenport Univ. College London Medical School, London, UK

Ralph A. DeFronzo

Univ. of Texas Health Science Center, San Antonio, USA

Leonidas Duntas

Ariel Estruch Athens Medical School, Athens, GR Univ. Abierta Interamericana, Buenos Aires, AR

Samuel Z. Goldhaber Brigham and Women's Hospital,

Ana Matilde IL Boston, USA

Gene G Hunder Sociedad de Medicina Interna de Buenos Aires, AR

James R. Jett

Dan Justo

Anna Modelska

Manuel Monreal

Marco Pahor Piotr Ponikowski Cornel C. Sieber Reinhold Stocbrügger Astrid Stuckelberger Bernardo Tanur
Mayo Clinic College of Medicine, Rochester, USA National Jewish Health, Denver, USA Tel-Aviv Medical Center, Tel Aviv, IL Polish Academy of Sciences in Poznan, PL Hospital Universitari Germans Trias i Pujol, Badalona, $\mathrm{E}$ Univ. of Florida, Gainsville, USA Clinical Military Hospital, Wroclaw, PL Klinikum Nürnberg, Nürnberg, D University of Maastricht, NL Univ. of Geneva, CH ABC Medical Center, Santa Fe, MEX 


\section{Italian Journal of Medicine}

Organo Ufficiale FADOI

SOMMARIO

CONTENTS
ABSTRACT

S1 Abstract

Presentation / Presentazione

S2 Introduction to clinical competence

C. Nozzoli, A. Mazzone

ORIGINAL ARTICLE/ ARTICOLO ORIGINALE

S3 Evaluation models and items of clinical competence for the hospital physicians in internal medicine

R. Nardi, G. Mathieu, F. Berti, C. Filannino, A. Greco, C. Nozzoli, A. Mazzone, the working group FADOI-SDA BOCCONI

ABBREVIATIONS AND ACRONYMS/ABBREVIAZIONI E ACRONIMI

S14 Legend of abbreviations and acronyms

REFERENCES/ BIBLIOGRAFIA

\section{S17 Bibliografia}

APPENDIX/ APPENDICE

I Grids 


\section{Abstract}

\author{
KEYWORDS \\ Clinical competence; \\ Internal Medicine; \\ Standard reference; \\ Learning-formation; \\ Curriculum for hospital Internists.
}

\section{Background}

The definition of professional competence is of fundamental importance in the current health context, physicians finding themselves working in an environment in which the rapid obsolescence of technical-scientific knowledge imposes upon them a continuous review of their knowledge and ability. FADOI (Federazione delle Associazioni dei Dirigenti Ospedalieri Internisti/Federation of the Associations of Hospital Doctors of Internal Medicine in Italy) has as its main mission that of improving, through training and clinical research, the technical-scientific capacity of hospital internists.

\section{Discussion}

"Clinical competence" is the result of technical knowledge, ability, capacity of the professional, managerial, relational and operative qualities of each individual specialist in his/her specific care context. All this presupposes the optimal balancing of several components - knowing, being able to do and being able to be - in a perspective of interaction between doctor and patient, and practical solutions for the resolution of clinical problems. Unfortunately, medical competence cannot, by itself, be guaranteed by academic titles or specialist self-referentiality, nor does it constitute a mere professional ideal.

\section{Results and proposals}

FADOI, in collaboration with SDA-Bocconi, has designed a path for the identification of the professional competence of hospital doctors of Internal Medicine in Italy. Our project is proposed as a specific instrument of reference for the definition of the professional capability of hospital specialists in Internal Medicine, upon the data furnished by "Minerva Project", relative to 161,961 Internal Medicine hospital discharge records.

The map of the proposed competences in Internal Medicine is articulated into two distinct parts: one relative to personal organisational/managerial characteristics and another one strictly specialist/professional related. In the evaluation of professional growth, three different levels (basic, optimal, excellent professionalism) were selected. The concept of "distinctive professionalism" was introduced regarding the capacity of being able to carry out a professional activity at a particular level as a function of each pathology considered and when useful to furnish a further sub-specialist response to the specific needs of the health of the patient.

\section{Conclusions}

The work carried out in our experience constitutes an indispensable premise, precisely because it is impossible to "credit" or "certify" competence without having first established a standard reference curriculum. The definite axes with the grid proposed of the competences (which moreover - will have to undergo "maintenance" over time) constitute "the fabric" for the establishment of paths of learning-formation, oriented to the acquisition of the key competences of the specialist in Internal Medicine and for the activation of a virtual cycle of improvement of clinical practice. The questions to face in the near future are, substantially, numerous and complex. With additional constructive criticism, integrative proposals and/or emendation and the commitment of everyone stakeholder, together, we will do it. 


\section{Introduction to clinical competence}

FADOI (Federation of the Associations of Hospital Doctors of Internal Medicine) has as its fundamental mission that of improving, through training and clinical research, the technical-scientific capacity of hospital internists. Starting from this presupposition, we could not refuse to address the subject, of great current interest, of the evaluation of the professional competence of the chief of medicine. Defining what makes a good doctor is a greatly debated question at the national and the international levels. A scientific association, such as FADOI, has at least three reasons for tackling the verification and professional development of the specialist in Internal Medicine.

- the necessity of guaranteeing quality health services;

- the epidemiological changes, polypathologies, comorbidities, scarce scientific evidence in real patients, all challenges for which one needs to be prepared to respond;

- credibility since the medical profession is one which has the privilege of regulating itself, thanks to its own history and professional ethics.

"Clinical competence" is the result of technical knowledge, ability and capacity of the professional, and the managerial, relational and operative qualities of each individual specialist in his/her specific care context. All this presupposes the optimal balancing of several components - knowing, being able to do and being able to be - in a perspective of interaction between doctor and patient, and practical solutions for the resolution of clinical problems. Unfortunately, medical competence cannot, by itself, be guaranteed by academic titles or specialistic self-referentiality nor does it constitute a mere professional ideal. For this reason, the quality of treatment must be defined on the basis of specific indicators. Clinical science and the experience of the doctor must complement each other in managing the actual patient. In fact, experience, scientific knowledge, evidence-based medicine and clinical common sense constitute the basic elements of medical competence today for treating adult, elderly, critical and fragile patients and those with hospital discharges.

In reality, the effort which FADOI (our Scientific Society of Internal Medicine hospital doctors) is making has a double significance for the growth of the professional value of the specialist in Internal Medicine because the creation of an instrument with which to evaluate what the specialist in internal medicine knows will involve, once applied, better comprehension of the formative needs of our doctors and, not of less importance, the availability of a powerful means of planning professional updating.

In undertaking this path with SDA Bocconi, we first established a working group to determine the fundamental items of the required competences, identifying three levels of professionalism (basic, optimal, excellent), which we then compared with a group of professionals involved in our scientific association in order to obtain a shared consensus of the work carried out.

The examination of competence ranged across the different aspects - from human capacities in a general, relational and communicative sense to those more strictly technicalscientific - by means of the analysis of a large number of pathologies and clinical situations, also regarding emergencies and critical patients. The complexity of Internal Medicine has made this path particularly difficult, but we feel that we have laid down the basis for the further development of these topics hoping that this project can also make an important contribution to the entire scientific community.

This project therefore represents the first important step in defining a new role for scientific associations as promoters of development and the continuous monitoring of the individual professionalism of the physician.

\section{Carlo Nozzoli ${ }^{\mathrm{a}}$, Antonino Mazzone ${ }^{\mathrm{b}}$ \\ ${ }^{a}$ President FADOI (Federazione delle Associazioni Dirigenti Ospedalieri Internisti) \\ ${ }^{\mathrm{b}}$ President Fondazione FADOI}




\title{
Evaluation models and items of clinical competence for the hospital physicians in internal medicine
}

\author{
Roberto Nardi ${ }^{a}$, Giovanni Mathieu ${ }^{b}$, Franco Berti ${ }^{c}$, Cristina Filannino ${ }^{d}$, \\ Antonio Greco $^{e}$, Carlo Nozzoli ${ }^{f}$, Antonino Mazzone ${ }^{g}$, the working group \\ FADOI-SDA BOCCONI ${ }^{1}$
}

\author{
a UOC Medicina Interna, Ospedale Maggiore, Azienda USL di Bologna \\ ${ }^{\mathrm{b}}$ UOC Medicina Interna, Ospedale Edoardo Agnelli, Pinerolo (Torino) \\ c UOC Medicina Interna, Ospedale San Camillo Forlanini, Roma \\ ¿ SDA Bocconi, Milano \\ e UOC Geriatria, Ospedale Casa Sollievo Della Sofferenza, S Giovanni Rotondo, Foggia \\ ${ }^{f}$ UOC Medicina Interna, Azienda Ospedaliera Careggi, Firenze \\ ' UOC Medicina Interna, Ospedale Civile di Legnano, Milano
}

\section{Introduction}

The question of the definition of professional competence, its evaluation and its development is of fundamental importance in the current health context, physicians finding themselves working in an environment in which the rapid obsolescence of technical-scientific knowledge imposes upon them a continuous review of their knowledge and ability. Frequent organisational and managerial changes require rapid compliance with definitive innovative models, with suitable proactive capacities and sufficient response flexibility on the part of the professionals. An in-depth consideration of professional competence is therefore becoming an inescapable requirement under both clinical and the ethical profiles. Compliance with a path of evaluation of one's own working performance represents an essential moment in the continuing development of competence for the physician and an improved capacity to respond to the needs of citizens.

The Mission of Internal Medicine is aimed at improving the quality and efficacy of diagnostic, therapeutic and medical

\footnotetext{
${ }^{1}$ Editors: Antonino Mazzone, Legnano (MI); Carlo Nozzoli, Firenze; Franco Berti, Roma; Fabrizio Colombo, Milano; Cristina Filannino, Milano; Antonio Greco, Acquaviva delle Fonti (BA); Giovanni Mathieu, Pinerolo (TO); Mauro Mattarei, Rovereto (TN); Roberto Nardi, Bologna; Michele Stornello, Siracusa; Irene Stornello, Roma; Stefania Nardi, Bologna.

Supervisors: Marco Candela, Fabriano (AN); Giorgio Cioni, Pavullo (MO); Marco Grandi, Sassuolo (MO); Gualberto Gussoni, Milano; Ido lori, Reggio Emilia; Paolo Leandri, Bologna; Francesco Cipollini, Ascoli Piceno; Andrea Fontanella, Napoli; Domenico Panuccio, Bologna; Giuliano Pinna, Asti; Filippo Salvati, Chieti; Francesco Sgambato, Benevento; Maurizio Ventrucci, Bologna.

Consensus Group: Giorgio Ballardini, Rimini; Riccardo Battelli, Angera (VA); Alberto Camaiti, Livorno; Michele Cannone, Canosa di Puglia (BT); Efisio Chessa, Ghilarza (OR); Giuseppe De Mattheis, Citta' Sant'Angelo (PE); Audenzio D’Angelo, Palermo; Roberto Frediani, Verbania-Domodossola; Anna Gargiulo, Caserta; Giovanni Gulli, Savigliano (CN); Giuseppe Lombardo, Milano; Pietro Marino, Milano; Bruno Mongiardo, Viterbo; Lionello Parodi, Savona; Ruggero Pastorelli, Roma; Cecilia Politi, Isernia; Alfredo Porro, Rho (MI); Antonino Pratico', Bagno di Romagna (FC); Fabio Presotto, Este (PD); Pier Giorgio Rabitti, Napoli; Massimo Rondana, San Vito al Tagliamento (PN); Pierangelo Santori, San Benedetto del Tronto (AN); Francesco Serafini, Mestre (VE); David Terracina, Roma.

Young Consensus Group: Raffaella Bassu, Pescia (PT); Luca Bonanni, Mestre (VE); Luigi Carbone, Roma; Mariangela Di Lillo, Fano (PU); Paola Gnerre, Micaela La Regina, Milano; Domenico Montemurro, Adria (RO); Maicol Onesta, Fabriano (AN); Roberta Re, Novara; Daniela Tirotta, Cattolica (RI).
} 
The prerogatives required

in Internal Medicine

Ability of clinical synthesis

Capacity of diagnosis and therapy

Elevated functional flexibility

referred to patients with multiorgan,

complex or systemic pathologies

or with diseases of medical character

coexisting in the same individual

Figure 1 The distinctive prerogatives of Internal Medicine.

institutional services for the adult ill (Fig. 1), guaranteeing the appropriateness of hospital admission and therapy, recognising and treating emergencies so that the hospitalised patient is correctly taken charge of for the definition and management of his/her total course of treatment, until being entrusted to the doctor in charge and/or the network of services. Among the institutional objectives of a scientific association, there is that of representing a "place of culture" in which doctors can develop their own knowledge and their own distinctive competence by means of adhesion to the initiatives proposed in the field of research and the training environment, favouring a comparison between different working experiences and clinical practice, and developing the particular characteristics of the discipline it represents.

Anticipating the requirements which could be imposed by future initiatives of accreditation at a regional or national level - by means of legislative or contractual provisions orienting itself to already consolidated international experiences, FADOI thought it better to construct an experimental route of monitoring and evaluation of the competence of its members who, voluntarily, desire to move away from specialistic self-referentiality and are willing to test themselves using an especially identified system of indicators and good clinical practice. We are strongly convinced that management of this process by means of the active involvement of scientific associations can not only gather important contributions regarding the definition of the performance indicators but also leave enough space for the development of innovative projects which see the direct participation of whoever is involved in daily doctoring and knows the existing situation. This project, originating from a partnership between FADOI and SDA Bocconi, represents the first important step in defining a new role for scientific associations as promoters of the development and continuous monitoring of individual professionalism of the specialist in internal medicine. The intended objective to be pursued is aimed at clarifying the activities, experiences and competence of specialists in Internal Medicine which are necessary to carry out their role of being able to construct a training path based on the detection of acquired knowledge and technicalscientific ability.
The distinguishing characteristics of Internal Medicine are based on the following elements:

- pluripotency, understood as the capacity of developing and integrating knowledge and multiple competences;

- flexibility, which consists of the capacity to adapt and modify intervention priorities both for the individual patient and in response to the epidemiological necessities of the area;

- functional interdependence, with the knowledge that the case mix of patient load requires reciprocal dependence upon various partners but, at the same time, requires a single "director" for each individual case;

- cost-saving measures, which require efficient management of beds (however, they are less expensive when compared to those in highly specialised centres), with a different turnover determined by the frequent hospitalisation of patients with unresolved problems or those with elevated complexity due to the presence of multiple comorbidities and the interaction of physiopathological, clinical and socio-welfare problems.

The summary of the above-mentioned characteristics is oriented towards a professional in continuous training, conscious of his/her own role in the organisational context, with congruent behaviour, multidimensional capabilities and willing to be evaluated (Fig. 2).

Professional evaluation represents a challenge for "cultural" change, required for those who work in the sphere of the health system (public or private affiliate with the national health service), who accept being "observed in a constructive way" with respect to the role that they have, what they do and what they "should do". It is evident that the process of evaluation has to be characterised by explicit elements which guarantee them objectivity and transparency on the methodology utilised.

The evaluation of competence proposed by FADOI utilises specific reference standards and indicators of a professional nature with the aim of verifying whether the medical director is a "good professional" or sufficiently "expert" in his/her own work, capable of resolving specialistic problems of elevated complexity within his/her field of expertise.

The project is not proposed as an alternative to decisions and instruments typically institutional and/or private regarding the policies of human resources management but it is proposed as a specific instrument of reference for the formation, evaluation and monitoring of the professional capability of hospital specialists in Internal Medicine.

\section{The grid of the "dominions of competence" proposed}

The work hypothesis on which the content of "clinical competence" is based is that of defining a grid of evaluation of the competence of the specialist in Internal Medicine with the aim of grading the levels of decisional responsibility and knowledge of the role (useful for achieving a form of institutional accreditation) and of constructing a path of formative progression and professional growth. The final objective is that of outlining paths of professional development suitable for growth in the sphere of the specialistic discipline. To that end, FADOI, in collaboration with SDA Bocconi, has 

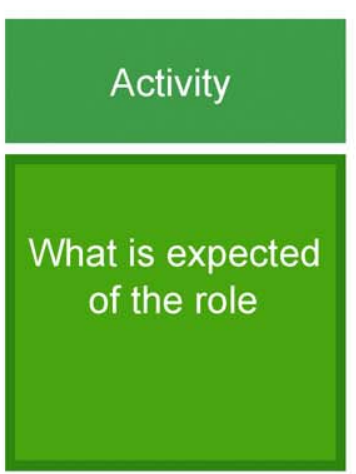
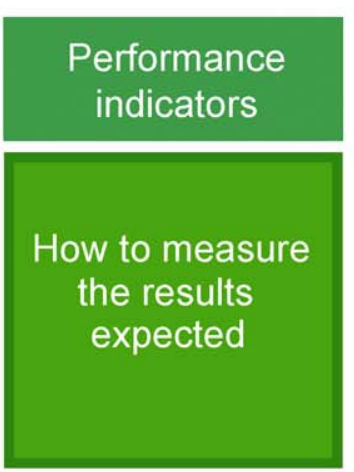
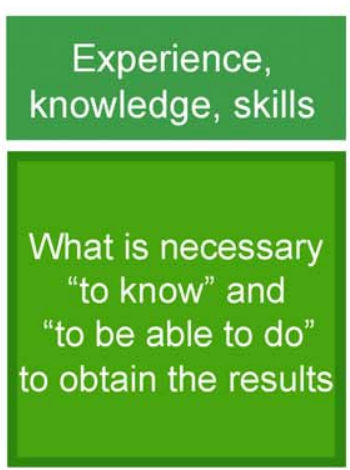
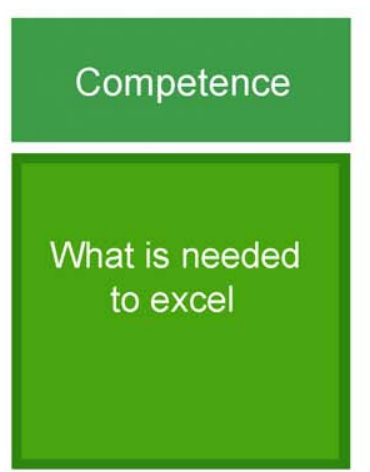

Figure 2 Measurement of the contents of the role of the specialist in Internal Medicine.

designed and realised a path of active interaction with a group of Managers of the Complex Structure of Internal Medicine operating in the entire national territory, for the identification of the professional competence of the hospital directors of internal medicine who want to voluntarily adhere to the project, also with the aim of possible accreditation and/or certification (we refer to the program "Evaluation of clinical competence in Internal Medicine: integration between professional competence and managerial competence of the evaluators, Monday 14 June 2010, SDA Bocconi, Milan).

The map of the competence characteristic of a specialist in Internal Medicine is articulated in two distinct parts, one strictly specialistic/professional and one organisational/ managerial relative to personal characteristics, with the following objectives:

- establishing paths of good clinical practice, verifying, validating and improving the professional competence of managers by means of innovative formative methodologies suitable for favouring professional growth;
- facilitating the work of the hospital managers and the hospital directors of Internal Medicine in clinical and managerial activities with the aim of pursuing appropriate management of the resources in agreement with the objectives within this context.

The contents of the project do not currently regard the professional development of the hospital directors of Internal Medicine of any single structure, single departmental structure or complex structure.

In constructing the grid, for the identification of the various dominions of competence in Internal Medicine in the various nosological environments, for the most part, the data furnished by Project Minerva, relative to $130 \mathrm{Com}$ plex Operative Units (COU) of Internal Medicine and 161,961 hospital discharge records (HDRs) in which the principal pathologies afferent to Internal Medicine Departments, were considered (Fig. 3).

Beginning with this basic epidemiological analysis, the principal pathologies which, for statistical-epidemiological

\begin{tabular}{|c|c|c|}
\hline \multicolumn{3}{|c|}{$\begin{array}{c}\text { Project Minerva } \\
130 \text { Internal Nedicine units in Italy } \\
161,961 \text { hospital discharge records relative to } 2001-2002\end{array}$} \\
\hline DRG & Diagnosis & No. of cases \\
\hline 127 & Cardiac insufficiency and shock & $12,956=8 \%$ \\
\hline 088 & Chronic obstructive pulmonary diseases & 7,774 \\
\hline 014 & Specific cerebro-vascular diseases, except TIA & 5,830 \\
\hline 134 & Arterial hypertension & 4,858 \\
\hline 089 & Simple pneumonia and pleurisy, age +17 years, with complications & 4,372 \\
\hline 202 & Hepatic cirrhosis and alcoholic hepatitis & 4,210 \\
\hline 395 & GR anomalies, age +17 years, without complications & 4,049 \\
\hline 294 & Diabetes, age +35 years & 4,040 \\
\hline 015 & TIA and pre-cerebral occlusion & 3,725 \\
\hline 183 & Esophagitis, gastro-enteritis, miscellaneous & 3,703 \\
\hline 087 & Pulmonary edema and respiratory insufficiency & 3,077 \\
\hline \multicolumn{3}{|c|}{ Wide dispersion of diagnosis related groups: 35 different DRC } \\
\hline
\end{tabular}

Figure 3 Project Minerva (Source: Bellis P. In: Medicina interna. Complessità e metodologia. Torino: CSE, 2004). 
Table 1 Content of the levels of professionalism proposed.

\begin{tabular}{|c|c|c|c|}
\hline I & II & III & \multirow{2}{*}{ Distinctive competence } \\
\hline Basic professionalism & Optimal professionalism & Excellent professionalism & \\
\hline $\begin{array}{l}\text { Corresponds to essential specialistic } \\
\text { competence, such as "core } \\
\text { curriculum", minimum basis for access } \\
\text { to work (e.g. necessary to carry out } \\
\text { the duties in all operating contexts) in } \\
\text { an initial phase aimed at a path of } \\
\text { additional formation }\end{array}$ & $\begin{array}{l}\text { Corresponds to the best } \\
\text { specialistic competence } \\
\text { for managing complex } \\
\text { patients, practiced } \\
\text { according to defined } \\
\text { reference parameters, } \\
\text { in a consolidated phase of } \\
\text { formative development }\end{array}$ & $\begin{array}{l}\text { Corresponds to } \\
\text { specialistic competence } \\
\text { far superior to the } \\
\text { average, also practiced } \\
\text { in an institutional setting } \\
\text { of high curative intensity, } \\
\text { in an advanced phase } \\
\text { of formative and didactic } \\
\text { development }\end{array}$ & $\begin{array}{l}\text { Corresponds to the specific } \\
\text { additional competence, } \\
\text { practiced in the sphere of } \\
\text { Internal Medicine, in which } \\
\text { the professional is a } \\
\text { reference for the hospital } \\
\text { and/or other professionals, } \\
\text { also external, in the sphere } \\
\text { of a niche and/or sub- } \\
\text { specialistic formative } \\
\text { development }\end{array}$ \\
\hline $\begin{array}{l}\text { Requires supervision and additional } \\
\text { training }\end{array}$ & $\begin{array}{l}\text { Is competent to carry out } \\
\text { the assigned work } \\
\text { autonomously without } \\
\text { needing supervision }\end{array}$ & $\begin{array}{l}\text { Is competent to train } \\
\text { other professionals } \\
\text { in Internal Medicine }\end{array}$ & $\begin{array}{l}\text { Is competent to train } \\
\text { other professionals } \\
\text { in the specific/ } \\
\text { sub-specialistic spheres } \\
\text { of Internal Medicine }\end{array}$ \\
\hline
\end{tabular}

relevance, importance and gestational criticality were considered the most relevant by the working group, were selected with the aim of specifically analysing the required competence.

In the proposal for the evaluation of professional growth, three different levels in which the acquisition of a higher level presupposes possession of the lower one were selected. The integration and summary of the various levels "generally" define the complete path of the specialist in Internal Medicine from which a basic professional can attain an optimal, or excellent, level of professionalism if he "fully" responds to the requisites required for each individual level. The levels of "gradation" considered epitomize elements referring to knowledge, ability and attitude according to the various phases of formative development and classified as in Table 1.

The concept of "distinctive competence" was introduced regarding the capacity of being able to carry out a professional activity at a particular level as a function of each pathology considered and when it is useful to furnish a response to the specific needs of the health of the patient. It can be possessed by the physician in addition to that required for specialistic functions and refers to the performance of medical sub-specialistic services.

Regarding the personal characteristics of the specialist in Internal Medicine, the FADOI working group and SDA Bocconi defined some priorities relative to the various behavioural capacities taken from the competence model of McClelland 1973 (2) and the concept of competence, understood in the sense of an "intrinsic individual characteristic casually linked to an efficacious or superior performance of a task or in a situation, and which is measured on the basis of an established criterion" (3). The capacities selected (emotional, relational, managerial, intellectual and innovative), subdivided into various levels, represent the integrating feature and consolidation of the personality of an individual, capable of predicting behaviour in a wide range of situations and work tasks, causing and predicting, according to standard criteria, the positive or negative results obtainable and/or obtained (Table 2).

In addition to these elements, in the evaluation of "professionals", the capacity of the individual physician to adhere to a concept of "professional interdependence" in the total hospital context or "sub-specialistic self-referentiality" should be considered, generally correlated to the formal role of the individual professionals (Fig. 4).

The basic values of teamwork, such as success factors ("winning team") for each individual team have to be explicitly shared, in function of the objectives, verifying the performance data on the basis of institutional processes and verification audits of the differences with the aim of reaching institutional objectives (Fig. 5).

\section{Monitoring the differences}

\section{The path of consensus for the elaboration of the final grid}

The path followed for the final proposition of the grid was that of delineating, in Fig. 3 using a Delphi-Rand type method which, recognising the value of the opinion, experience and intuition of the experts, permits the use of available information when there is a lack of univocal full scientific knowledge (4).

The path is based on the presentation, by a committee made up of 10 organisers, of the initial elaboration of the grid to a group of 13 "expert supervisors" who, independently expressed an opinion, integrating or modifying the content of the draft received. After this revision, the grid was presented to the consensus group ( 24 chiefs of Internal Medicine and 10 young specialists in Internal Medicine, subdivided into three subgroups) who was asked to review, for the part assigned to each group, the entire project with a critical analysis for each individual item, using three possible options: complete agreement, complete disagreement, alternative version 
Table 2 Selection of the most significant personal characteristics and capacities of each professional level according to the FADOI-SDA BOCCONI working group.

A

\begin{tabular}{|c|c|c|}
\hline Basic professionalism & Optimal professionalism & Excellent professionalism \\
\hline & Area: EMOTIONAL CAPACITY & \\
\hline \multirow[t]{3}{*}{ Self-control and stress management } & Self-control and stress management & Self-control and stress management \\
\hline & Conflict management & Conflict management \\
\hline & Area: RELATIONAL CAPACITY & \\
\hline $\begin{array}{l}\text { Availability for interpersonal } \\
\text { relationships }\end{array}$ & $\begin{array}{l}\text { Availability for interpersonal } \\
\text { relationships }\end{array}$ & Negotiation \\
\hline Group work & Conviction & Public speaking \\
\hline Conviction & Public speaking & Management of groups and meetings \\
\hline \multirow[t]{3}{*}{ Public speaking } & Management of groups and meetings & Management of human resources \\
\hline & Leadership & Leadership \\
\hline & Area: MANAGERIAL CAPACITY & \\
\hline Planning one's own work & Organisation & Tenacity/realisation \\
\hline Organising one's own work & Decisiveness & Planning \\
\hline Operative control & Orientation to results & Organisation \\
\hline Initiative & & Orientation to results \\
\hline \multicolumn{3}{|l|}{ Tenacity/realisation } \\
\hline \multicolumn{3}{|l|}{ Decision making } \\
\hline & Area: INTELLECTUAL CAPACITY & \\
\hline Resolution of operative problems & Gathering and data processing & Analysis \\
\hline \multirow[t]{4}{*}{ Gathering and elaboration of information } & Analysis & Problem solving \\
\hline & Problem solving & Formulation of plans and strategies \\
\hline & Compilation of reports & \\
\hline & Area: INNOVATIVE CAPACITY & \\
\hline Adaptability/flexibility & Propensity for new things & Propensity for new things \\
\hline
\end{tabular}

(in that case, it was necessary to specify the propositions suggested). The answers obtained by the panel were followed by a detailed analysis of the opinions (common or divergent points of view, with the pertinent reasons, with respect to the initial version), an analytic calculation of the sum of the opinions and the shared convergence, and the elaboration of the definitive proposition.

In substance, the fundamental objective was that of sharing the final document within FADOI itself and then to present it to the institutions, the medical-scientific community and the citizens directly concerned.

\section{What remains to be done?}

\section{Define the modalitites for evaluating clinical competence}

In the clinical environment: the methods and instruments proposed for the evaluation of professional competence are different (Tables 3 and 4 ). In the majority of cases, the services are measured on the basis of the modality of work, or in reference to the "process". Measuring on the basis of treatment, results or volume of activity is more difficult and problematic [1,2].

Apart from the modalities of evaluation that FADOI would like to choose from among the various options available, it must be confirmed that professional competence is contextdependent: knowledge, ability, attitude of the specialist in internal medicine are not equal in all operative realities and the abilities required for each individual physician vary on the basis of the characteristics of the health organisation and the clinical context in which one finds him/herself operating. In fact, in large hospitals having the most complete articulation of specialised areas, the modulation of the case mix in departments of internal medicine prevalently tends to exclude patients with marked specialised capabilities, which are, for the most part, entrusted to departments with specific competences, consequently affecting the professional ability of the individual physicians. On the contrary, in small and/or medium-sized hospitals, in the absence of specialised structures, the aptitude required of the specialist in internal 


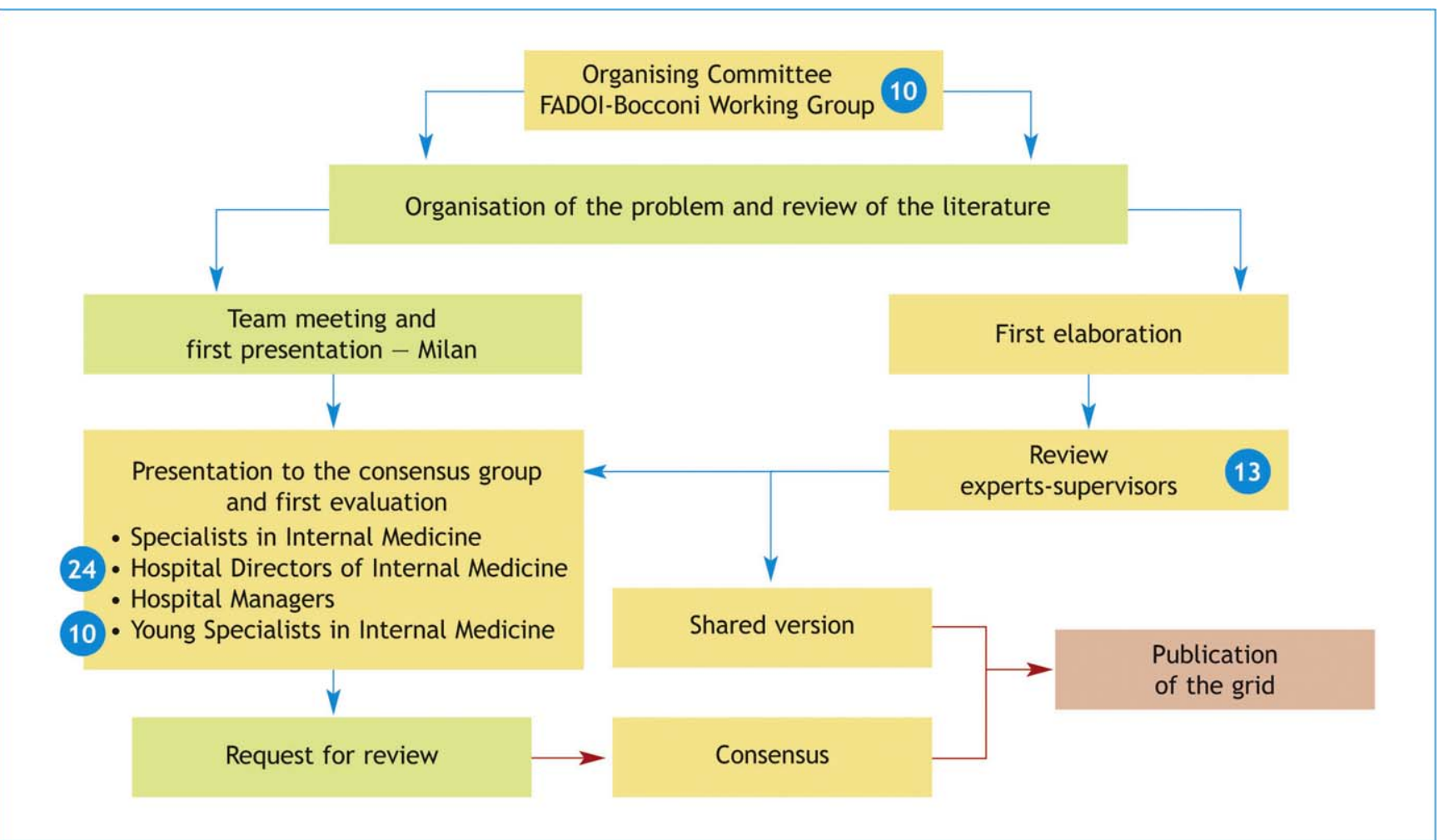

Figure 4 Method applied to the FADOI-Bocconi Project.

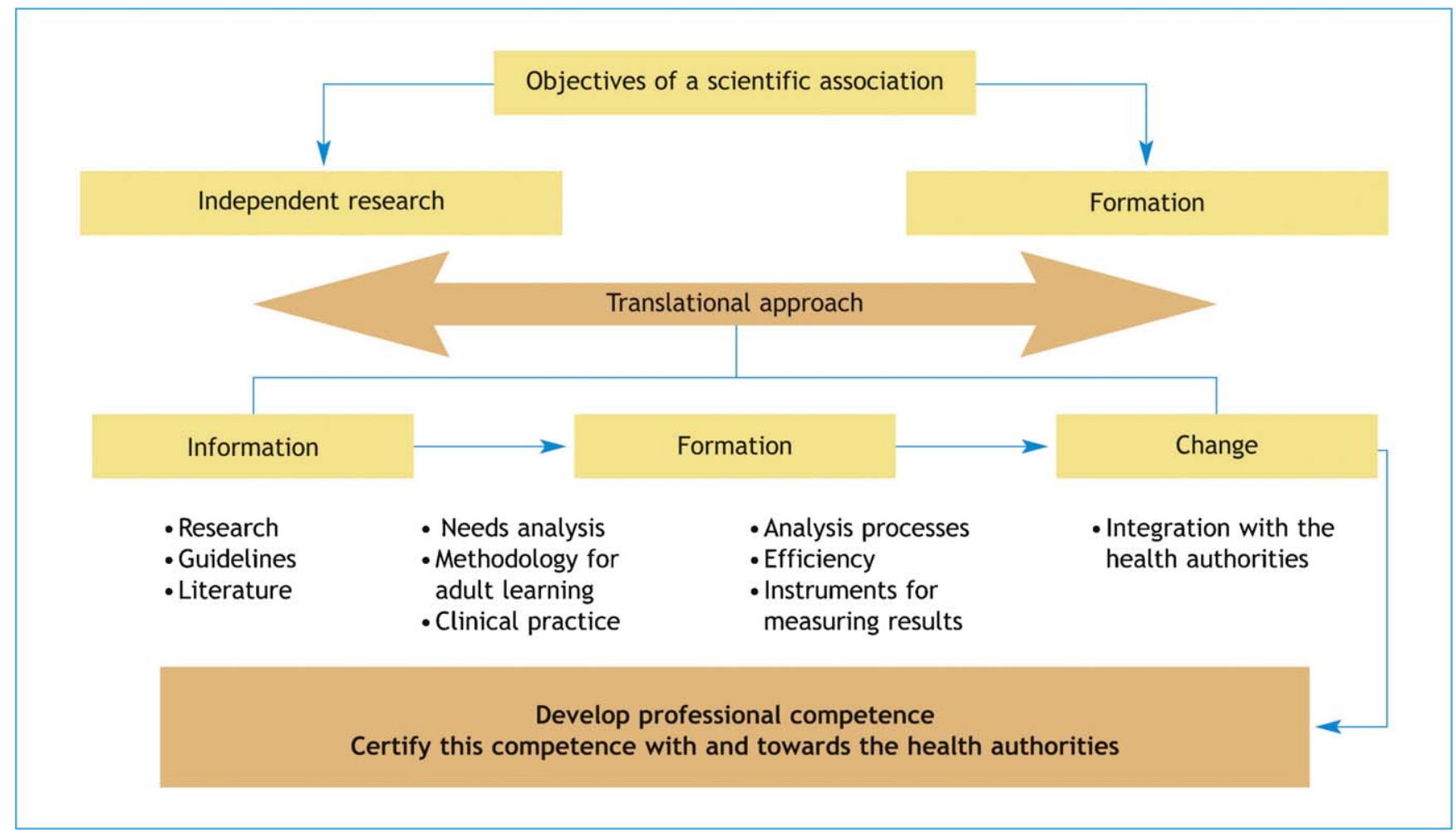

Figure 5 Objectives of a scientific association (Source: Fontanella A. 2010). 
Table 3 Basis and evaluation instruments of professional competence.

\begin{tabular}{|c|c|c|}
\hline Basis of evalutation & Notes & Instruments of evalutation \\
\hline Results (outcome) & $\begin{array}{l}\text { Evaluation is problematic; too many factors } \\
\text { influence the results and the outcome of the } \\
\text { treatment of the patient, especially if } \\
\text { complicated }\end{array}$ & \multirow{3}{*}{$\begin{array}{l}\text { - Hospital charts } \\
\text { - Administrative data } \\
\text { - Diaries/registers } \\
\text { - Direct observation }\end{array}$} \\
\hline Process/subprocess of treatment $^{a}$ & $\begin{array}{l}\text { Adherence of the physician to the guidelines } \\
\text { and/or diagnostic therapeutic paths defined as } \\
\text { standard of assistance in the process/subprocess } \\
\text { of patient treatment is evaluated }\end{array}$ & \\
\hline Volume of activity & The procedures carried out are evaluated & \\
\hline
\end{tabular}

medicine can be extended to specialistic competence otherwise not available at this site. It follows that the formulation of the portfolio (with evaluation of individual professional competence) will have to be adapted to the organisational context and its characteristics. The path of professional development of the individual medical director will have to refer to these differences and the dishomogeneity present in the National Health Service so as to contextualise the evaluating actions in a manner consistent with the specific existing reality. Also for this reason, it will be indispensable to program and realise extended experimentation of the system for evaluating clinical competence in different organisational realities located all over the national territory with the aim of verifying the applicability and utility of the proposed system in the field.

\section{Defining the path of professional development congruent to the formative objectives}

One of the "reasons to exist" of a Scientific Association is that of providing efficacious "training", useful for developing professional competence (Fig. 6).

The "grid" proposed, if nothing else, has the implicit advantage of defining the formative objectives of the hospital specialist in internal medicine. The details are explicit, according to a modulation which can proceed for the different items both in different nosological spheres (the "lines" in the grid) and for differentiated increasing specialised levels (the "columns"). The best didactic

Table 4 Modality of evalutation of professional competence (from [4-15]).

\section{Written evaluation test (evalutation of knowledge)}

- Multiple-choice quiz (true-false)

- The best of 5 multiple-choice quizzes

- Pairing of multiple options

- Written test

- Composition (editing, dissertation) allows the evaluation of knowledge but also the capacity of analysis, synthesis, written expresssion

- Key feature problems

- Self-evaluation by means of a check list or semiquantative questionnaires

\section{Evaluation in the field by a supervisor}

- Relational and cognitive testing:

- resoluton and discussion of clinical cases, review of research,

- review of clinical incidents, didactic capacity

- exploring the clinical reasoning regatrding a patient

- evaluating the capacity for communication and interaction in a professional group

- Body language testing: direct observation of carrying out procedures:

o to evaluate the knowledge, practical and procedural ability and the attitude of the physician in interaction with the patient

- Relational testing: role play

o to evaluate the management of nervous tension, reactivity and capacity of adaptation.

- Direct observation at the "bed-side" or with simulation at a distance/video or with control of the process of assistance and treatment by means of the use of:

- evaluation grids

- check lists

- "blueprint" assessment

- Macro-microsimulation- skill trainer 
Table 4 (Continued)

\begin{tabular}{|c|c|}
\hline Written evaluation test (evalutation of knowledge) & Evaluation in the field by a supervisor \\
\hline \multicolumn{2}{|l|}{$\begin{array}{l}\text { Practical testing (evaluation of ability): } \\
\text { Some of the methods proposed }\end{array}$} \\
\hline \multicolumn{2}{|l|}{$\begin{array}{l}\text { - OCSE (Objective Structured Clinical Examination) }{ }^{\text {a }} \\
\text { o OSPE; OSVE, OSTE, OSLER, etc. } \\
\circ \text { PACES [16] }\end{array}$} \\
\hline Evaluation of: & Instruments \\
\hline Knowledge & $\begin{array}{l}\text { - Multiple choice questionnaires (MCQ) } \\
\text { - Essays } \\
\text { - Short answers } \\
\text { - OCSE }\end{array}$ \\
\hline Ability (skills) - case management & $\begin{array}{l}\text { - Direct observation } \\
\text { - Audit } \\
\text { - Case reviews or Case Based Discussion } \\
\text { - Simulation } \\
\text { - DOPS [17]: Directly Observed Procedural Skills } \\
\text { - Procedure-based Assessment } \\
\text { - Portfolio [18,19] of individual competence } \\
\text { - Mini-CEX [20]: Mini Clinical Evaluation Exercise }\end{array}$ \\
\hline Attitude & $\begin{array}{l}\text { - Supervision and reporting } \\
\text { - Structured Peer review or Peer Assessment Tool } \\
\text { - Observation-direct or videotaped } \\
\text { - Perceived quality }\end{array}$ \\
\hline
\end{tabular}

\begin{abstract}
a The Objective Structured Clinical Examination (OSCE) is a method of approach for objective evaluation - planned and structured - of clinical competence with its various components. It is actually an organising scheme which permits the evaluation of various abilities but means of standardised and objective testing. OSCE was founded in 1975 by Ronald Harden of the Scottish University of Dundee. Over the years, numerous studies carried out in many countries have confirmed the objectivity, validity and reliability of this method in evaluating the clinical competence of students studying for a degree in medicine. OSCE was then developed, in particular, in those countries in which training was at an advanced level (Canada, United States, England, Australia, South Africa). With modified versions, it then spread to other health professions such as nurses, physiotherapists, dieticians and radiological technicians. It consists of a set of tests (stations) which must be passed by the candidate who, at each station, has to demonstrate what he is capable of doing, faced with a simulated patient or situation, rather than responding to theoretical questions. In OSCE, the evaluation criteria are predefined for each of the stations to pass, corresponding to specific clinical competence and the opinions are expressed, referring to specific evaluation grids, prepared in advance, ad hoc, according to the performance which has to be explored. In OSCE, therefore, some phases preliminary to the evaluation process itself are necessary: a) the definition of the core competences to be evaluated; b) the design and development of the testing (stations) and c) the planning and organisation of the stations. The number of stations is related to the competence to be evaluated, having a range from a minimum of 10 to a maximum of 25 stations. The time available for the candidate is usually pre-established and limited, a maximum of 10 minutes for the more complex tests, on the basis of the fact that, in real situations, time is always limited. Other instruments of evaluation were added to the OSCE which were, in fact, variants of this: OSLER: objective structured long examination record; OSPE: objective structured practical examination; OSVE: objective structured video examination; OSTE: objective structured teaching evaluation; OSPRE: objective structured performance-related examination; OSSE: objective structured selection exam.

$\mathrm{b}$ Direct observation of procedural competence (DOPS) is the observation and evaluation of a procedural ability carried out on a real patient. Procedural competence (technical or practical abilities) evaluated on the basis of DOPS vary from those which are relatively simple and common (such as taking a blood sample) to those which are more complex (e.g. endoscopic retrograde colangiopancreatography). The evaluation is carried out by an expert physician utilising a list of items and definite tasks, with a rating scale (e.g. below expectations, 1-2; borderline, 3; within expectations, 4; above expectations, 5-6).

c The portfolio is an instrument prevalently proposed for nurses. It consists of the collection of statementswhich demonstrates the continuous acquisition of ability, knowledge, attitude, comprehension and results obtained. In it, evidence, usually written, regarding the learning process, attesting to the achievement of objectives of personal and professional development are collected. It includes not only the curriculum vitae, but also a grid of self-evaluation to pursue and/or maintain professional competence.
\end{abstract}

instruments, the strategies and the operative contexts with which to implement the teaching/learning experiences will have to be defined (didactic lessons, face-to-face lessons with debates between the learner and the experts, round tables with debates, technical demonstrations, discussion of problems or didactic cases, films, questionnaires, didactic cases, stimulus flashes, direct execution (simulations) of practical or technical activity on the part of the participants, role playing, work in small groups, etc.).

\section{Defining the path of validation and certification}

The process of evaluation is integrated with other elements, represented by validation, accreditation and certification (Table 5).

It is necessary to distinguish certification from evaluation of the results. Evaluation is the expression of a judgment 


\section{The five levels of evaluation}

\begin{tabular}{|c|c|c|c|c|}
\hline & & \multicolumn{3}{|c|}{ Focus on world of work } \\
\hline \multicolumn{3}{|c|}{ Focus of instruction and formation } & & \\
\hline 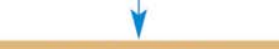 & $\downarrow$ & $\nabla \nabla$ & 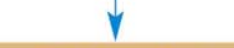 & $\downarrow$ \\
\hline $\begin{array}{l}\text { EVALUATION } \\
\text { Reactions } \\
\text { Satisfaction }\end{array}$ & $\begin{array}{l}\text { EVALUATION } \\
\text { Learning }\end{array}$ & $\begin{array}{l}\text { EVALUATION } \\
\text { Competences }\end{array}$ & $\begin{array}{l}\text { EVALUATION } \\
\text { Behaviour } \\
\text { at work } \\
\text { (transfer) }\end{array}$ & $\begin{array}{l}\text { EVALUATION } \\
\text { Organisational } \\
\text { impact }\end{array}$ \\
\hline $\begin{array}{l}\text { Degree of satisfaction } \\
\text { and about what }\end{array}$ & $\begin{array}{c}\text { What and } \\
\text { how much learned } \\
\text { (knowledge, capacity, etc.) }\end{array}$ & $\begin{array}{l}\text { How much of that } \\
\text { learned is expressed } \\
\text { in efficacious services } \\
\text { at the end of training }\end{array}$ & $\begin{array}{l}\text { In what measure } \\
\text { the behaviour } \\
\text { is effectively } \\
\text { transferred to the } \\
\text { work context }\end{array}$ & $\begin{array}{l}\text { Extent to which } \\
\text { this "new" behaviour } \\
\text { improves hospital results } \\
\text { and/or the environment } \\
\text { (climate, relationships, } \\
\text { etc.) }\end{array}$ \\
\hline
\end{tabular}

Figure 6 The levels of evalutation.

founded on elements furnished by the verification process which, in turn, is founded on the results of various measurements. Therefore, evaluation represents the result of a complex itinerary. Instead, certification of a competence is the representation of the intentional know how and efficacy reached by the professional described in relation to the context. The affirmation of the competences, expressed in the portfolio, therefore constitutes an added value with respect to individual evaluation. Certification is important since it is useful in defining how much and how to mobilise and make the most of one's knowledge, capacity and personal resources in order to respond efficaciously (finding an positive point of equilibrium between oneself and the organisation) to questions, expectations and requirements which the work context expresses. FADOI, as a scientific association accredited as a training provider, can even now exercise a significant role in the development of the learning and medical-scientific knowledge of the internist; at the same time, it can also be involved by the institutional bodies in accreditation of the different processes of evaluation, validation and certification, with evident advantages for the individual professional but also for the quality of the formation and the improvement of the institutional context (Table 6).

\section{Unresolved problems and conclusions}

It is evident that the work carried out in the last few months constitutes an indispensable premise, exactly because it is impossible to "credit" or "certify" competence without having first constructed a standard reference curriculum. The definite axes with the grid proposed of the competences (which - moreover - will have to undergo "maintenance" over time) constitute "the fabric" for the construction of paths of learning-formation, oriented to the acquisition of the key competences of the specialist in internal medicine and for the activation of a virtual circle of improvement of clinical practice.

Until now, the work carried out is therefore only partial and exclusively represents the beginning of a long and

Table 5 Processes of verfication of professional knowledge.

\begin{tabular}{ll}
\hline Evaluation & $\begin{array}{l}\text { Process through which the attribution of a judgment of value is reached with respect to the competences } \\
\text { acquired, possessed, practised }\end{array}$ \\
\hline Validation & $\begin{array}{l}\text { Process through which the experience arrived at by the professional is reconstructed, documented } \\
\text { and described in terms of competence and then compared to institutionally-defined professional standards }\end{array}$ \\
\hline Accreditation & $\begin{array}{l}\text { Process through which an agency or a public or private institution "enables" a person to demonstrate that } \\
\text { he/she possesses the competences declared, namely taking a qualifying exam in front of a commission }\end{array}$ \\
\hline Certification & $\begin{array}{l}\text { Process through which the competences acquired by a person in a formal, informal or non-formal context are } \\
\text { verified by means of specific tests, relating to professional standards, institutionally defined and recognised } \\
\text { publically: } \\
\text { - aimed at the recognition of formative and professional credits usable in many contexts at the } \\
\text { national level } \\
\text { - results of a path of "validation" on the part of an agency called to recognise the "credits" } \\
\text { presented legally and socially } \\
\text { - reached following verification on the part of an expert commission }\end{array}$ \\
\hline
\end{tabular}


Table 6 The convenience levels of a professional evaluation process.

\begin{tabular}{ll}
\hline & \multicolumn{1}{c}{ Advantages of an evaluation path } \\
\hline For the patient & - transparency \\
& - objective elements of evaluation \\
\hline - overcoming self-referentiality \\
\hline - better identification and exploitation of one's professional competence \\
- self-analysis of one's strong and weak points of additional formative/professional development \\
- overcoming self-referentiality \\
- elaboration of a congruent and realistic professional project, oriented to specific objectives \\
- (re)motivation, (re)orientation, increate self-esteem/trust (empowerment) \\
- reinforcement to transfer of the competence acquired (mobility) \\
- additional development of one's competence (méta-cognition) \\
- improvement of the quality of the curriculum \\
\hline - qualitative improvement of the offer and transparency of the training \\
- increase in the efficiency and efficacy of the training offered \\
- personalisation/individualisation/modulation of the formative intervention/participation \\
- recognition of credits (also for additional "modules") \\
\hline - exploitation of human resources and better knowledge of people \\
- better professional quality guaranteed to citizens and transparency \\
- optimisation of career management \\
- greater efficacy/efficiency in selection/incentive processes \\
- facilitation of change \\
- facilitation of adaptation of people to organisational evolution \\
- selection of formative investments
\end{tabular}

complex path. It is necessary to put experimentation of the evaluative model into actual practice in the organisational structures with the aim of verifying the applicability "in vivo", perfecting the instruments utilised and correcting eventual errors or omissions.

However, the commitment to overcome any possible discrepancy between "evaluation of competence" and "programming for competence" remains. The next challenges awaiting us regard some still ongoing problems on which it will be necessary, as was done for the sharing of the grid of the competences, to find the widest consensus, both inside FADOI and with other institutional interlocutors. There are numerous ongoing problems which remain, such as, for example:

1. willingness (or not) of access to evaluation/certification;

2. practical modalities of evaluation;

3. degrees of learning/certification;

4. minimum standards required for certification

5. levels of certification

6. methods of certification of competence;

7. identification of the certifiers;

8. legal value of certification;

9. when to certify and with what deadline;

10. implications for the development of the career path for the specialist in internal medicine.

The questions to face in the near future are, substantially, numerous and complex. With additional constructive criticism, integrative proposals and/or emendation and the commitment of everyone, together, we will do it.

\section{References}

[1] ASFOR - Associazione Italiana per la formazione manageriale, Glossario, tratto da Rivista dell'Associazione Italiana per la
Formazione Manageriale, anno XVIII - Supplemento al n. 1/ 2006, http://www.asfor.it/sitonuovo/LETTERA\%20ASFOR/ Asfor_Glossario_2006.pdf.

[2] Bezzi C, Glossario della ricerca valutativa, Versione 5.1.1. del 28 Maggio 2009, http://www.valutazione.it/PDF/Glossario. pdf.

[3] Norcini JJ. ABC of learning and teaching in medicine, Work based assessment. BMJ 2003;326:753-5.

[4] Harden RM, Stevenson M, Downie WW, Wilson GM. Assessment of clinical competence using objective structured examination. Br Med J 1975;22:447-51.

[5] Harden RM. What is an OSCE? Medical Teacher 1988;10(1): $19-22$.

[6] Wass V, van der Vleuten C, Shatzer J, Jones R. Assessment of clinical competence. Lancet 2001;357:945-9.

[7] Schuwirth LWT, van der Vleuten CPM. C of learning and teaching in medicine: Written assessment. BMJ 2003;326:643-5.

[8] Schuwirth LWT, van der Vleuten CPM. Different written assessment methods: what can be said about their strengths and weaknesses? Medical Education 2004;38:974-9.

[9] Chiantor L, Dimonte V, Garrino L, Renga G. L'objective structured clinical examination: analisi della letteratura. Tutor 2007;7/3:174-84, http://www.cse.it/riviste/Archivio_Tutor/ 2007/Tutoronline3.pdf.

[10] Smee S. ABC of learning and teaching in medicine: skill based assessment. BMJ 2003;326:703-6.

[11] Weissman JS, Betancourt JR, et al. Resident Physicians' Preparedness to Provide Cross-Cultural Care. Journal of the American Medical Association 2005;1058-67.

[12] Gome JJ, Paltridge D, Inder WJ. Review of intern preparedness and education experiences in General Medicine. Internal Medicine Journal 2008;38:249-53.

[13] Lenhard A, Moallem M, Marrie RA, Becker J, Garland A. An intervention to improve procedure education for internal medicine residents. J Gen Intern Med 2008;23(3):288-93.

[14] Task Force dell'EuSEM sul Curriculum approvato dal Council della Società Europea per la Medicina d'Emergenza e dalla 
Commissione Multidisciplinare in medicina d'Emergenza della UEMS Curriculum Europeo per la Medicina d'Emergenza, Un documento della, Curriculum Committee Chair: Roberta Petrino, Italy, http://www.simeu.it/download/ct/Specializzazione/Curriculum_EuSEM_it.pdf.

[15] Wigton RS. Procedural Skills for Internal Medicine: A New Program to Help Internists Build And Assess Clinical Competence Reference Manual. Mosby Inc; 1996.

[16] PACES MRCP(UK) Examination Website http://www.mrcpuk. org/Pages/Home.aspx.

[17] Wigton RS. Measuring procedural skills. Annals of Internal Medicine 1996;125:1003-4.

[18] Brown R. Portfolio development and profiling for nurses, $2^{\text {nd }} E d$, Dinton, UK: Quay; 1995.

[19] McMullan M, Endacott R, Gray MA, Jasper M, Miller CML, Scholes J, Webb C. Portfolios and assessment of competence: a review of the literature. Journal of Advanced Nursing 2003; 41(3):283-94.
[20] Norcini JJ, Blank LL, Duffy FD, Fortna GS. The Mini-CEX: A Method for Assessing Clinical Skills. Ann Int Med 2003;138/ 6:476-81.

\section{Further reading}

1. Bellis P. Progetto Minerva: origini, obiettivi, metodologie. In: Medicina Interna: Complessità e metodologia $\mathrm{n}^{\circ}$ 3. Torino: CSE; 2004.

2. Mc Clelland DC. Testing for competence more than intelligence. American Psychologyst 1973;28/1:1-14.

3. Spencer LM, Spencer SM. Competenza nel lavoro. Milano: Franco Angeli; 1995.

4. Dalkey N, Helmer O. An Experimental Application of the Delphi Method lo the use of Experts. Management Science 1963;9/3: 458-67.

5. Fontanella A, Presentazione del Dipartimento Formazione, Fondazione FADOI, Roma 3 marzo 2010. 


\section{Legend of abbreviations and acronyms}

$A B C D-A B C D 2:$ Age, Blood pressure, Clinical features, Duration of symptoms and Diabetes

$A B I$ (o ABPI) Index: Ankle Brachial (Pressure) Index

ABPM: Ambulatory blood pressure monitoring

$A C D$ : Anaemia of chronic disease

ACE: Angiotensin converting enzyme

AchEls: Acetylcholine-esterases

ACLS: Advanced cardiovascular life support

ACR: Albumin-creatinine ratio

ACS: Acute coronary syndrome

AD: Alzheimer's disease

ADH: Antidiuretic hormone

ADL: Activity of daily living

ALP: Alkaline phosphatase

ADR: Adverse drug reaction

AF: Atrial fibrillation

AH: Arterial hypertension

AMA: Anti-mitochondrial antibodies

AMI: Acute myocardial infarction

ANA: Antinuclear antibodies

AP: Acute pancreatitis

AP: Arterial pressure

APACHE: Acute physiology and chronic health evaluation

APR-DRG: All Patient Refined Diagnosis Related Groups

APS: Acute physiology score

ARDS: Acute respiratory distress syndrome

ARI: Acute renal insufficiency

ASA: American Society of Anesthesiologists

AVPU: Alert, Vocal, Pain, Unresponsive

BAP: Bone-specific alkaline phosphatase

BAL: Bronco-alveolar lavage

BEE: Basal Energy Expenditure

BISAP: Bedside index for severity in acute pancreatitis

BMD: Bone mineral density

BMI: Body Mass Index

BNP: Brain Matriuretic Peptide

BODE (index): Body-Mass Index, Airflow Obstruction, Dyspnea, Exercise Capacity Index

BOOP: Bronchiolitis obliterans organizing pneumonia

BSA: Bedside swallowing assessment
BTS: British Thoracic Society

CAD: Coronary artery disease

CAM: Confusion Assessment Method

CAP: Community-acquired pneumonia

CIN: Contrast-induced nephropathy

CIRS: Cumulative Illness Rating Scale

CD SHOCK: Cardioverter-Defibrillator shock

CHA2-DS2-VASc: Congestive heart failure, Hypertension,

Age $\geq 75$ years (doubled), Diabetes mellitus, Stroke

(doubled), Vascular disease, Age 65-74 years, Sex category

CKD-EPI: Chronic Kidney Disease Epidemiology Collaboration

CJD: Creutzfeldt-Jacob disease

CME: Continuing Medical Education

CNS: Central nervous system

CNS: Canadian Neurological Score

CSS: Canadian stroke scale

COPD: Chronic obstructive pulmonary disease

CP: Chronic pancreatitis

CRI: Chronic renal insufficiency

CRP: C-reactive protein

CS: Cardiogenic shock

CSF: Cerebrospinal fluid

CT: Computed tomography

CUS: Compression ultrasonography

CV: Cardiovascular

CVC: Central vein catheter

CVP: Central venous pressure

DEXA: Dual energy X-ray absorptiometry

DFO: Deferoxamine

DIC Score: Disseminated Intravascular Coagulation Score

DKA: Diabetic Ketacidosis

DM: Diabetes mellitus

DNI: Diabetic Neuropathy Index

DOPS: Direct Observation of Procedural Skills

DRS: Delirium Rating Scale

DSI: Delirium symptom interview

DSM: Diagnostic and Statistical Manual of Mental Disorders

DVT: Deep venous thrombosis

DXA: Dual-energy X-ray Absorbiometry

EAL: Essential assistance levels 
EBM: Evidence based medicine

ECF: Extracellular corporeal fluid

ECG: Electrocardiogram

EGDS: Esophagogastroduodenoscopy

Ehra: European Heart Rhythm Association

EBM: Evidence-based medicine

EEG: Electroencephalogram

EFIM: European Federation of Internal Medicine

EH: Essential hypertension

EHRA: European Heart Rhythm Association

EH: Essential hypertension

EPA: Acute pulmonary edema

EPO: Eritropoietine

ERCP: Endoscopic retrograde cholangiopancreatography

ETOH: Alcohol and alcohol abuse

EUS: Endoscopic ultrasonography

EWSS: Early Warning Scoring System

FEV1: Forced expiratory volume in the 1st second

FIM: Functional Independency Measurement scale

Fine Port for CAP: Fine.Port criteria for Community acquired pneumonia

FRAX: (WHO) Fracture Risk Assessment Tool

FUO: Fever of unknown origin

GFR: Glomerular filtration rate

GCS: Glasgow Coma Scale

G-CSF: Granulocyte-colony stimulating factor

GFV: Glomerular filtration velocity

GM-CSF: Granulocyte-macrophage colony stimulating factor

GOLD: Global Initiative for Chronic Obstructive Lung Disease

GRACE: Global Registry of Acute Coronary Events

HAS-BLED: Hypertension, Abnormal renal/liver function,

Stroke, Bleeding history or predisposition, Labile international normalized ratio, Elderly ( $>65$ years), Drugs/alcohol

concomitantly

$\mathrm{Hb}$ : Haemoglobin

HBSAg: Hepatitis B surface antigen

HBV: Hepatitis B virus

HCV: Hepatitis $C$ virus

HDR: Hospital discharge record

HHS: Non-ketotic hyperosmolarity

HLA: Human leukocyte antigen

HIT: Heparin induced thrombocytopenia

HIV: Human Immunodeficiency Virus

HSC: Haemopoietic stem cells

HSS: Hyperosmolar hyperglycaemic syndrome

HVPG: Hepatic venous portal gradient

IADL: Instrumental activity of daily living

IBD: Inflammatory bowel disease

ICD: Implantable cardioverter-defibrillator

ICD: International Classification of Diseases

ICF: Intracellular corporeal fluid

IMT: Intima-medial thickness

INR: International Normalised Ratio

IPSS: International Prognostic Scoring System

IVC: Inferior vena cava

LACS: Lacunar stroke

LES: Lupus eritematoso sistemico

LKM: Liver-kidney microsomal antibodies

LOD: Logistic Organ Dysfunction system

LVAD: Left ventricular assist device

LVEF: Left ventricular ejection fraction

MAOI: Monoamine oxidase inhibitors
MAP: Mean arterial pressure

MARDS: Montgomery-Åsberg Depression Rating Scale

MCD: Mild cognitive dysfunction

MCID: Minimal clinically important difference

MCQ: Multiple choice questionnaire

MCT: Medium chain triglycerides

MDAS: Memorial Delirium Assessment Scale

MDE: Multidimensional evaluation

MDRD: Modification of diet in renal disease

MDS: Mielodysplastic syndrome

MEVS: Maximum expiratory volume in 1st second

MEWS: Modified early warning score

MID: Multi-infarct dementia

MINI-CEX: Mini Clinical Evaluation Exercise

MINI-PAT: Mini-Peer Assessment Tool

MID: Minimally important difference

MMS: Mini Mental state

MNA: Mini nutritional assessment

MOF: Multiple organ failure

MPM: Mortality prediction model

MRCP: Magnetic resonance cholangiopancreatography

MRCP-UK: Membership of the del Royal College of Physicians

MRX: Morphometric Radiography

MSF: Multi-Source Feedback

MUST: Malnutrition screening tool

MXA: Morphometric X-ray Absorptiometry

NARI: Noradrenaline reuptake inhibitor

NASSA: Noradrenergic and specific serotoninergic

antidepressants

NIEC: North Italian Endoscopic Club

$\mathrm{NIH}$ : National Institutes of Health

NIHSS: NIH Stroke Scale

NIV: Non-invasive ventilation

NKF-KDOQI: US National Kidney Foundation Kidney

Disease Outcomes Quality Initiative

NMR: Nuclear magnetic resonance

NRI: Nutritional Risk Index

NRS: Nutritional Risk Screening

NSAIDS: Non-steroid anti-inflammatory drugs

NSF: Nephrogenic systemic fibrosis

NSRI: Noradrenaline and seratonin reuptake inhibitor

NSTEMI: Non-ST segment elevation myocardial infarction

NYHA: New York Heart Association

OAT: Oral anticoagulant therapy

OBRI: Outpatient bleeding risk index

OCSP: Oxfordshire Community Stroke Project

OPG: Osteoprotegerin (or OCIF: osteoclastogenesis inhibitory factor)

O.P.Q.R.S.T.: $\mathrm{O}=$ Onset $\mathrm{P}=$ Provokes; $\mathrm{Q}=$ Quality;

$\mathrm{R}=$ Radiates $; \mathrm{S}=$ Severity

OSCE: Objective Structured Clinical Examination

OSLER: Objective structured long examination record

OSPE: Objective structured practical examination

OSVE: Objective structured video examination

OSPRE: Objective structured performance-related

examination

OSSE: Objective structured selection exam

OSTE: Objective structured teaching evaluation

OSVE: Objective structured video examination

OTI: Orotracheal intubation

OU: Operative Unit

PACCS: Partial anterior circulation stroke 
PACES: Practical assessment of clinical examination skills

PACS: Partial anterior circulation stroke

PAD: Peripheral arterial disease

PAI: Percutaneous acetic acid injection

PAPs: Pulmonary arterial pressure

PBC: Primary biliary cirrhosis

PCR: Polymerase chain reaction

PDS: Progressive Deterioration Scale

PEI: Pancreatic exocrine insufficiency

PEEP: Positive end-expiratory pressure

PEG: Percutaneous endoscopic gastrotomy

PEM: Protein energy malnutrition

PET: Positron emission tomography

PICC: Peripherally inserted central catheter

PICO Method: Patient, Intervention, Comparison, Outcome

PICP: Procollagen type I C-terminal peptide

PINP: Procollagen type I N-terminal propeptide

POCS: Posterior circulation stroke

PM: Pacemaker

P.Q.R.S.T.: $\mathrm{P}=$ Provokes; $\mathrm{Q}=$ Quality; $\mathrm{R}=$ Radiates;

$\mathrm{S}=$ Severity

PSC: Primary sclerosing cholangitis

PSI: Physiology stability index

PST: Papilla sphincterotomy

PTH: Parathyroid hormone

PURSUIT: Platelet glycoprotein Ilb/IIla in unstable

angina: Receptor suppression using Integrilin

PVC: Premature ventricular contractions

QCT: Quantitative Computed Tomography

QUS: Quantitative Ultrasonography

RANK: Receptor Activator of Nuclear Factor

к B (TRANCE Receptor)

RANKL: Receptor activator of nuclear factor kappa-B ligand

RDNR: Recommended daily nutritional requirements

RF: Radiofrequency

RFI: Renal Failure Index

$r$-HU EPO: Recombinant erthyropoietin

SAPS: Simplified Acute Physiological Score

SAT: Supra-aortic trunks
SAPS: Simplified Acute Physiology Score

SCA: Sudden cardiac arrest

SH: Secondary hypertension

SERMs: Selective estrogen receptor modulators

SIADH: Syndrome of inappropriate antidiuretic

hormone

SIRS: Systemic inflammatory response syndrome

SLE: Systemic lupus erythematosus

SMA: Smooth muscle antibody

SOFA: Sepsis-related Organ failure assessment;

SPECT: Single photon emission computed tomography

SPREAD: Stroke prevention and educational awareness diffusion

SSRI: Selective serotonin reuptake inhibitor

SSS: Scandinavian Stroke Scale

STEMI: ST segment elevation myocardial infarction

TAB: Team assessment behaviour

TACE: Transarterial chemoembolisation

TACS: Total anterior circulation stroke

TAE: Transarterial embolisation

TAP: Trypsin activation peptide

TAPSE: Tricuspid annular plane systolic excursion

TEE: Transesophageal ecocardiography

TEN: Total enteral nutrition

TPN: Total parenteral nutrition

TIA: Transient ischemic attack

TIMI: Thrombolysis in myocardial infarction

TIPS: Trans-jugular Intrahepatic Porto-systemic Shunt

TISS: Therapeutic intervention scoring system

TPH: Thromboembolic pulmonary hypertension

VD: Vascular dementia

VEMS: Virtual Expert Mass Spectometrist

VINDICATE: Vascular, Infections, Nutrition, Drugs, Injury,

Cardiac, Autoimmune, Tumors, Endocrine

VTE: Venous thromboembolism

WFNS: World Federation of Neurological Surgeons

WHO: World Health Organisation

WHVPG: Wedged hepatic venous portal gradient

WPSS: WHO classification-based Prognostic Scoring System 


\section{References}

\section{General characteristics of the health practitioner}

- Cocco GC. Valorizzare il capitale umano d'impresa. Il talento delle persone come competenza distintiva delle imprese. Milano: Etas, 2001.

- Cortellazzi S, Pais I. Il posto della competenza. Persone, organizzazioni, sistemi formativi. Milano: Franco Angeli, 2001.

- Fertonani M. Le competenze manageriali. Dalla valutazione delle prestazioni e del potenziale alla valutazione delle competenze manageriali. Milano: Franco Angeli, 2003.

- Spencer LM, Spencer SM. Competenza nel lavoro. Modelli per una performance superiore. Milano: Franco Angeli, 2003.

\section{Training required for the hospital physician specialised in Internal Medicine}

- Fauci AS, Braunwald E, Kasper DL, Hauser SL, Longo DL, Jameson JL, et al (eds). Harrison - Principi di medicina interna. $17^{\mathrm{a}}$ Ed. Milano: McGraw-Hill, 2009.

- Forrest CB. A typology of specialists' clinical roles. Arch Intern Med 2009;169(11):1062-8.

- Kellett J, Vanderschueren S. What is internal medicine? Eur J Intern Med 2007;18(7):509.

- Kucharz EJ. Internal medicine: yesterday, today, and tomorrow. Part II. Definition and development in the 20th century. Eur J Intern Med 2003;14(4):272-4

- Portioli I. Vita da internista. It J Med 2010;4(4):217.

- Royal College of General Practitioners. Curriculum Home. http: / / www.rcgp-curriculum.org.uk/nmrgcp/wpba/ multi-source_feedback.aspx
Training required: individual behaviours of the hospital physician manager specialised in Internal Medicine

- Conti A, Gensini GF. Medicina basata sulle evidenze e linee guida. Tavola rotonda "e-Health, prospettive a livello nazionale ed europeo". 2004.

- Corrao S, Fontana S. Governo clinico, miglioramento della performance e ruolo dell'internista. G It Medicina Interna 2003;2(2):4-8.

- Goodman CS. HTA 101: Introduction to Health Technology Assessment. The Lewin Group. January 2004

- Impact of HTA in policy and practice. The experiences of the INAHTA agencies. http://www.inahta.org/inahta_ web/index.asp

- NIHR Health Technology Assessment programme. http:// www.ncchta.org/index.htm

- Scottish Intercollegiate Guidelines Network. SIGN guidelines: an introduction to SIGN methodology for the development of evidence-based clinical guidelines. Edinburgh: SIGN Publication N. 39. SIGN Secretariat. Royal College of Physicians of Edinburgh. 1999.

\section{Management of the complex patient}

- Nardi R, Fabbri T, Belmonte G. Medicina interna, paziente complesso, evidence-based medicine e le non evidenze. It J Med 2009;3(4):191-200

- Nardi R, Scanelli G, Borioni D, Grandi M, Sacchetti C, Parenti $M$, et al. The assessment of complexity in internal medicine patients. The FADOI Medicomplex Study. Eur J Intern Med 2007;18(4):283-7.

- Nardi R, Scanelli G, Corrao S, Iori I, Mathieu G, Cataldi Amatrian R. Co-morbidity does not reflect complexity in internal medicine patients. Eur J Intern Med 2007;18(5): 359-68. 
- Panaszek B, Machaj Z, Bogacka E, Lindner K. Chronic disease in the elderly: a vital rationale for the revival of internal medicine. Pol Arch Med Wewn 2009;119(4): 248-54.

- Pedace C, Nardi R, Mathieu G. Disease management in medicina interna. Malattie croniche e continuità assistenziale. Torino: Centro Scientifico Editore, 2004.

- Rambihar VS, Rambihar VS. Complexity: the science for medicine and the human story. Lancet 2010;375(9721): 1162.

- Safford MM, Allison JJ, Kiefe Cl. Patient complexity: more than comorbidity. the vector model of complexity. J Gen Intern Med 2007;22 Suppl 3:382-90.

\section{Frail and "difficult" patients}

- Bernabei R, Landi F, Gambassi G, Sgadari A, Zuccala G, Mor $\mathrm{V}$, et al. Randomised trial of impact of model of integrated care and case management for older people living in the community. BMJ 1998;316(7141):1348-51.

- Bernabei R, Venturiero V, Tarsitani P, Gambassi G. The comprehensive geriatric assessment: when, where, how. Crit Rev Oncol Hematol 2000;33(1):45-56.

- Consensus Development Panel, Solomon DH et al. Geriatric Assessment Methods for Clinical Decision Making. Health Services/Technology Assessment Text (HSTAT). http:// consensus.nih.gov/1987/1987GeriatricAssessment065html.htm

- Health and Public Policy Committee, American College of Physicians. Comprehensive functional assessment for elderly patients. Ann Intern Med 1988;109(1):70-2.

- Linee guida sull'utilizzazione della valutazione multidimensionale per l'anziano fragile nella rete dei servizi. Progetto finalizzato del Ministero della Sanità. ICS 110.1 RF 98.98.

- Nardi R, Scanelli G, Tragnone A, Lolli A, Kalfus P, Baldini A, et al. Difficult hospital discharges in internal medicine wards. Intern Emerg Med 2007;2(2):95-9.

- Wenger NS, Shekelle PG. Assessing care of vulnerable elders: ACOVE project overview. Ann Intern Med 2001;135(8 Pt 2):642-6.

\section{Critical patients}

- Armitage M, Eddleston J, Stokes T; Guideline Development Group at the NICE. Recognising and responding to acute illness in adults in hospital: summary of NICE guidance. BMJ 2007;335(7613):258-9.

- Bourdaud N, Carli P. Monitorage d'urgence. EMC-Médecine 2004;1:569-79.

- Bright D, Walker W, Bion J. Clinical review: Outreach - A strategy for improving the care of the acutely ill hospitalized patient. Crit Care 2004;8(1):33-40.

- Eagle KA, Brundage BH, Chaitman BR, Ewy GA, Fleisher LA, Hertzer NR, et al. Guidelines for perioperative cardiovascular evaluation for noncardiac surgery. Report of the American College of Cardiology/American Heart Association Task Force on Practice Guidelines. Committee on Perioperative Cardiovascular Evaluation for Noncardiac Surgery. Circulation 1996;93(6):1278-317.
- Knaus WA, Wagner DP, Draper EA, Zimmerman JE, Bergner M, Bastos PG, et al. The APACHE III prognostic system. Risk prediction of hospital mortality for critically ill hospitalized adults. Chest 1991;100(6):1619-36.

- Lemeshow S, Le Gall JR. Modeling the severity of illness of ICU patients. A systems update. JAMA 1994;272(13): 1049-55.

- NICE Clinical Guideline 50. Acutely III Patients in Hospital. Recognition of and response to acute illness in adults in hospital. http://guidance.nice.org.uk/CG50

- Task Force of the American College of Critical Care Medicine, Society of Critical Care Medicine. Guidelines for intensive care unit admission, discharge, and triage. Crit Care Med 1999;27(3):633-8.

\section{Severity scores (http://www.medalreg.com/)}

- APACHE III Physiologic Subscore

- CRITICAL CARE

- New Simplified Acute Physiology Score (SAPS II)

- Organ Failure Score

- The Omega Score

- The Rapid Acute Physiology Score (RAPS)

- The Sepsis-related Organ Failure Assessment (SOFA) Score

- TISS-28

Cardiovascular

- The National Registry of Myocardial Infarction Non-ST Elevation (NRMI NSTE) Risk Model for Mortality

- TIMI Risk Score in Patients with Unstable Angina or Non-ST Elevation Myocardial Infarction

Hepato-biliary pancreas

- The Child-Pugh Score for Grading Hepatic Cirrhosis

- CT Severity Index (Balthazar Score) in Acute Pancreatitis

- Glasgow Prognostic Criteria in Acute Pancreatitis (Imrie Criteria)

Gastro-intestinal

- The Rockall Risk Scoring System in Upper Gastrointestinal Bleeding

Neurology

- Clinical Examination Scale Following Acute Cerebral Infarction (NIH Stroke Scale, NIHSS)

- Glasgow Coma Scale

- Modified NIH Stroke Scale

- Rankin's Clinical Signs Associated with Poor Outcome After Stroke

- The Scandinavian Neurological Stroke Scale (SSS)

\section{Patients with acute coronary sindrome}

- Anderson JL, Adams CD, Antman EM, Bridges CR, Califf RM, Casey DE Jr, et al; American College of Cardiology; American Heart Association Task Force on Practice Guidelines (Writing Committee to Revise the 2002 Guidelines for the Management of Patients With Unstable Angina/Non ST-Elevation Myocardial Infarction); American College of Emergency Physicians; Society for Cardiovascular Angiography and Interventions; Society of Thoracic Surgeons; American Association of Cardiovascular and Pulmonary Rehabilitation; Society for Academic Emergency Medicine. ACC/AHA 2007 guidelines for the management 
of patients with unstable angina/non ST-elevation myocardial infarction: a report of the American College of Cardiology/American Heart Association Task Force on Practice Guidelines (Writing Committee to Revise the 2002 Guidelines for the Management of Patients With Unstable Angina/ Non ST-Elevation Myocardial Infarction): developed in collaboration with the American College of Emergency Physicians, the Society for Cardiovascular Angiography and Interventions, and the Society of Thoracic Surgeons: endorsed by the American Association of Cardiovascular and Pulmonary Rehabilitation and the Society for Academic Emergency Medicine. Circulation 2007;116(7):e148-304.

- Canadian Cardiovascular Society; American Academy of Family Physicians; American College of Cardiology; American Heart Association. 2007 focused update of the ACC/AHA 2004 guidelines for the management of patients with ST-elevation myocardial infarction: a report of the American College of Cardiology/American Heart Association Task Force on Practice Guidelines. J Am Coll Cardiol 2008;51(2):210-47.

- European Association for Percutaneous Cardiovascular Interventions; ESC Committee for Practice Guidelines. Guidelines on myocardial revascularization: The Task Force on Myocardial Revascularization of the European Society of Cardiology (ESC) and the European Association for Cardio-Thoracic Surgery (EACTS). Eur Heart J 2010;31(20):2501-55.

- Fox K, Garcia MA, Ardissino D, Buszman P, Camici PG, Crea F, et al; Task Force on the Management of Stable Angina Pectoris of the European Society of Cardiology; ESC Committee for Practice Guidelines (CPG). Guidelines on the management of stable angina pectoris: executive summary: The Task Force on the Management of Stable Angina Pectoris of the European Society of Cardiology. Eur Heart J 2006;27(11):1341-81.

- Fraker TD Jr, Fihn SD; 2002 Chronic Stable Angina Writing Committee; American College of Cardiology; American Heart Association. 2007 chronic angina focused update of the ACC/AHA 2002 guidelines for the management of patients with chronic stable angina: a report of the American College of Cardiology/American Heart Association Task Force on Practice Guidelines Writing Group to develop the focused update of the 2002 guidelines for the management of patients with chronic stable angina. J Am Coll Cardiol 2007;50(23):2264-74.

- Krumholz HM, Anderson JL, Bachelder BL, Fesmire FM, Finn SD, Foody JM, et al; American College of Cardiology/ American Heart Association Task Force on Performance Measures; American Academy of Family Physicians; American College of Emergency Physicians; American Association of Cardiovascular and Pulmonary Rehabilitation; Society for Cardiovascular Angiography and Interventions; Society of Hospital Medicine. ACC/AHA 2008 performance measures for adults with ST-elevation and non-ST-elevation myocardial infarction: a report of the American College of Cardiology/American Heart Association Task Force on Performance Measures (Writing Committee to develop performance measures for ST-elevation and nonST-elevation myocardial infarction): developed in collaboration with the American Academy of Family Physicians and the American College of Emergency Physicians: endorsed by the American Association of Cardiovascular and Pulmonary Rehabilitation, Society for Cardiovascular Angiography and Interventions, and Society of Hospital Medicine. Circulation 2008;118(24):2596-648.

- Kushner FG, Hand M, Smith SC Jr, King SB $3^{\text {rd }}$, Anderson JL, Antman EM, et al; American College of Cardiology Foundation/American Heart Association Task Force on Practice Guidelines. 2009 Focused Updates: ACC/AHA Guidelines for the Management of Patients With ST-Elevation Myocardial Infarction (updating the 2004 Guideline and 2007 Focused Update) and ACC/AHA/SCAl Guidelines on Percutaneous Coronary Intervention (updating the 2005 Guideline and 2007 Focused Update): a report of the American College of Cardiology Foundation/American Heart Association Task Force on Practice Guidelines. Circulation 2009;120(22):2271-306.

- Scottish Intercollegiate Guidelines Network. Acute Coronary Syndromes. http://www.sign.ac.uk/guidelines/ fulltext/93-97/index.html

- Task Force for Diagnosis and Treatment of Non-ST-Segment Elevation Acute Coronary Syndromes of European Society of Cardiology, Bassand JP, Hamm CW, Ardissino D, Boersma E, Budaj A, Fernández-Avilés F, et al. Guidelines for the diagnosis and treatment of non-ST-segment elevation acute coronary syndromes. Eur Heart J 2007;28(13): 1598-660.

- Van de Werf F, Bax J, Betriu A, Blomstrom-Lundqvist C, Crea F, Falk V, et al; ESC Committee for Practice Guidelines (CPG). Management of acute myocardial infarction in patients presenting with persistent ST-segment elevation: the Task Force on the Management of ST-Segment Elevation Acute Myocardial Infarction of the European Society of Cardiology. Eur Heart J 2008;29(23):2909-45.

\section{Patients with cardiac arrhythmias}

- Blomström-Lundqvist C, Scheinman MM, Aliot EM, Alpert JS, Calkins H, Camm AJ, et al; American College of Cardiology; American Heart Association Task Force on Practice Guidelines; European Society of Cardiology Committee for Practice Guidelines. Writing Committee to Develop Guidelines for the Management of Patients With Supraventricular Arrhythmias. ACC/AHA/ESC guidelines for the management of patients with supraventricular arrhythmias-executive summary: a report of the American College of Cardiology/American Heart Association Task Force on Practice Guidelines and the European Society of Cardiology Committee for Practice Guidelines (Writing Committee to Develop Guidelines for the Management of Patients With Supraventricular Arrhythmias). Circulation 2003;108(15):1871-909.

- Estes NA $3^{\text {rd }}$, Halperin JL, Calkins H, Ezekowitz MD, Gitman P, Go AS, et al; American College of Cardiology/American Heart Association Task Force on Performance Measures; Physician Consortium for Performance Improvement (Writing Committee to Develop Clinical Performance Measures for Atrial Fibrillation); Heart Rhythm Society. ACC/AHA/ Physician Consortium 2008 clinical performance measures for adults with nonvalvular atrial fibrillation or atrial flutter: a report of the American College of Cardiology/ American Heart Association Task Force on Performance Measures and the Physician Consortium for Performance 
Improvement (Writing Committee to Develop Clinical Performance Measures for Atrial Fibrillation): developed in collaboration with the Heart Rhythm Society. Circulation 2008;117(8):1101-20.

- European Heart Rhythm Association; European Association for Cardio-Thoracic Surgery. Guidelines for the management of atrial fibrillation: the Task Force for the Management of Atrial Fibrillation of the European Society of Cardiology (ESC). Eur Heart J 2010;31(19):2369-429.

- Scottish Intercollegiate Guidelines Network. Cardiac Arrhythmias in Coronary Heart Disease. http://www.sign. ac.uk/guidelines/fulltext/93-97/index.html

- Wann LS, Curtis AB, January CT, Ellenbogen KA, Lowe JE, Estes NA $3^{\text {rd }}$, et al; ACCF/AHA Task Force Members. 2011 ACCF/AHA/HRS focused update on the management of patients with atrial fibrillation (updating the 2006 guide(ine): a report of the American College of Cardiology Foundation/American Heart Association Task Force on Practice Guidelines. Circulation 2011;123(1):104-23.

- Zipes DP, Camm AJ, Borggrefe M, Buxton AE, Chaitman B, Fromer M, et al; American College of Cardiology/American Heart Association Task Force; European Society of Cardiology Committee for Practice Guidelines; European Heart Rhythm Association and the Heart Rhythm Society. ACC/AHA/ESC 2006 guidelines for management of patients with ventricular arrhythmias and the prevention of sudden cardiac death-executive summary: A report of the American College of Cardiology/American Heart Association Task Force and the European Society of Cardiology Committee for Practice Guidelines (Writing Committee to Develop Guidelines for Management of Patients with Ventricular Arrhythmias and the Prevention of Sudden Cardiac Death) Developed in collaboration with the European Heart Rhythm Association and the Heart Rhythm Society. Eur Heart J 2006;27(17): 2099-140.

\section{Patients with heart failure}

- Authors/Task Force Members, Dickstein K, Vardas PE, Auricchio A, Daubert JC, Linde C, McMurray J, et al. 2010 Focused Update of ESC Guidelines on device therapy in heart failure: an update of the 2008 ESC Guidelines for the diagnosis and treatment of acute and chronic heart failure and the 2007 ESC guidelines for cardiac and resynchronization therapy. Developed with the special contribution of the Heart Failure Association and the European Heart Rhythm Association. Eur Heart J 2010;31(21):2677-87.

- Bonow RO, Bennett S, Casey DE Jr, Ganiats TG, Hlatky MA, Konstam MA, et al; American College of Cardiology; American Heart Association Task Force on Performance Measures; Heart Failure Society of America. ACC/AHA Clinical Performance Measures for Adults with Chronic Heart Failure: a report of the American College of Cardiology/American Heart Association Task Force on Performance Measures (Writing Committee to Develop Heart Failure Clinical Performance Measures): endorsed by the Heart Failure Society of America. Circulation 2005;112(12): 1853-87.
- Francis GS, Greenberg BH, Hsu DT, Jaski BE, Jessup M, LeWinter MM, et al. ACCF/AHA/ACP/HFSA/ISHLT 2010 clinical competence statement on management of patients with advanced heart failure and cardiac transplant: a report of the ACCF/AHA/ACP Task Force on Clinical Competence and Training. Circulation 2010;122(6):644-72.

- Jessup M, Abraham WT, Casey DE, Feldman AM, Francis GS, Ganiats TG, et al. 2009 focused update: ACCF/AHA Guidelines for the Diagnosis and Management of Heart Failure in Adults: a report of the American College of Cardiology Foundation/American Heart Association Task Force on Practice Guidelines: developed in collaboration with the International Society for Heart and Lung Transplantation. Circulation 2009;119(14):1977-2016.

- NICE Chronic Heart Failure. National clinical guideline for diagnosis and management in primary and secondary care. www.rcplondon.ac.uk

- Task Force for Diagnosis and Treatment of Acute and Chronic Heart Failure 2008 of European Society of Cardiology; ESC Committee for Practice Guidelines. ESC Guidelines for the diagnosis and treatment of acute and chronic heart failure 2008: the Task Force for the Diagnosis and Treatment of Acute and Chronic Heart Failure 2008 of the European Society of Cardiology. Developed in collaboration with the Heart Failure Association of the ESC (HFA) and endorsed by the European Society of Intensive Care Medicine (ESICM). Eur Heart J 2008;29(19):2388-442.

- Vardas PE, Auricchio A, Blanc JJ, Daubert JC, Drexler H, Ector $\mathrm{H}$, et al; European Society of Cardiology; European Heart Rhythm Association. Guidelines for cardiac pacing and cardiac resynchronization therapy: The Task Force for Cardiac Pacing and Cardiac Resynchronization Therapy of the European Society of Cardiology. Developed in collaboration with the European Heart Rhythm Association. Eur Heart J 2007;28(18):2256-95.

- Weintraub NL, Collins SP, Pang PS, Levy PD, Anderson AS, Arslanian-Engoren $C$, et al; American Heart Association Council on Clinical Cardiology and Council on Cardiopulmonary, Critical Care, Perioperative and Resuscitation. Acute heart failure syndromes: emergency department presentation, treatment, and disposition: current approaches and future aims: a scientific statement from the American Heart Association. Circulation 2010;122(19): 1975-96.

\section{Patients with stroke}

- Adams HP Jr, del Zoppo G, Alberts MJ, Bhatt DL, Brass L, Furlan A, et al; American Heart Association; American Stroke Association Stroke Council; Clinical Cardiology Council; Cardiovascular Radiology and Intervention Council; Atherosclerotic Peripheral Vascular Disease and Quality of Care Outcomes in Research Interdisciplinary Working Groups. Guidelines for the early management of adults with ischemic stroke: a guideline from the American Heart Association/American Stroke Association Stroke Council, Clinical Cardiology Council, Cardiovascular Radiology and Intervention Council, and the Atherosclerotic Peripheral Vascular Disease and Quality of Care Outcomes in Research Interdisciplinary Working Groups: the American Academy 
of Neurology affirms the value of this guideline as an educational tool for neurologists. Stroke 2007;38(5): 1655-711.

- Broderick J, Connolly S, Feldmann E, Hanley D, Kase C, Krieger D, et al; American Heart Association; American Stroke Association Stroke Council; High Blood Pressure Research Council; Quality of Care and Outcomes in Research Interdisciplinary Working Group. Guidelines for the management of spontaneous intracerebral hemorrhage in adults: 2007 update: a guideline from the American Heart Association/American Stroke Association Stroke Council, High Blood Pressure Research Council, and the Quality of Care and Outcomes in Research Interdisciplinary Working Group. Stroke 2007;38(6):2001-23.

- Furie KL, Kasner SE, Adams RJ, Albers GW, Bush RL, Fagan SC, et al; American Heart Association Stroke Council, Council on Cardiovascular Nursing, Council on Clinical Cardiology, and Interdisciplinary Council on Quality of Care and Outcomes Research. Guidelines for the prevention of stroke in patients with stroke or transient ischemic attack: a guideline for healthcare professionals from the american heart association/american stroke association. Stroke 2011;42(1):227-76.

- Goldstein LB, Bushnell CD, Adams RJ, Appel LJ, Braun LT, Chaturvedi S, et al; American Heart Association Stroke Council; Council on Cardiovascular Nursing; Council on Epidemiology and Prevention; Council for High Blood Pressure Research; Council on Peripheral Vascular Disease, and Interdisciplinary Council on Quality of Care and Outcomes Research. Guidelines for the primary prevention of stroke: a guideline for healthcare professionals from the American Heart Association/American Stroke Association. Stroke 2011;42(2):517-84.

- Ingeman A, Andersen G, Hundborg HH, Svendsen ML, Johnsen SP. Processes of care and medical complications in patients with stroke. Stroke 2011;42(1):167-72.

- Leifer D, Bravata DM, Connors JJ, Hinchey JA, Jauch EC, Johnston SC, et al; on behalf of the American Heart Association Special Writing Group of the Stroke Council; Atherosclerotic Peripheral Vascular Disease Working Group; Council on Cardiovascular Surgery and Anesthesia; Council on Cardiovascular Nursing. Metrics for Measuring Quality of Care in Comprehensive Stroke Centers: Detailed Follow-Up to Brain Attack Coalition Comprehensive Stroke Center Recommendations. http://stroke.ahajournals. org/cgi/content/abstract/STR.0b013e318208eb99v1]

- Scottish Intercollegiate Guidelines Network. Management of Patients with Stroke: Identification and management of dysphagia. http://www.sign.ac.uk/guidelines/fulltext/ 119/index.html

- Smith EE, Shobha N, Dai D, Olson DM, Reeves MJ, Saver $\mathrm{JL}$, et al. Risk score for in-hospital ischemic stroke mortality derived and validated within the Get With the Guidelines-Stroke Program. Circulation 2010;122(15): 1496-504.

- Stroke Prevention and Educational Awareness Diffusion. Ictus cerebrale: linee guida italiane di prevenzione e trattamento. http://www.spread.it/node/60

- Wolfe CD, Redfern J, Rudd AG, Grieve AP, Heuschmann PU, McKevitt C. Cluster randomized controlled trial of a patient and general practitioner intervention to improve the management of multiple risk factors after stroke: stop stroke. Stroke 2010;41(11):2470-6.

\section{Patients with transient ischemic attack - TIA}

- Albers GW, Caplan LR, Easton JD, Fayad PB, Mohr JP, Saver $\mathrm{JL}$, et al; TIA Working Group. Transient ischemic attackProposal for a new definition. N Engl J Med 2002;347(21): 1713-6.

- Antithrombotic Trialists' Collaboration. Collaborative meta-analysis of randomised trials of antiplatelet therapy for prevention of death, myocardial infarction, and stroke in high risk patients. BMJ 2002;324(7329): 71-86.

- Caplan LR. A 70-year-old man with a transient ischemic attack: review of internal carotid artery stenosis. JAMA 2008;300(1):81-90.

- Scottish Intercollegiate Guidelines Network. Management of Patients with Stroke or TIA: Assessment, investigation, immediate management and secondary prevention. http://www.sign.ac.uk/guidelines/fulltext/108/index. html

\section{Patients with chronic obstructive pulmonary disease (COPD)}

- Celli BR, MacNee W; ATS/ERS Task Force. Standards for the diagnosis and treatment of patients with COPD: a summary of the ATS/ERS position paper. Eur Respir J 2004;23(6):93246.

- Global Initiative for Asthma. Global Strategy for Asthma Management and Prevention. Updated 2009. www. ginasthma.com

- Global Initiative for Chronic Obstructive Lung Disease. Global Strategy for the Diagnosis, Management and Prevention of Chronic Obstructive Pulmonary Disease. Updated 2009. http://www.goldcopd.com

- Institute for Clinical Systems Improvement. Health Care Guidelines. Diagnosis and Treatment of Respiratory Illness in Children and Adults. http://www.icsi.org/news/ new_and_recently_revised_scientific_documents_1455. html

- Institute for Clinical Systems Improvement. Health Care Guidelines. Diagnosis and Management of Chronic Obstructive Pulmonary Disease (COPD). http://www.icsi.org/ templates/documents.aspx?catID $=52$

- Institute for Clinical Systems Improvement. Health Care Guidelines. Diagnosis and Management of Asthma. http:// www.icsi.org/templates/documents. aspx?catID =52

- Reddel HK, Taylor DR, Bateman ED, Boulet LP, Boushey HA, Busse WW, et al; American Thoracic Society/European Respiratory Society Task Force on Asthma Control and Exacerbations. An official American Thoracic Society/ European Respiratory Society statement: asthma control and exacerbations: standardizing endpoints for clinical asthma trials and clinical practice. Am J Respir Crit Care Med 2009;180(1):59-99. 


\section{Patients with community acquired pneumonia}

- AAVV. Le infezioni nel paziente anziano. Linee guida FADOI. It J Med 2007;1(1 Suppl 2).

- American Thoracic Society; Infectious Diseases Society of America. Guidelines for the management of adults with hospital-acquired, ventilator-associated, and healthcareassociated pneumonia. Am J Respir Crit Care Med 2005;171(4):388-416.

- Blasi F, lori I, Bulfoni A, Corrao S, Costantino S, Legnani D. Can CAP guideline adherence improve patient outcome in internal medicine departments? Eur Respir J 2008;32(4): 902-10.

- Gussoni G, lori I, Blasi F, Bulfoni A, Costantino S, Giusti M, et al. Le polmoniti nei pazienti provenienti da residenze sanitarie assistenziali: è necessaria una strategia terapeutica dedicata? It J Med 2009;3(3):212-9.

- Iori I, Gussoni G, Blasi F, Bulfoni A, Costantino S, Legnani D. Linee guida e gestione ospedaliera delle polmoniti acquisite in comunità: l'esperienza italiana dello studio FASTCAP. It J Med 2008;2(2):5-18.

- Lazzaro C, lori I, Gussoni G. Studio FASTCAP sulla gestione ospedaliera delle polmoniti acquisite in comunità: valutazione farmacoeconomica della fase prospettica. It J Med 2008;2(2):55-66.

- Mandell LA, Wunderink RG, Anzueto A, Bartlett JG, Campbell GD, Dean NC, et al; Infectious Diseases Society of America; American Thoracic Society. Infectious Diseases Society of America/American Thoracic Society consensus guidelines on the management of community-acquired pneumonia in adults. Clin Infect Dis 2007;44 Suppl 2:S27-72.

- Renaud B, Coma E, Hayon J, Gurgui M, Longo C, Blancher $M$, et al; Pneumocom Study Investigators. Investigation of the ability of the Pneumonia Severity Index to accurately predict clinically relevant outcomes: a European study. Clin Microbiol Infect 2007;13(9):923-31.

- Renaud B, Coma E, Labarere J, Hayon J, Roy PM, Boureaux H, et al; Pneumocom Study Investigators. Routine use of the Pneumonia Severity Index for guiding the site-oftreatment decision of patients with pneumonia in the emergency department: a multicenter, prospective, observational, controlled cohort study. Clin Infect Dis 2007;44(1): 41-9.

- Torres A, Ewig S, Lode H, Carlet J; European HAP working group. Defining, treating and preventing hospital acquired pneumonia: European perspective. Intensive Care Med 2009;35(1):9-29.

- Woodhead M, Blasi F, Ewig S, Huchon G, leven M, Ortqvist A, et al; European Respiratory Society; European Society of Clinical Microbiology and Infectious Diseases. Guidelines for the management of adult lower respiratory tract infections. Eur Respir J 2005;26(6):1138-80.

- Yealy DM, Auble TE, Stone RA, Lave JR, Meehan TP, Graff $L G$, et al. Effect of increasing the intensity of implementing pneumonia guidelines: a randomized, controlled trial. Ann Intern Med 2005;143(12):881-94.

\section{Patients with nosocomial pneumonia}

- AAVV. Le infezioni nel paziente anziano. Linee guida FADOI. It J Med 2007;1(1 Suppl 2).
- American Thoracic Society; Infectious Diseases Society of America. Guidelines for the management of adults with hospital-acquired, ventilator-associated, and healthcareassociated pneumonia. Am J Respir Crit Care Med 2005;171(4):388-416.

- Carratalà J, Mykietiuk A, Fernández-Sabé N, Suárez C, Dorca J, Verdaguer R, et al. Health care-associated pneumonia requiring hospital admission: epidemiology, antibiotic therapy, and clinical outcomes. Arch Intern Med 2007;167(13):1393-9.

\section{Patients with anaemia}

- Guralnik JM, Eisenstaedt RS, Ferrucci L, Klein HG, Woodman RC. Prevalence of anemia in persons 65 years and older in the United States: evidence for a high rate of unexplained anemia. Blood 2004;104(8):2263-8.

- KDOQI. KDOQI Clinical Practice Guideline and Clinical Practice Recommendations for anemia in chronic kidney disease: 2007 update of hemoglobin target. Am J Kidney Dis 2007;50(3):471-530.

- KDOQI; National Kidney Foundation. KDOQI Clinical Practice Guidelines and Clinical Practice Recommendations for Anemia in Chronic Kidney Disease. Am J Kidney Dis 2006;47(5 Suppl 3):S11-145.

- Marsh JC, Ball SE, Cavenagh J, Darbyshire P, Dokal I, Gordon-Smith EC, et al; British Committee for Standards in Haematology. Guidelines for the diagnosis and management of aplastic anaemia. Br J Haematol 2009;147(1): 43-70.

- Mazzone A, Vezzoli M, Ottini E. Masked deficit of $B(12)$ and folic acid in thalassemia. Am J Hematol 2001;67(4): 274.

- Weiss G, Goodnough LT. Anemia of chronic disease. N Engl J Med 2005;352(10):1011-23.

- World Health Organization. Nutritional Anemias: Report of a WHO scientific group. Geneva: World Health Organization, 1968.

\section{Patients with mielodysplastic syndromes}

- British Committee for Standards in Haematology. Guidelines for the Diagnosis and Therapy of Adult Myelodysplastic Syndromes. 2003. http://www.bcshguidelines.com/ 4_HAEMATOLOGY_GUIDELINES

- Greenberg PL, Baer MR, Bennett JM, Bloomfield CD, De Castro CM, Deeg HJ, et al. Myelodysplastic syndromes clinical practice guidelines in oncology. J Natl Compr Canc Netw 2006;4(1):58-77.

- National Comprehensive Cancer Network. NCCN Updates Myelodysplastic Syndromes (MDS) Guidelines. http:// www.nccn.org/about/news/newsinfo. asp?NewsID=97

- Van Etten RA, Shannon KM. Focus on myeloproliferative diseases and myelodysplastic syndromes. Cancer Cell 2004;6(6):547-52.

\section{Patients with deep venous thromboembolism}

- Campanini M, Gussoni G, Silingardi M, Scannapieco G, Buniolo C, Valerio A, et al. Fattori di rischio per 
tromboembolismo venoso e profilassi nei pazienti ricoverati in Medicina Interna: analisi dello studio FADOI "GEMINI". It J Med 2010;4(4):24-31.

- Geerts WH, Bergqvist D, Pineo GF, Heit JA, Samama CM, Lassen MR, et al; American College of Chest Physicians. Prevention of venous thromboembolism: American College of Chest Physicians Evidence-Based Clinical Practice Guidelines (8 ${ }^{\text {th }}$ Edition). Chest 2008;133(6 Suppl):381-453S.

- Gussoni G, Campanini M, Silingardi M, Scannapieco G, Mazzone A, Magni G, et al; GEMINI Study Group. In-hospital symptomatic venous thromboembolism and antithrombotic prophylaxis in Internal Medicine. Findings from a multicenter, prospective study. Thromb Haemost 2009;101(5):893901.

- Institute for Clinical Systems Improvement. Health Care Guidelines. Venous Thromboembolism Diagnosis and Treatment. http://www.icsi.org/templates/documents.aspx? cat ID $=12$ \&page $I D=8$

- NICE. Venous Thromboembolism: Reducing the Risk of VTE (DVT and PE) in Patients Admitted to Hospital. http:// guidance.nice.org.uk/CG92

- Scannapieco G, Ageno W, Airoldi A, Bonizzoni E, Campanini $M$, Gussoni G, et al; TERSICORE Study Group. Incidence and predictors of venous thromboembolism in post-acute care patients. A prospective cohort study. Thromb Haemost 2010;104(4):734-40.

- Scottish Intercollegiate Guidelines Network. Prevention and Management of Venous Thromboembolism. http:// www.sign.ac.uk/guidelines/fulltext/122/index.html

- Torbicki A, Perrier A, Konstantinides S, Agnelli G, Galiè N, Pruszczyk P, et al; ESC Committee for Practice Guidelines (CPG). Guidelines on the diagnosis and management of acute pulmonary embolism: the Task Force for the Diagnosis and Management of Acute Pulmonary Embolism of the European Society of Cardiology (ESC). Eur Heart J 2008;29(18):2276-315.

\section{Patients with diabetes mellitus}

- American Diabetes Association. Standards of medical care in diabetes-2011. Diabetes Care 2011;34 Suppl 1:S11-61.

- Rydén L, Standl E, Bartnik M, Van den Berghe G, Betteridge $\mathrm{J}$, de Boer MJ, et al; Task Force on Diabetes and Cardiovascular Diseases of the European Society of Cardiology (ESC); European Association for the Study of Diabetes (EASD). Guidelines on diabetes, pre-diabetes, and cardiovascular diseases: executive summary. The Task Force on Diabetes and Cardiovascular Diseases of the European Society of Cardiology (ESC) and of the European Association for the Study of Diabetes (EASD). Eur Heart J 2007;28(1):88-136.

- Scottish Intercollegiate Guidelines Network. Management of Diabetes. http://www.sign.ac.uk/guidelines/fulltext/ 116/index.html

- Società Italiana di Diabetologia. Standard italiani per la cura del diabete mellito 2009-2010. http://www. progettodiabete.org/pdf/2010_linee_guida_amd.pdf

\section{Patients with peripheral arteriopathy of the lower limbs}

- Hirsch AT, Haskal ZJ, Hertzer NR, Bakal CW, Creager MA, Halperin JL, et al; American Association for Vascular
Surgery; Society for Vascular Surgery; Society for Cardiovascular Angiography and Interventions; Society for Vascular Medicine and Biology; Society of Interventional Radiology; ACC/AHA Task Force on Practice Guidelines Writing Committee to Develop Guidelines for the Management of Patients With Peripheral Arterial Disease; American Association of Cardiovascular and Pulmonary Rehabilitation; National Heart, Lung, and Blood Institute; Society for Vascular Nursing; TransAtlantic InterSociety Consensus; Vascular Disease Foundation. ACC/ AHA 2005 Practice Guidelines for the management of patients with peripheral arterial disease (lower extremity, renal, mesenteric, and abdominal aortic): a collaborative report from the American Association for Vascular Surgery/Society for Vascular Surgery, Society for Cardiovascular Angiography and Interventions, Society for Vascular Medicine and Biology, Society of Interventional Radiology, and the ACC/AHA Task Force on Practice Guidelines (Writing Committee to Develop Guidelines for the Management of Patients With Peripheral Arterial Disease): endorsed by the American Association of Cardiovascular and Pulmonary Rehabilitation; National Heart, Lung, and Blood Institute; Society for Vascular Nursing; TransAtlantic Inter-Society Consensus; and Vascular Disease Foundation. Circulation 2006;113(11):e463-654.

- Olin JW, Allie DE, Belkin M, Bonow RO, Casey DE Jr, Creager MA, et al. ACCF/AHA/ACR/SCAI/SIR/SVM/SVN/ SVS 2010 performance measures for adults with peripheral artery disease: a report of the American College of Cardiology Foundation/American Heart Association Task Force on performance measures, the American College of Radiology, the Society for Cardiac Angiography and Interventions, the Society for Interventional Radiology, the Society for Vascular Medicine, the Society for Vascular Nursing, and the Society for Vascular Surgery (Writing Committee to Develop Clinical Performance Measures for Peripheral Artery Disease). Circulation 2010;122(24): 2583-618.

\section{Patients with acute and chronic renal insufficiency}

- Boero R, Degli Esposti E, Galli G, Losito A, Mambelli E, Stella I. Linee guida per la nefropatia ischemica arteriosclerotica. www.sin-italy.org/pdf/linee_guida/LG_ nefropatia_ischemica.pdf

- Cianciaruso B; Italian Society of Nephrology. Conservative therapy guidelines for chronic renal failure. G Ital Nefrol 2003;20 Suppl 24:S48-60.

- Fuiano G, Di Filippo S, Memoli B, Cioffi M, Caglioti A, Mazza G; Italian Society of Nephrology. Guidelines for dialysis. Replacement therapy for acute renal failure in critically ill patients. G Ital Nefrol 2004;21 Suppl 28:S1-10.

- Levey AS, Coresh J, Balk E, Kausz AT, Levin A, Steffes MW, et al; National Kidney Foundation. National Kidney Foundation practice guidelines for chronic kidney disease: evaluation, classification, and stratification. Ann Intern Med 2003;139(2):137-47.

- National Service Framework for Renal Services. Part Two: Chronic kidney disease acute renal failure and end 
of life care. http://www.dh.gov.uk/en/Publicationsandstatistics/Publications/PublicationsPolicyAndGuidance/ Browsable/DH_4102941

- NICE Guideline. Early Identification and Management of Chronic Kidney Disease in Adults in Primary and Secondary care. http: //www.nice.org.uk/CG73

- NICE. Early Identification and Management of Chronic Kidney Disease in Adults in Primary and Secondary Care. http: / /guidance.nice.org.uk/CG73

- Scottish Intercollegiate Guidelines Network. Diagnosis and Management of Chronic Kidney Disease. http: / /www.sign. ac.uk/guidelines/fulltext/103/index.html

\section{Patients with hydro-electrolytic imbalances}

- American Medical Directors Association (AMDA). Dehydration and fluid maintenance in the long-term care setting. Columbia (MD): American Medical Directors Association (AMDA); 2009. http://www.guideline.gov/content. aspx?id $=15590$

- Brandstrup B, Tønnesen H, Beier-Holgersen R, Hjortsø E, Ørding $\mathrm{H}$, Lindorff-Larsen $\mathrm{K}$, et al; Danish Study Group on Perioperative Fluid Therapy. Effects of intravenous fluid restriction on postoperative complications: comparison of two perioperative fluid regimens: a randomized assessor-blinded multicenter trial. Ann Surg 2003;238(5): 641-8.

- Khosla S. Ipercalcemia e ipocalcemia. In: Fauci AS, Braunwald E, Kasper DL, Hauser SL, Longo DL, Jameson JL, et al (eds). Harrison - Principi di medicina interna. $17^{\mathrm{a}}$ Ed. Milano: McGraw-Hill, 2009, p. 285.

- Møller AM, Pedersen T, Svendsen PE, Engquist A. Perioperative risk factors in elective pneumonectomy: the impact of excess fluid balance. Eur J Anaesthesiol 2002;19(1): 57-62.

- Scottish Intercollegiate Guidelines Network. Postoperative Management in Adults. www.sign.ac.uk/guidelines/ fulltext/77/index.html

- Sgambato F, Prozzo S, Caporaso C, Milano L, Sgambato E, Piscitelli GL. La fisiopatologia clinica delle ipersodiemie. It J Med 2007;1(1 Suppl 2):6-18.

- Sgambato F, Prozzo S. Le iponatriemie: problemi diagnostici e terapeutici, semplici e complessi. G It Medicina Interna 2003;2(Suppl 2):8-37.

- Singer GG, Brenner BM. Alterazioni dei liquidi e degli elettroliti. In: Fauci AS, Braunwald E, Kasper DL, Hauser SL, Longo DL, Jameson JL, et al (eds). Harrison - Principi di medicina interna. $17^{\mathrm{a}}$ Ed. Milano: McGraw-Hill, 2009, p. 274.

\section{Patients with alterations of the acid/base equilibrium}

- DuBose TD. Acidosi e alcalosi. In: Fauci AS, Braunwald E, Kasper DL, Hauser SL, Longo DL, Jameson JL, et al (eds). Harrison - Principi di medicina interna. $17^{\mathrm{a}}$ Ed. Milano: McGraw-Hill, 2009, p. 287.

- Sgambato F. Polmone e interrelazioni tra sistemi. It J Med 2009;3(3 Speciale 2):2-5.

\section{Patients hospitalised with malnutrition}

- ASPEN Board of Directors and the Clinical Guidelines Task Force. Guidelines for the use of parenteral and enteral nutrition in adult and pediatric patients. JPEN J Parenter Enteral Nutr 2002;26(1 Suppl):1-138SA.

- Botella-Carretero JI, Carrero C, Arrieta F, Balsa J, Zamarrón I, Vázquez C. Role of peripherally inserted central catheters (PICC) in home and in-hospital parenteral nutrition. Nutritional Therapy \& Metabolism 2009;27(2): 55-61.

- Bozzetti F, Arends J, Lundholm K, Micklewright A, Zurcher G, Muscaritoli M; ESPEN. ESPEN Guidelines on Parenteral Nutrition: non-surgical oncology. Clin Nutr 2009;28(4): 445-54.

- Bozzetti F, Forbes A. The ESPEN clinical practice Guidelines on Parenteral Nutrition: present status and perspectives for future research. Clin Nutr 2009;28(4):359-64.

- ESPEN Guidelines on Enteral Nutrition. Clin Nutr 2006; 25:180-360.

- Kondrup J, Allison SP, Elia M, Vellas B, Plauth M; Educational and Clinical Practice Committee, European Society of Parenteral and Enteral Nutrition (ESPEN). ESPEN guidelines for nutrition screening 2002. Clin Nutr 2003;22(4):415-21.

- Löser C, Aschl G, Hébuterne X, Mathus-Vliegen EM, Muscaritoli M, Niv $Y$, et al. ESPEN guidelines on artificial enteral nutrition-percutaneous endoscopic gastrostomy (PEG). Clin Nutr 2005;24(5):848-61.

- NICE. Nutrition Support in Sdults. http://guidance. nice.org.uk/CG32

- Nutrition support in adults: oral nutrition support, enteral tube feeding and parenteral nutrition. February 2006. London: Royal College of Surgeons of England, 2006; 1-247.

- SINPE. Linee guida SINPE per la nutrizione artificiale ospedaliera 2002. http: //www.sinpe.it/LineeGuida.aspx

- Westaby D, Young A, O'Toole P, Smith G, Sanders DS. The provision of a percutaneously placed enteral tube feeding service. Gut 2010;59(12):1592-605.

\section{Patients with nodular pathology of the thyroid}

- Cooper DS, Doherty GM, Haugen BR, Kloos RT, Lee SL, Mandel SJ, et al; American Thyroid Association Guidelines Taskforce. Management guidelines for patients with thyroid nodules and differentiated thyroid cancer. Thyroid 2006;16(2):109-42.

- Gharib H, Papini E, Paschke R, Duick DS, Valcavi R, Hegedüs $\mathrm{L}$, et al; AACE/AME/ETA Task Force on Thyroid Nodules. American Association of Clinical Endocrinologists, Associazione Medici Endocrinologi, and EuropeanThyroid Association medical guidelines for clinical practice for the diagnosis and management of thyroid nodules. Endocr Pract 2010;16 Suppl 1:1-43.

\section{Patients with thyroid dysfunction}

- Baskin HJ, Cobin RH, Duick DS, Gharib H, Guttler RB, Kaplan MM, et al; American Association of Clinical 
Endocrinologists. American Association of Clinical Endocrinologists medical guidelines for clinical practice for the evaluation and treatment of hyperthyroidism and hypothyroidism. Endocr Pract 2002;8(6):457-69.

\section{Patients with hepatic cirrhosis}

- AISF. Linee guida AISF per l'ipertensione portale. 2006. http: / / www.webaisf.org/index.php?option=com_docman\&task =search_result\&ltemid=73\&lang $=$ it

- Angeli P, Merkel C. Pathogenesis and management of hepatorenal syndrome in patients with cirrhosis. J Hepatol 2008;48 Suppl 1:S93-103.

- Bosch J, Berzigotti A, Garcia-Pagan JC, Abraldes JG. The management of portal hypertension: rational basis, available treatments and future options. J Hepatol 2008;48 Suppl 1:S68-92.

- Child CG, Turcotte JG. Surgery and portal hypertension. In: Child CG (ed). The Liver and Portal Hypertension. Philadelphia, PA: WB Saunders, 1964, pp. 1-85 (tables 1-4, p. 50).

- Ghany MG, Strader DB, Thomas DL, Seeff LB; American Association for the Study of Liver Diseases. Diagnosis, management, and treatment of hepatitis C: an update. Hepatology 2009;49(4):1335-74.

- Ginès P, Cárdenas A, Arroyo V, Rodés J. Management of cirrhosis and ascites. N Engl J Med 2004;350(16): 1646-54.

- Ginès P, Schrier RW. Renal failure in cirrhosis. N Engl J Med 2009;361(13):1279-90.

- Kim WR, Poterucha JJ, Wiesner RH, LaRusso NF, Lindor KD, Petz J, et al. The relative role of the Child-Pugh classification and the Mayo natural history model in the assessment of survival in patients with primary sclerosing cholangitis. Hepatology 1999;29(6):1643-8.

- Parikh S, Shah R, Kapoor P. Portal vein thrombosis. Am J Med 2010;123(2):111-9.

- Poupon R. Primary biliary cirrhosis: a 2010 update. J Hepatol 2010;52(5):745-58.

- Wallerstedt S, Olsson R, Simrén M, Broomé U, Wahlin S, Lööf $\mathrm{L}$, et al. Abdominal tenderness in ascites patients indicates spontaneous bacterial peritonitis. Eur J Intern Med 2007;18(1):44-7.

\section{Patients with gastrointestinal bleeding}

- Adler DG, Leighton JA, Davila RE, Hirota WK, Jacobson BC, Qureshi WA, et al; ASGE. ASGE guideline: The role of endoscopy in acute non-variceal upper-Gl hemorrhage. Gastrointest Endosc 2004;60(4):497-504.

- ASGE Standards of Practice Committee, Fisher L, Lee Krinsky M, Anderson MA, Appalaneni V, Banerjee S, Ben-Menachem T, et al. The role of endoscopy in the management of obscure GI bleeding. Gastrointest Endosc 2010;72(3):471-9.

- Barkun AN, Bardou M, Kuipers EJ, Sung J, Hunt RH, Martel $M$, et al; International Consensus Upper Gastrointestinal Bleeding Conference Group. International consensus recommendations on the management of patients with nonvariceal upper gastrointestinal bleeding. Ann Intern Med 2010;152(2):101-13.

- de Franchis R. Evolving consensus in portal hypertension. Report of the Baveno IV consensus workshop on methodology of diagnosis and therapy in portal hypertension. J Hepatol 2005;43(1):167-76.

- Dell'Era A, Rojas-Gonzalez DP, Primignani M, de Franchis R. Emorragie digestive alte da varici: update 2008-2009. G Ital End Dig 2010;33:185-9.

- Garcia-Tsao G, Bosch J. Management of varices and variceal hemorrhage in cirrhosis. N Engl J Med 2010;362(9): 823-32.

- Jalan R, Hayes PC. UK guidelines on the management of variceal haemorrhage in cirrhotic patients. British Society of Gastroenterology. Gut 2000;46 Suppl 3-4:III1-15.

- Levacher S, Letoumelin P, Pateron D, Blaise M, Lapandry C, Pourriat JL. Early administration of terlipressin plus glyceryl trinitrate to control active upper gastrointestinal bleeding in cirrhotic patients. Lancet 1995;346(8979): 865-8.

- Palmer K, Nairn M; Guideline Development Group. Management of acute gastrointestinal blood loss: summary of SIGN guidelines. BMJ 2008;337:a1832.

- Pohl J, Delvaux M, Ell C, Gay G, May A, Mulder CJ, et al; ESGE Clinical Guidelines Committee. European Society of Gastrointestinal Endoscopy (ESGE) Guidelines: flexible enteroscopy for diagnosis and treatment of small-bowel diseases. Endoscopy 2008;40(7):609-18.

- Rockall TA, Logan RF, Devlin HB, Northfield TC. Risk assessment after acute upper gastrointestinal haemorrhage. Gut 1996;38(3):316-21.

- Sidhu R, Sanders DS, Morris AJ, McAlindon ME. Guidelines on small bowel enteroscopy and capsule endoscopy in adults. Gut 2008;57(1):125-36.

- Sung JJ, Lau JY, Ching JY, Wu JC, Lee YT, Chiu PW, et al. Continuation of low-dose aspirin therapy in peptic ulcer bleeding: a randomized trial. Ann Intern Med 2010;152(1): 1-9.

\section{Patients with acute pancreatitis}

- American Gastroenterological Association (AGA) Institute on "Management of Acute Pancreatits" Clinical Practice and Economics Committee; AGA Institute Governing Board. AGA Institute medical position statement on acute pancreatitis. Gastroenterology 2007;132(5):2019-21.

- Banks PA, Freeman ML; Practice Parameters Committee of the American College of Gastroenterology. Practice guidelines in acute pancreatitis. Am J Gastroenterol 2006;101(10):2379-400.

- Forsmark CE, Baillie J; AGA Institute Clinical Practice and Economics Committee; AGA Institute Governing Board. AGA Institute technical review on acute pancreatitis. Gastroenterology 2007;132(5):2022-44.

- Harrison DA, D’Amico G, Singer M. The Pancreatitis Outcome Prediction (POP) Score: a new prognostic index for patients with severe acute pancreatitis. Crit Care Med 2007;35(7):1703-8.

- Takeda K, Takada T, Kawarada Y, Hirata K, Mayumi T, Yoshida M, et al; JPN. JPN guidelines for the management of acute pancreatitis: medical management of acute 
pancreatitis. J Hepatobiliary Pancreat Surg 2006;13(1): 42-7.

- Working Party of the British Society of Gastroenterology; Association of Surgeons of Great Britain and Ireland; Pancreatic Society of Great Britain and Ireland; Association of Upper GI Surgeons of Great Britain and Ireland. UK guidelines for the management of acute pancreatitis. Gut 2005;54 Suppl 3:iii1-9.

\section{Patients with chronic pancreatitis}

- Adler DG, Lichtenstein D, Baron TH, Davila R, Egan JV, Gan SL, et al. The role of endoscopy in patients with chronic pancreatitis. Gastrointest Endosc 2006;63(7): 933-7.

- Frulloni L, Falconi M, Gabbrielli A, Gaia E, Graziani R, Pezzilli R, et al; Italian Association for the Study of the Pancreas (AISP). Italian consensus guidelines for chronic pancreatitis. Dig Liver Dis 2010;42 Suppl 6:S381-406.

\section{Patients with fever of an unknown origin}

- AAVV. Le infezioni nel paziente anziano. Linee guida FADOI. It J Med 2007;1(1 Suppl 2).

- De Klein E, Knockaert DC, Van Der Meer J. Fever of unknown origin: a new definition and proposal for diagnostic work-up. Eur J Int Med 2000;11:1-3.

- Knockaert DC, Dujardin KS, Bobbaers HJ. Long-term follow-up of patients with undiagnosed fever of unknown origin. Arch Intern Med 1996;156(6):618-20.

- Mourad O, Palda V, Detsky AS. A comprehensive evidencebased approach to fever of unknown origin. Arch Intern Med 2003;163(5):545-51.

- Woolery WA, Franco FR. Fever of unknown origin: keys to determining the etiology in older patients. Geriatrics 2004;59(10):41-5.

\section{Patients with sepsis}

- Alberti C, Brun-Buisson C, Chevret S, Antonelli M, Goodman SV, Martin C, et al; European Sepsis Study Group. Systemic inflammatory response and progression to severe sepsis in critically ill infected patients. Am J Respir Crit Care Med 2005;171(5):461-8.

- Brun-Buisson C, Doyon F, Carlet J, Dellamonica P, Gouin F, Lepoutre A, et al. Incidence, risk factors, and outcome of severe sepsis and septic shock in adults. A multicenter prospective study in intensive care units. French ICU Group for Severe Sepsis. JAMA 1995;274(12):968-74.

- Dellinger RP, Carlet JM, Masur H, Gerlach H, Calandra T, Cohen J, et al. Surviving Sepsis Campaign guidelines for management of severe sepsis and septic shock. Intensive Care Med 2004;30(4):536-55.

- Dellinger RP, Levy MM, Carlet JM, Bion J, Parker MM, Jaeschke R, et al; International Surviving Sepsis Campaign Guidelines Committee; American Association of CriticalCare Nurses; American College of Chest Physicians; American College of Emergency Physicians; Canadian Critical Care Society; European Society of Clinical Microbiology and Infectious Diseases; European Society of Intensive Care Medicine; European Respiratory Society; International Sepsis Forum; Japanese Association for Acute Medicine; Japanese Society of Intensive Care Medicine; Society of Critical Care Medicine; Society of Hospital Medicine; Surgical Infection Society; World Federation of Societies of Intensive and Critical Care Medicine. Surviving Sepsis Campaign: international guidelines for management of severe sepsis and septic shock: 2008. Crit Care Med 2008;36(1):296-327.

- Green RS, Djogovic D, Gray S, Howes D, Brinddley PG, Stenstrom R, et al. Canadian Association of Emergency Physicians Sepsis Guidelines: The optimal management of severe sepsis in Canadian emergency departments. http: / / www.cjem-online.ca/sites/default/files / pg443(2).pdf

- Osborn TM, Nguyen HB, Rivers EP. Emergency medicine and the surviving sepsis campaign: an international approach to managing severe sepsis and septic shock. Ann Emerg Med 2005;46(3):228-31.

- Shapiro NI, Howell MD, Talmor D, Lahey D, Ngo L, Buras J, et al. Implementation and outcomes of the Multiple Urgent Sepsis Therapies (MUST) protocol. Crit Care Med 2006;34(4):1025-32.

- Dellinger RP, Levy MM, Carlet JM, Bion J, Parker MM, Jaeschke R, et al: Surviving Sepsis Campaign: International guidelines for management of severe sepsis and septic shock: 2008. http://www.survivingsepsis.org/About_the_ Campaign/Documents/Final\%2008\%20SSC\%20Guidelines. pdf

- Vincent JL, Moreno R, Takala J, Willatts S, De Mendonça A, Bruining $\mathrm{H}$, et al. The SOFA (Sepsis-related Organ Failure Assessment) score to describe organ dysfunction/failure. On behalf of the Working Group on Sepsis-Related Problems of the European Society of Intensive Care Medicine. Intensive Care Med 1996;22(7):707-10.

- Wang HE, Shapiro NI, Angus DC, Yealy DM. National estimates of severe sepsis in United States emergency departments. Crit Care Med 2007;35(8):1928-36.

\section{Patients with depression}

- Institute for Clinical Systems Improvement. Health Care Guideline. Major Depression in Adults in Primary Care. http://www.icsi.org/templates/documents.aspx?ca$\mathrm{tID}=12 \&$ pagelD $=2$

- NICE. Depression: The treatment and management of depression in adults. http://guidance.nice.org.uk/CG90

- O'Connell H, Chin AV, Cunningham C, Lawlor BA. Recent developments: suicide in older people. BMJ 2004; 329(7471):895-9.

\section{Patients with delirium}

- Britton A, Russell R. Multidisciplinary team interventions for delirium in patients with chronic cognitive impairment. Cochrane Database Syst Rev 2004;(2):CD000395.

- Mussi C, Salvioli G. Linee guida per la diagnosi e la terapia del delirium nell'anziano. G Gerontol 2000;48:434-40. 
- Naughton BJ, Saltzman S, Ramadan F, Chadha N, Priore R, Mylotte JM. A multifactorial intervention to reduce prevalence of delirium and shorten hospital length of stay. J Am Geriatr Soc 2005;53(1):18-23.

- NICE. Delirium: Diagnosis, prevention and management. http://guidance.nice.org.uk/CG103

\section{Patients with cognitive dysfunction, dementia}

- Bridges-Webb CB, Wolk MJ for the Royal Australian College of General Practitioners. Care of Patients with Dementia in General Practice. Guidelines. http://www.racgp.org.au/ Content/NavigationMenu/ClinicalResources/RACGPGuidelines/CareofPatientswithDementia/20060413dementiaguidelines.pdf

- Iverson DJ, Gronseth GS, Reger MA, Classen S, Dubinsky RM, Rizzo M; Quality Standards Subcomittee of the American Academy of Neurology. Practice parameter update: evaluation and management of driving risk in dementia: report of the Quality Standards Subcommittee of the American Academy of Neurology. Neurology 2010; 74(16):1316-24.

- NICE. Dementia: supporting people with dementia and their carers in health and social care. http://guidance. nice.org.uk/CG42

- Qaseem A, Snow V, Cross JT Jr, Forciea MA, Hopkins R Jr, Shekelle P, et al; American College of Physicians/American Academy of Family Physicians Panel on Dementia. Current pharmacologic treatment of dementia: a clinical practice guideline from the American College of Physicians and the American Academy of Family Physicians. Ann Intern Med 2008;148(5):370-8.

- Scottish Intercollegiate Guidelines Network. Management of Patients with Dementia. http://www.sign.ac.uk/ guidelines/fulltext/86/index.html

\section{Patients with pain}

- American Geriatrics Society Panel on Pharmacological Management of Persistent Pain in Older Persons. Pharmacological management of persistent pain in older persons. J Am Geriatr Soc 2009;57(8):1331-46.

- Canadian Guideline for Safe and Effective Use of Opioids for Chronic Non-Cancer Pain. http://nationalpaincentre. mcmaster.ca/opioid/

- Management of Opioid Therapy for Chronic Pain Working Group. VA/DoD clinical practice guideline for management of opioid therapy for chronic pain. Washington (DC): Department of Veterans Affairs, http://www.guidelines.gov/content. aspx?id=16313

- NICE Clinical Guideline 88. Low Back Pain: Quick reference guide. http: / /www.nice.org.uk/CG88quickrefguide

- NICE Clinical Guideline 96. Neuropathic Pain: The pharmacological management of neuropathic pain in adults in nonspecialist settings. http://www.nice.org.uk/CG96

- Scottish Intercollegiate Guidelines Network. Control of Pain in Adults with Cancer. http://www.sign.ac.uk/ guidelines/fulltext/106/index.html

\section{Patients with osteoporosis}

- Grossman J, MacLean CH. Quality indicators for the care of osteoporosis in vulnerable elders. J Am Geriatr Soc 2007;55 Suppl 2:S392-402.

- Linee guida per la diagnosi, prevenzione e terapia della osteoporosi. Reumatismo 2009;61:1-26.

- NICE. Osteoporosis - Primary prevention. Alendronate, etidronate, risedronate, raloxifene and strontium ranelate for the primary prevention of osteoporotic fragility fractures in postmenopausal women. http://guidance.nice. org.uk/TA160

\section{Patients with arterial hypertension}

- Mancia G, De Backer G, Dominiczak A, Cifkova R, Fagard R, Germano G, et al. 2007 Guidelines for the management of arterial hypertension: The Task Force for the Management of Arterial Hypertension of the European Society of Hypertension (ESH) and of the European Society of Cardiology (ESC). Eur Heart J 2007;28(12):1462-536.

- Torre JJ, Bloomgarden ZT, Dickey RA, Hogan MJ, Janick JJ, Jyothinagaram SG, et al; AACE Hypertension Task Force. American Association of Clinical Endocrinologists Medical Guidelines for Clinical Practice for the diagnosis and treatment of hypertension. Endocr Pract 2006;12(2):193-222.

- Scottish Intercollegiate Guidelines Network. Hypertension in Older People. http://www.sign.ac.uk/guidelines/ fulltext/49/index.html

\section{Technical-professional aspects and abilities (general and specific)}

\section{Electrocardiography}

- Hancock EW, Deal BJ, Mirvis DM, Okin P, Kligfield P, Gettes LS, et al; American Heart Association Electrocardiography and Arrhythmias Committee, Council on Clinical Cardiology; American College of Cardiology Foundation; Heart Rhythm Society. AHA/ACCF/HRS recommendations for the standardization and interpretation of the electrocardiogram: part V: electrocardiogram changes associated with cardiac chamber hypertrophy: a scientific statement from the American Heart Association Electrocardiography and Arrhythmias Committee, Council on Clinical Cardiology; the American College of Cardiology Foundation; and the Heart Rhythm Society: endorsed by the International Society for Computerized Electrocardiology. Circulation 2009;119(10):e251-61.

- Kligfield P, Gettes LS, Bailey JJ, Childers R, Deal BJ, Hancock EW, et al; American Heart Association Electrocardiography and Arrhythmias Committee, Council on Clinical Cardiology; American College of Cardiology Foundation; Heart Rhythm Society. Recommendations for the standardization and interpretation of the electrocardiogram: part I: The electrocardiogram and its technology: a scientific statement from the American Heart Association Electrocardiography and Arrhythmias Committee, Council on Clinical Cardiology; the American College 
of Cardiology Foundation; and the Heart Rhythm Society: endorsed by the International Society for Computerized Electrocardiology. Circulation 2007;115(10):1306-24.

- Mason JW, Hancock EW, Gettes LS; American Heart Association Electrocardiography and Arrhythmias Committee, Council on Clinical Cardiology; American College of Cardiology Foundation; Heart Rhythm Society. Recommendations for the standardization and interpretation of the electrocardiogram: part II: Electrocardiography diagnostic statement list: a scientific statement from the American Heart Association Electrocardiography and Arrhythmias Committee, Council on Clinical Cardiology; the American College of Cardiology Foundation; and the Heart Rhythm Society: endorsed by the International Society for Computerized Electrocardiology. Circulation 2007;115(10):132532.

- Rautaharju PM, Surawicz B, Gettes LS, Bailey JJ, Childers $\mathrm{R}$, Deal BJ, et al; American Heart Association Electrocardiography and Arrhythmias Committee, Council on Clinical Cardiology; American College of Cardiology Foundation; Heart Rhythm Society. AHA/ACCF/HRS recommendations for the standardization and interpretation of the electrocardiogram: part IV: the ST segment, T and U waves, and the QT interval: a scientific statement from the American Heart Association Electrocardiography and Arrhythmias Committee, Council on Clinical Cardiology; the American College of Cardiology Foundation; and the Heart Rhythm Society: endorsed by the International Society for Computerized Electrocardiology. Circulation 2009;119(10):e24150.

- Surawicz B, Childers R, Deal BJ, Gettes LS, Bailey JJ, Gorgels A, et al; American Heart Association Electrocardiography and Arrhythmias Committee, Council on Clinical Cardiology; American College of Cardiology Foundation; Heart Rhythm Society. AHA/ACCF/HRS recommendations for the standardization and interpretation of the electrocardiogram: part III: intraventricular conduction disturbances: a scientific statement from the American Heart Association Electrocardiography and Arrhythmias Committee, Council on Clinical Cardiology; the American College of Cardiology Foundation; and the Heart Rhythm Society: endorsed by the International Society for Computerized Electrocardiology. Circulation 2009;119(10):e235-40.

- Wagner GS, Macfarlane P, Wellens H, Josephson M, Gorgels A, Mirvis DM, et al; American Heart Association Electrocardiography and Arrhythmias Committee, Council on Clinical Cardiology; American College of Cardiology Foundation; Heart Rhythm Society. AHA/ACCF/HRS recommendations for the standardization and interpretation of the electrocardiogram: part VI: acute ischemia/infarction: a scientific statement from the American Heart Association Electrocardiography and Arrhythmias Committee, Council on Clinical Cardiology; the American College of Cardiology Foundation; and the Heart Rhythm Society: endorsed by the International Society for Computerized Electrocardiology. Circulation 2009;119(10):e262-70.

\section{Ecography}

- ACEP (American College of Emergency Physician Emergency). Ultrasound Guidelines. 2001. http://www.acep. org/content. aspx?id=30276
- Arienti V. Ecografia clinica del tratto gastroenterico. Modena: Athena Audiovisuals, 2006.

- Erlicher A, Corrado G. Patent foramen ovale, stroke, and echocardiography: diagnostic methodology and appropriateness of indications. G Ital Cardiol (Rome) 2006;7(8): 523-34.

- Kendall JL, Shimp RJ. Performance and interpretation of focused right upper quadrant ultrasound by emergency physicians. J Emerg Med 2001;21(1):7-13.

- Sistema Nazionale per le Linee Guida. Impiego della diagnostica per immagini delle lesioni focali epatiche. documento 18. Settembre 2008. http://www.snlg-iss.it/cms/ files/LG_Diagno_01-64_2008.pdf

- SIUMB-SIRMN. Documento congiunto sulla gestione dell'ecografia. G It Ecografia 1998;4:237-8.

- Società Italiana di Ecografia Cardiovascolare. http:// www.siec.it/index.php

- Società Italiana di Ultrasonologia in Medicina e Biologia. Documento SIUMB per le linee guida in ecografia. G It Ecografia 2005.

- Società Italiana di Ultrasonologia in Medicina e Biologia. Standard per una corretta esecuzione dell'esame ecografico. J Ultrasound 2009 Nov;Speciale.

\section{Procedures}

- Kuiper JJ, van Buuren HR, de Man RA. Ascites in cirrhosis: a review of management and complications. Neth J Med 2007;65(8):283-8.

- Mercadante S, Intravaia G, Ferrera P, Villari P, David F. Peritoneal catheter for continuous drainage of ascites in advanced cancer patients. Support Care Cancer 2008; 16(8):975-8.

- Nazeer SR, Dewbre H, Miller AH. Ultrasound-assisted paracentesis performed by emergency physicians vs the traditional technique: a prospective, randomized study. Am J Emerg Med 2005;23(3):363-7.

- Reichman E, Simon RR. Emergency Medicine Procedures. New York: McGraw-Hill Professional, 2003.

- The Merck Manual of Medical Information. Second Home Edition. Common medical tests. http://www.merckmanuals.com/home/print/appendixes/ap2/ap2a.html

- Thomsen TW, DeLaPena J, Setnik GS. Videos in clinical medicine. Thoracentesis. N Engl J Med 2006;355(15):e16.

- Thomsen TW, Shaffer RW, White B, Setnik GS. Videos in clinical medicine. Paracentesis. N Engl J Med 2006; 355(19):e21.

\section{Managing clinical records}

- Joint Commission International. Accreditation Standards for Hospitals. $3^{\text {rd }}$ Ed. 2008.

- Joint Commission International. Manuale interpretazione standard per ospedali e per la sicurezza del paziente. 2009.

- Regione Lombardia. Manuale della cartella clinica. $2^{a}$ Ed. 2007. http://www.comlas.it/documenti/ManualeCartellaClinicadellaRegioneLombardia.pdf

- Roberts JS, Coale JG, Redman RR. A history of the Joint Commission on Accreditation of Hospitals. JAMA 1987; 258(7):936-40. 


\section{Bed side training}

\begin{tabular}{|c|c|c|c|}
\hline Basic professionalism & Optimal professionalism & Excellent professionalism & Distinctive professionalism \\
\hline $\begin{array}{l}\text { - Knowing how to make decisions in a } \\
\text { global manner: questioning and } \\
\text { examining patients, reasoning as to what } \\
\text { they present with, not omitting the } \\
\text { psychodynamic aspects and emotions, } \\
\text { explicit and also implicit willingness, } \\
\text { actual needs, socio-economic and } \\
\text { familial context, possible comorbidities, } \\
\text { functional limitations or cognitive } \\
\text { dysfunctions and alterations of the } \\
\text { emotional sphere } \\
\text { - Knowing how to utilise the methods of } \\
\text { evidence-based medicine (EBM) } \\
\text { Knowing how to identify the difference } \\
\text { between guidelines and diagnostic- } \\
\text { therapeutic paths }\end{array}$ & $\begin{array}{l}\text { - Knowing how to carry out both inductive } \\
\text { and deductive methods of clinical } \\
\text { reasoning } \\
\text { - Knowing the entire path of evidence- } \\
\text { based practise, guidelines, clinical } \\
\text { governance, audit } \\
\text { - Critically evaluating protocols and } \\
\text { knowing how to apply them to the actual } \\
\text { patient } \\
\text { - Knowing how to distinguish statistical } \\
\text { significance from clinical relevance } \\
\text { - Knowing the limits of EBM in Internal } \\
\text { Medicine and its integration with clinical } \\
\text { experience }\end{array}$ & $\begin{array}{l}\text { - Innovating and implementing protocols } \\
\text { - Knowing how to describe the process of } \\
\text { Health Technology Assessment and its } \\
\text { instruments } \\
\text { - Critically evaluating a study protocol } \\
\text { - Applying EBM to actual patients using the } \\
\text { PICO method (patient, intervention, } \\
\text { comparison, outcome) } \\
\text { - Conducting a clinical audit }\end{array}$ & $\begin{array}{l}\text { - Possessing a specific professional } \\
\text { competence-certified according to } \\
\text { excellence criteria - to be made } \\
\text { available - as an added value - to the } \\
\text { local hospital, in the interest of the } \\
\text { patient } \\
\text { - Knowing how to identify and research } \\
\text { the MID (minimally important difference) } \\
\text { or MCID (minimal clinically important } \\
\text { difference) in clinical trials }\end{array}$ \\
\hline
\end{tabular}

\begin{tabular}{|c|c|c|c|}
\hline \multicolumn{4}{|l|}{ Individual behaviour } \\
\hline Basic professionalism & Optimal professionalism & Excellent professionalism & Distinctive professionalism \\
\hline $\begin{array}{l}\text { - Knowing the objectives of the hospital and } \\
\text { participating in the facilitation of pursuing } \\
\text { the above when negotiated and shared } \\
\text { - Having the awareness, that in team work, } \\
\text { in the hospital context: } \\
\text { - the competence and excellence of the } \\
\text { technico-operative acts which have to } \\
\text { guide individual behaviour are reversed } \\
\text { in group behaviour: } \\
\text { - the objective of everyone is not that of } \\
\text { managing personally but of acting so that } \\
\text { the entire group manages to reach the } \\
\text { objects of the hospital; } \\
\text { - the lack of active personal participation } \\
\text { towards the hospital objectives will be } \\
\text { evaluated in meritocratic terms with } \\
\text { reference to reward systems and/or } \\
\text { sanctions } \\
\text { - Knowing how to demonstrate the } \\
\text { avoidance of certain behaviour in the } \\
\text { local organisational context }\end{array}$ & $\begin{array}{l}\text { - Participating in the pursuit of the } \\
\text { negotiated and shared objectives, with } \\
\text { the capacity of supplying information } \\
\text { to the working group } \\
\text { - Knowing how to demonstrate, in an } \\
\text { organisational context, the capacity of } \\
\text { constructive criticism aimed at reaching } \\
\text { shared objectives, congruent with those } \\
\text { of the hospital in which he/she works } \\
\text { - Knowing how to identify a relationship } \\
\text { of openness, explicitness and trust, } \\
\text { comparison-competition on the } \\
\text { - Activelyes participating in the pursuit of } \\
\text { - Kne negotiated objectives and strategies } \\
\text { solution how to propose hypotheses of } \\
\text { represented respect to the criticality }\end{array}$ & $\begin{array}{l}\text { - Knowing how to participate in team work } \\
\text { in terms of: } \\
\text { - Recognition of interdependence with } \\
\text { "others"; } \\
\text { - plurality of interaction and integration; } \\
\text { - perception of reciprocal necessity; } \\
\text { - systematic orientation for exchange } \\
\text { and collaboration } \\
\text { - Knowing how to facilitate, in an } \\
\text { organisational context and considering } \\
\text { different opinions, the attainment of } \\
\text { shared objectives, congruent with } \\
\text { those of the hospital } \\
\text { - Knowing how to create alliances and } \\
\text { synergies, manage and know how to } \\
\text { overcome resistance and opposition } \\
\text { - Documenting the attainment of } \\
\text { objectives }\end{array}$ & $\begin{array}{l}\text { - Knowing how to pursue the shared } \\
\text { objectives of the hospital }\end{array}$ \\
\hline
\end{tabular}


- sharing minimal synergy with the explicit objectives shared by "opposition"

without purpose

- Knowing how to propose a discussion

on criticality

- Actively participating in discussion on

negotiated objectives and strategies

\begin{tabular}{|c|c|c|c|}
\hline \multicolumn{4}{|l|}{ Autonomy at work } \\
\hline Basic professionalism & Optimal professionalism & Excellent professionalism & Distinctive professionalism \\
\hline $\begin{array}{l}\text { - Having passed the initial period, } \\
\text { demonstrating autonomy in carrying } \\
\text { out activities indicated by one's job } \\
\text { description } \\
\text { - Being autonomous in carrying out the } \\
\text { activity indicated, even if with } \\
\text { supervision in the management of } \\
\text { complex cases }\end{array}$ & $\begin{array}{l}\text { - Carrying out specific tasks with the need } \\
\text { for supervision } \\
\text { - Knowing how to point out organisational } \\
\text { criticality on the basis of the specific } \\
\text { professional and the possible hypotheses } \\
\text { of solution }\end{array}$ & $\begin{array}{l}\text { - Training other professionals to carry out } \\
\text { a specific task } \\
\text { - Knowing how to identify the elements } \\
\text { of strength and weakness of a project }\end{array}$ & $\begin{array}{l}\text { - Evaluating the collaborators in an } \\
\text { organisational context } \\
\text { - Possessing a professionalism recognised } \\
\text { at the national level } \\
\text { - Possessing a professionalism recognised } \\
\text { at the international level }\end{array}$ \\
\hline
\end{tabular}

\section{Preparation of general assistance and treatment}

\begin{tabular}{|c|c|c|c|}
\hline Basic professionalism & Optimal professionalism & Excellent professionalism & Distinctive professionalism \\
\hline $\begin{array}{l}\text { - Obtaining and managing the anamnestic } \\
\text { data and useful information in the history } \\
\text { of the patient } \\
\text { - Orienting the diagnostic-therapeutic } \\
\text { course on the basis of anamnestic data } \\
\text { - Describing the active/underlying } \\
\text { comorbidities and problems } \\
\text { - Recognising the principal } \\
\text { physiopathological mechanisms } \\
\text { underlying the clinical picture } \\
\text { identified } \\
\text { - Formulating diagnostic hypotheses and } \\
\text { differential diagnoses } \\
\text { - Interpreting and evaluating clinical, } \\
\text { laboratory and instrumental data } \\
\text { - Determining the most frequent } \\
\text { prognoses and serious pathologies in } \\
\text { internal medicine }\end{array}$ & $\begin{array}{l}\text { - Autonomously carrying out consultation } \\
\text { in other departments } \\
\text { - Autonomously managing patients in other } \\
\text { departments (orthopaedics, surgery, etc.) } \\
\text { - Establishing clinical priorities according to } \\
\text { the comorbidities } \\
\text { - Deciding the diagnostic course } \\
\text { appropriate for the patient (also cost/ } \\
\text { benefit) according to emerging } \\
\text { hypotheses } \\
\text { - Formulating diagnostic hypotheses and } \\
\text { differential diagnoses also in patients with } \\
\text { multiple pathologies and in complex } \\
\text { patients } \\
\text { - Interpreting and clinically evaluating the } \\
\text { clinical laboratory and instrumental data, } \\
\text { also in patients with multiple pathologies } \\
\text { and in complex patients }\end{array}$ & $\begin{array}{l}\text { - Planning management of the patient on } \\
\text { the basis of the prognosis } \\
\text { - Planning management of the patient on } \\
\text { the basis of the MDE (multidimensional } \\
\text { evaluation) } \\
\text { - Planning "off-label" therapies in a } \\
\text { motivated manner congruent with the } \\
\text { laws in force } \\
\text { - Identifying patients who require specific } \\
\text { health education for a better } \\
\text { participation in managing their illness } \\
\text { - Managing protected and difficult } \\
\text { discharges } \\
\text { - Formalising and planning the criteria } \\
\text { which regulate the relationships } \\
\text { between the various specialities and } \\
\text { internal transfers }\end{array}$ & \\
\hline
\end{tabular}


- Proposing appropriate therapy (also cost/benefit) on the basis of available knowledge and efficiency tests

- Furnishing necessary information and communicating the notes of health education, also with the aim of obtaining informed consent

- Communicating the clinical elements necessary to insure continuous assistance, according to clear and comprehensible modalities

- Transferring diagnostic-therapeutic information to the specialist in internal medicine when necessary

- Managing the patient for treatment of acute and/or chronic acute illnesses
- Determining the most frequent diagnoses and serious pathologies in internal

medicine, also for patients with multiple pathologies and complex patients.

- Remodelling the diagnostic therapeutic path on the basis of new data to identify the factors conditioning the prognosis

- Carrying out a multidimensional

evaluation (MDE)

- Personalising the appropriate therapy and verifying the congruity also on the basis of the MDE and internal medicine

pathologies in patients with multiple

pathologies and complex patients

- Involving the patient and/or family

members in managing the process of the treatment

- Communicating, according to clear and comprehensible modalities, the clinical elements necessary to insure institutional continuity, even in the most complex cases, both for clinical and social problems

- Communicating diagnostic-therapeutic information to the specialist where necessary, also in situations which are not the competence of the specialist in

internal medicine

- Managing patients for:

- the treatment of acute and/or chronic acute illnesses and different and

complex syndromes

- palliative treatment

- perioperative treatment

- Planning the management of patients for the treatment of illnesses from admission to discharge and institutional continuity 
Complex Patient

\begin{tabular}{|c|c|c|c|}
\hline Basic professionalism & Optimal professionalism & Excellent professionalism & Distinctive professionalism \\
\hline $\begin{array}{l}\text { - Stratifying the risks and selecting the } \\
\text { main points } \\
\text { - Defining the priorities and hierarchy of } \\
\text { needs } \\
\text { - Utilising the instruments of evaluation of } \\
\text { functional dependence } \\
\text { - Selecting the treatment objectives and } \\
\text { the appropriate pharmacological } \\
\text { therapy } \\
\text { - Defining which institutional setting is } \\
\text { desirable for the patient } \\
\text { - Making decisions even in situations of } \\
\text { uncertainty } \\
\text { - Utilising "evidence-based" tests of } \\
\text { efficacy for the actual patient } \\
\text { - Recognising the presence of a pathology } \\
\text { which requires isolation of the patient }\end{array}$ & $\begin{array}{l}\text { - Carrying out a multidimensional } \\
\text { evaluation (MDE) in different } \\
\text { institutional settings: } \\
\text { - in hospital } \\
\text { - in the doctor's office (consultations) } \\
\text { - in the follow-up regarding institutional } \\
\text { continuity } \\
\text { - in post-acute departments } \\
\text { - in residential structures } \\
\text { - in other departments/services } \\
\text { - Knowing how to recognise the different } \\
\text { dominions of the complexity and } \\
\text { differentiate the concepts of } \\
\text { - clinical complexity } \\
\text { - institutional nursing complexity } \\
\text { - management complexity } \\
\text { - Utilising instruments for evaluating } \\
\text { comorbidities } \\
\text { - Programming stratification of the } \\
\text { intensity of treatment in relation to the } \\
\text { multidimensional evaluation } \\
\text { - Programming stratification of the } \\
\text { intensity of treatment in relation to the } \\
\text { prognostic stratification } \\
\text { - Utilising the instruments of evaluation of } \\
\text { fragility } \\
\text { - Utilising 'evidence-based' tests of } \\
\text { efficacy for the actual patient } \\
\text { - Defining the possible prognostic future of } \\
\text { the patient on the basis of the decisions } \\
\text { taken } \\
\text { - Carrying out prognostic stratification }\end{array}$ & & \\
\hline
\end{tabular}

\section{Frail Patient}

\begin{tabular}{|c|c|c|c|}
\hline Basic professionalism & Optimal professionalism & Excellent professionalism & Distinctive professionalism \\
\hline $\begin{array}{l}\text { - Knowing how to describe the phenotype } \\
\text { of a "fragile" patient } \\
\text { - Knowing how to differentiate a } \\
\text { "robust" patient from a "fragile" } \\
\text { patient }\end{array}$ & $\begin{array}{l}\text { - Knowing how to use at least one of the } \\
\text { principal methods of evaluation of the } \\
\text { fragile patient } \\
\text { - Knowing how to identify the clinical } \\
\text { criteria of the evaluation of sarcopenia }\end{array}$ & $\begin{array}{l}\text { - Participating in programs of "disease- } \\
\text { case management" in the hospital } \\
\text { belonging to this program }\end{array}$ & $\begin{array}{l}\text { - Directly carrying out procedures for the } \\
\text { evaluation of sarcopenia } \\
\text { (impedancemetry, DEXA (dual energy } \\
\text { X-ray absorptiometry), measuring } \\
\text { physical performance, speed gait, etc.) }\end{array}$ \\
\hline
\end{tabular}


- Making decisions on the basis of a prognostic-functional evaluation of the patient

- Knowing how to identify and classify the patient at risk for repeated hospital admission, "frequent user", the patient at risk for "difficult discharge"

- Knowing how to plan discharge right from the moment of admission to hospital
- Knowing how to identify the path of protected discharge on the basis of multidimensional evaluation

- Describing the prognostic elements

predictive of unfavourable results after discharge from hospital

\section{Critical Patient}

\begin{tabular}{|c}
\hline Basic professionalism \\
\hline - Evaluating, managing and treating the
\end{tabular}
acute, unstable critical patient

- Oxygen therapy with goggles and Venturi

mask according to guidelines

- Proposing the laboratory and

instrumental testing necessary in an emergency, urgency, extended urgency and ordinary conditions, according to

appropriate criteria

- Knowing how to differentiate the intensity of treatment necessary

- Recognising significant changes in the condition of the patient and making opportune consequent decisions

- Knowing how to carry out ACLS (advanced cardiac life support)

- Having the competence of carrying out oxygen therapy and using a Venturi mask - Having basic competence for using a defibrillator monitor and external PM (pacemaker)

- Having BLS-D (basic life support-

defibrillation) certification

- Obtaining informed consent for the diagnostic-therapeutic and institutional procedures necessary

- Obtaining, if available, patient instructions as to reanimation procedures

$$
\text { Optimal professionalism }
$$

- Proposing the testing necessary for the eventual negative evolution of the clinical picture

- Knowing how to use telemetry when available

- Programming actions connected to the change of patient status

- Managing the initial phases of principal haematological emergencies while waiting for transfer or specialistic consultation
Excellent professionalism

- Knowing, applying and implementing the instruments of evaluation of the critical patient in various nosological spheres such as, e.g.

- Ehrenwerth classification per transfer of patients

- APACHE II-III ASA (Acute and chronic health evacuation-American Society of Anesthesiologists)

- SAPS II-III (Simplified Acute Physiology Score)

- OMEGA score, APS (Acute Physiology Score), EWSS (Early Warning Scoring System)

- TISS (Therapeutic intervention scoring system), McCabe

- SOFA (Sepsis-related organ failure assessment)

- LOD (Logistic organ Dysfunction

System), ASA

- MPM (Mortality prediction model)

- PSI (Physiology stability index)

- AVPU (alert, vocal, pain, unresponsive) GCS (Glasgow Coma Scale)-MMS

(Mini Mental State)

- NYHA (New York Heart Association)KILLIP-LOWN

- TIMI (Thrombolysis in Myocardial

Infarction) score

- BTS (British Thoracic Society)-FINE PORT for CAP (community-acquired pneumonia)
Distinctive professionalism

- Knowing how to use the rhino-pharingeal cannula and extra-glottic protection

(EGP), e.g. laryngeal tube alternatively

to orotracheal intubation (OTI)

- Knowing how to carry out OTI

- Knowing how to carry out ALS

(advanced life support)

- Know how to carry out ATLS

(advanced trauma life support)

- Know how to carry out ACLS 
- Kelly-Matthay scale for neurological state during respiratory insufficiency

- O.P.Q.R.S.T. (onset, provokes, quality, radiates, severity) for thoracic pain

- Banks, Agarwall, Pitchumoni, Ranson, IMRIE, Glasgow, Atlanta, Salles,

Balthazar criteria for acute pancreatitis

- ROCKALL SCORE for digestive

haemorrhage

- CLASSI ACS (acute coronoary syndrome)

for haemorrhagic shock

- CIRS (critical incident reporting

system), CHARLSON for comorbidity

- NIHSS (National Institutes of Health

Stroke Scale), CNS (Canadian

Neurological Score), SSS (Scandanavian

Stroke Scale), BSA (bedside swallowing

assessment), BARTHEL, RANKIN, FIM

(functional independency

measurement scale), SPREAD (stroke

prevention and educational awareness diffusion) for stroke

- WFNS (World Federation of Neurological

Surgeons) score

- Hunt-Hess score for subarachnoid

haemorrhage

- WELLS criteria for DVT /Deep Venous

Thrombosis)

- CHILD-TURCOTTE-PUGH score for

hepatic insufficiency

- Trey-Davidson score for hepatic encephalopathy

- DIC (Disseminated Intravascular

Coagulation) score for disseminated

intravascular coagulation

- EHRA (European Heart Rhythm

Association) AF (atrial fibrillation)

score, CHA2-DS2-VASc score, OBRI

(Outpatient bleeding risk index), HAS-

BLED bleeding risk score (Hypertension, Abnormal renal/liver function, Stroke,

Bleeding history or predisposition,

Labile international normalized ratio,

Elderly ( $>65$ years), Drugs/alcohol

concomitantly) 
for evaluation of the patient and

thrombotic/haemorrhagic risk in the

course of atrial fibrillation, etc.

- Explaining (teaching) the tests correlated

to the signs and symptoms predictive of

a negative evolution

- Alert the medical staff assisting the

patient (nurse/ resident) regarding the signs/symptoms and testing predictive of a negative evolution

\begin{tabular}{|c|c|c|c|}
\hline Basic professionalism & Optimal professionalism & Excellent professionalism & Distinctive professionalism \\
\hline $\begin{array}{l}\text { - Utilising monitoring systems of basic } \\
\text { parameters } \\
\text { - Knowing how to carry out diagnosis and } \\
\text { therapy in situations of urgency/ } \\
\text { emergency: APE (acute pulmonary } \\
\text { edema), SCA (sudden cardiac arrest), } \\
\text { serious arrhythmias, ventilo-respiratory } \\
\text { insufficiency, carbonarcotic coma, } \\
\text { diabetic ketoacidosis and hyperosmolar } \\
\text { syndrome, hypoglycaemic coma and } \\
\text { tacidaemia, electrolytic disturbances, } \\
\text { hepatic coma, digestive haemorrhage, } \\
\text { acute pancreatitis, sepsis, stroke, shock, } \\
\text { delirium, syncope, convulsive crises, } \\
\text { malignant hyperthermia, transfusional } \\
\text { reactions, drug and/or pharmaceutical } \\
\text { overdose, acute renal insufficiency, } \\
\text { haemorrhagic syndromes, acute } \\
\text { haematological syndromes, acute painful } \\
\text { syndromes, psychoses, acute thoracic and } \\
\text { abdominal pain syndromes, MOF (multiple } \\
\text { organ failure), etc. } \\
\text { - Carrying out severity, risk and prognostic } \\
\text { stratification evaluation in different } \\
\text { pathologies of the acute critical patient }\end{array}$ & $\begin{array}{l}\text { - Knowing how to evaluate non-invasive } \\
\text { multiparametric monitoring of the } \\
\text { patient } \\
\text { - Knowledgably utilising the principal } \\
\text { severity indices/scores of the critical } \\
\text { patient }\end{array}$ & $\begin{array}{l}\text { - Using the Boussignac valve, C-PAP and Bi- } \\
\text { level } \\
\text { - Knowing, applying and implementing the } \\
\text { instruments of evaluation of the critical } \\
\text { patient in various nosological spheres } \\
\text { such as, e.g. } \\
\text { - Ehrenwerth classificaton per transfer of } \\
\text { patients } \\
\text { - APACHE II-III } \\
\text { - ASA } \\
\text { - SAPS II-III } \\
\text { - OMEGA, APS, EWSS } \\
\text { - TISS, McCabe } \\
\text { - SOFA } \\
\text { - LOD, ASA } \\
\text { - MPM } \\
\text { - NYHA-KILLIP-LOWN } \\
\text { - TIMI score } \\
\text { - BTS-FINE PORT for CAP } \\
\text { - Kelly-Matthay scale for neurological } \\
\text { state during respiratory insufficiency } \\
\text { - O.P.Q.R.S.T. for thoracic pain } \\
\text { - Banks, Agarwall, Pitchumoni, Ranson, } \\
\text { IMRIE, Glasgow, Atlanta, Salles, } \\
\text { Balthazar criteria for acute pancreatitis }\end{array}$ & $\begin{array}{l}\text { - Capacity of carrying out OTI (orotracheal } \\
\text { intubation) } \\
\text { - Capacity of managing invasive ventilation } \\
\text { - Knowing how to manage the critical area }\end{array}$ \\
\hline
\end{tabular}




\begin{tabular}{|c|c|c|c|}
\hline $\begin{array}{l}\text { - Utilising the instruments of severity, risk } \\
\text { and prognostic stratification evaluation in } \\
\text { different pathologies of the critically } \\
\text { acute patient (MEWS (mosified early } \\
\text { warning score), NIHSS, Glasgow, ABCD } \\
\text { (Age,blood pressure, clinical ffeatures, } \\
\text { duration of symptoms and diabetes), } \\
\text { Apache, etc.) }\end{array}$ & & $\begin{array}{l}\text { - ROCKALL SCORE for digestive } \\
\text { haemorrhage } \\
\text { - CLASSI ACS for haemorrhagic shock } \\
\text { - CIRS, CHARLSON for comorbidity } \\
\text { - nihss, cns, sss, bsa, barthel, rankin, fim, } \\
\text { SPread for stroke } \\
\text { - WFNS score } \\
\text { - Hunt-Hess score for subarachnoid } \\
\text { haemorrhage } \\
\text { - WELLS criteria for TVP } \\
\text { - CHILD-TURCOTTE-PUGH score for } \\
\text { hepatic insufficiency } \\
\text { - Trey-Davidson score for hepatic } \\
\text { encephalopathy } \\
\text { - DIC score for disseminated intravascular } \\
\text { coagulation } \\
\text { - EHRA AF score, CHA2-DS2-VASc score, } \\
\text { OBRI, HAS-BLED bleeding risk score for } \\
\text { evaluation of the patient and } \\
\text { thrombotic/haemorrhagic risk in the } \\
\text { course of atrial fibrillation, etc. } \\
\text { - Knowing how to carry out bedside } \\
\text { internistic ecography (abdomen, heart, } \\
\text { vessels) } \\
\text { Knowing how to insert a central vein } \\
\text { catheter (CVC) }\end{array}$ & \\
\hline \multicolumn{4}{|c|}{ Acute Coronary NSTEMI Syndrome } \\
\hline Basic professionalism & Optimal professionalism & Excellent professionalism & Distinctive professionalism \\
\hline $\begin{array}{l}\text { - Knowing the etiopathogenetic and } \\
\text { physiopathological aspects } \\
\text { - Knowing how to recognise the ECGrafic } \\
\text { signs of ischemia, lesions and necrosis } \\
\text { - Obtaining a complete anamnesis } \\
\text { (including pharmacological) and carrying } \\
\text { out an objective exam aimed at possible } \\
\text { etiological pictures } \\
\text { - Know the modalities, symptoms and signs } \\
\text { of atypical presentation of IMA (internal } \\
\text { mammary artery)/SCA } \\
\text { - Recognising the principal differential } \\
\text { diagnoses, such as non-ischemic cardiac } \\
\text { (e.g. pericarditis) or non-cardiac } \\
\text { (esophageal spasm) pathologies }\end{array}$ & $\begin{array}{l}\text { - Knowing how to evaluate, in an } \\
\text { appropriate way in clinical practice, the } \\
\text { significance (and limits) of the different } \\
\text { biomarkers of myocardial damage } \\
\text { - Knowing how to apply the O.P.Q.R.S.T. } \\
\text { method for the evaluation of thoracic } \\
\text { pain } \\
\text { - Knowing how to utilise the classification } \\
\text { of the Canadian Society of Cardiology in } 4 \\
\text { stages of gravity of the angor } \\
\text { - Knowing and applying the risk scores for } \\
\text { identifying patients with a serious } \\
\text { prognosis } \\
\text { - Organising assistance for patients at high } \\
\text { risk for sudden death }\end{array}$ & $\begin{array}{l}\text { - Participating in initiatives of } \\
\text { improvement of quality for efficacious } \\
\text { prevention, early recognition and AUDIT } \\
\text { reduction, andportfolio of possible } \\
\text { complications } \\
\text { - Knowing how to carry out thrombolysis } \\
\text { in indicated cases } \\
\text { - Periodic reporting of the updating } \\
\text { of the scientific literature on the } \\
\text { topic } \\
\text { - Coordinating/participating in a } \\
\text { multidisciplinary team involved in } \\
\text { the management of SCA/NSTEMI } \\
\text { (non-ST-elevation myocardial } \\
\text { infarction) }\end{array}$ & $\begin{array}{l}\text { - Carrying out an echo-cardiogram for the } \\
\text { evaluation of total and segmentary } \\
\text { kinesis }\end{array}$ \\
\hline
\end{tabular}


- Insuring adequate venous access and carrying out haemodynamic stabilisation manoeuvres where necessary

- Requesting diagnostic and monitoring

evaluation tests

- Knowing the procedures for diagnosis and and the methodology for treatment of possible complications and

antiaggregating and anticoagulating treatment

- Carrying out electric shock treatment (DC shock) for malignant hyperkinetic arrhythmia

- Knowing the mechanism of action and the indications of the medications to use

- Recognising the clinical conditions which make immediate transfer into intensive or haemodynamic care necessary,

interacting with the respective medical specialist (e.g. cardiogenic shock)

- Knowing how to manage the infusion of

nitrates and dopamine

- Planning discharges favouring

institutional continuity

- Recognising the signs and symptoms

indicative of instability of the clinical picture

- Recognising the clinical conditions of stabilisation and the possible discharge of the patient and/or transfer to another institutional setting

- Communicating the etiological aspects, prognosis, diagnostic and therapeutic indications, and follow-up programs to the patients and their families,

requesting informed consent
- Knowing how to identify high risk patients and, of these, evaluate, on the basis of total clinical conditions, those on whom to begin coronary revascularisation procedures

- Carrying out a clinico-laboratory and imaging technique synthesis in order to formulate a comprehensive treatment plan

- Evaluating the advantages/ disadvantages relative to

pharmacological and invasive treatments - Carrying out a prognostic risk stratification by means of knowledge of specific scores (TIMI-GRACE (Global Registry of Acute Coronary Events)PURSUIT (Platelet glycoprotein Ilb/IIla in Unstable angina: Receptor Suppression Using Integrilin)

- Planning discharges favouring institutional continuity
- Actually coordinating/participating in the writing of guidelines and

institutional paths in order to render efficient and efficacious assistance to patients with SCA/NSTEMI 
Cardiac Arrhythmia

Basic professionalism
- Knowing how to carry out diagnostic

evaluation (reading of an ECG)

- Knowing how to identify the most

common (e.g. atrial fibrillation) and non-

complex arrhythmias

- Identifying and recognising the

modalities of clinical presentation of the

most common arrythymias, obtaining a

specific anamnesis and carrying out an

objective test (with particular attention

to haemodynamic stability)

- Knowing anti-arrythymic medications, according to the Vaughan-Williams classification, and their mechanism of action

- The capacity of carrying out electric defibrillation in emergency/urgency situations

- Requesting appropriate exams for the evaluation of arrythmias (including

Holter ECG, telemetry, etc.)

- Carrying out a prognostic evaluation of arrhythmic risk (ECG characteristics, cardiac conditions and comorbidities), identifying the level of treatment required

- Knowing the medications, metabolic conditions and comorbidities which can set off arrhythmias

- Knowing how to carry out pharmacological therapy to reduce cardiac frequency during AF (atrial fibrillation or other supraventricular hyperkinetic arrhythmias in

haemodynamically stable patients

- Knowing how to recognise patients candidates for a PM (pacemaker)

- Early recognition of high risk arrhythmias which require urgent specialistic intervention

\section{- Knowing the Lown classification of} arrythymias

- Knowing how to recognise, according to the EHRA criteria, the severity of symptoms in case of atrial fibrillation

- Knowing how to prescribe therapy for the most common cardiac arrhythmias, even in the most complex cases, and in multipathological and multitreated patients

- Knowing how to utilise telemetry in subintensive areas, when available

- Knowing how to recognise patients who need a cardiologist for the management of complex arrhythmias

- Knowing how to identify the patients who are capable of managing "pill in the pocket" therapy

- Knowing how to manage pharmacological therapy for a patient who presents

torsade de pointe (paroxysmal

ventricular tachycardia)

- Communicating the diagnosis, prognosis and treatment plan after discharge to the patient and family members, giving information regarding medications and procedures to put into effect

\section{- Knowing how to interpret the most}

complex tracings of an ECG

(electrocardiogram)

- Knowing how to use a defibrillator with

a trans-thoracic PM (pacemaker)

- Knowing how to recognise patients who are candidates for left atrial electric ablation 
- Knowing the mechanisms of action,

indications and contraindications of anti-

arrhythmic medications

- Choosing the therapeutic protocol of the

principal cardiac arrhythmias according

to evidence-based medicine

- Communicating the diagnosis, prognosis and treatment plan after discharge to the patient and family members, giving information regarding medications and procedures to put into effect

- Activating a multidisciplinary and

multiprofessional approach, according the the logic of disease management in order to facilitate discharge and improve the quality of life

- Utilising the evidence-based

recommendations for diagnosis, therapy and monitoring of the principal cardiac arrhythmias

\begin{tabular}{|c|c|c|c|}
\hline \multicolumn{4}{|l|}{ Heart Failure } \\
\hline Basic professionalism & Optimal professionalism & Excellent professionalism & Distinctive professionalism \\
\hline $\begin{array}{l}\text { - Knowing the risk factors for heart failure; } \\
\text { knowing how to apply and use the Killip } \\
\text { classification } \\
\text { - Knowing stratification } \\
\text { - Knowing diagnostic criteria and how to } \\
\text { reach a differential diagnosis } \\
\text { - Recognising the underlying aetiology } \\
\text { - Identifying precipitating factors } \\
\text { - Putting the patient under the care of the } \\
\text { respective medical specialist for the } \\
\text { management of advanced or refractory } \\
\text { cardiopathy } \\
\text { - Evaluating the presence of comorbidities } \\
\text { and their clinical-prognostic } \\
\text { significance } \\
\text { - Utilising the scores of prognostic } \\
\text { stratification } \\
\text { - Prescribing therapy to slow the } \\
\text { progression of cardiopathy }\end{array}$ & $\begin{array}{l}\text { - Managing refractory heart failure } \\
\text { - Imposing a monitoring and follow-up } \\
\text { program, according to the protocol of } \\
\text { disease management } \\
\text { - Knowing the indicators of good clinical } \\
\text { practice } \\
\text { - Prescribing therapy to slow the } \\
\text { progression of cardiopathy } \\
\text { - Selecting patients to propose } \\
\text { coronarography } \\
\text { - Selecting patients to propose aortic } \\
\text { contra-pulsation in a subintensive area } \\
\text { - Selecting patients to propose the } \\
\text { application of an LVAD (left ventricular } \\
\text { assist device) } \\
\text { - Management of refractory CS } \\
\text { - Selecting patients to propose the implant } \\
\text { of a bi-ventricular PM for cardiac } \\
\text { resynchronisation }\end{array}$ & $\begin{array}{l}\text { - Knowing how to carry out a basic trans- } \\
\text { thoracic ecography } \\
\text { - Acquisition of other diagnostic and } \\
\text { therapeutic instrumental techniques } \\
\text { (impedancemetry, BNP (Brain matiuretic } \\
\text { peptide), etc.) } \\
\text { - Have ACLS (Advance cardiovascular life } \\
\text { support) certification } \\
\text { - Knowing how to carry out NIV } \\
\text { - Selecting potential candidates for } \\
\text { myocardiac biopsy }\end{array}$ & $\begin{array}{l}\text { - Knowing how to carry out a TEE (trans- } \\
\text { esophagheal echocardiography) } \\
\text { - Managing ultra-filtration }\end{array}$ \\
\hline
\end{tabular}


- Evaluating the indications and contraindications for non-invasive ventilation with positive PEEP (Positive end-expiratory pressure)

- Recognising the indications for the use of NIV (non-invasive ventilation) techniques in the acute patient

- Recognising the indications for therapy

for obstructive apnee

- Planning the discharge of patients with

CS and writing an adequate letter of discharge

- Knowing how to manage assistance to terminal patients
- Selecting patients to propose haemofiltration

- Carrying out non-invasive ventilation with positive PEEP

- Selecting patients to propose an ICD (Implantable cardioverter-defibrillator) for secondary prevention

- Selecting patients who could be potential candidates for a heart transplant

\section{Stroke}

\begin{tabular}{|c|}
\hline Basic professionalism \\
\hline - Carrying out general physical
\end{tabular}
examination

- Reaching a differential diagnosis

- Carrying out neurological tests

- Carrying out support therapy when

the use of thrombolysis is excluded

- Evaluating and monitoring vital

parameters

- Knowing the investigations necessary

for identifying emboligenic sources

- Knowing the inclusion and exclusion

criteria for thrombolysis

- Defining the necessary postures

- Evaluating and managing risks and

complications

- Defining treatment according to

guidelines

- Correctly and opportunely interacting

with other specialists

- Knowing how to manage assistance to

terminal patients
Optimal professionalism

- Utilising the evaluation scales for stroke

(e.g. Cincinnati pre-hospital scale, GCS,

NIH Stroke Scale, 5-NIHSS, Canadian

Neurological Scale, Scandinavian Stroke Scale, Rankin, Barthel, Greenfield

comorbidity index, etc.)

- Knowing how to clinically differentiate an ischemic from a haemorrhagic stroke - Knowing how to carry out the diagnosis of the site of an ischemic stroke, according to the OCSP (Oxfordshire Community

Stroke Project) criteria

- Carrying out prognostic stratification on the basis of the site of the lesion (CT, PACS (partial anterior circulation stroke), PDS (progressive deterioration scale), LACS (lacunar stroke)), according to mortality and functional dependence

- Prescribing the necessary aids and assistance and discuss neuroradiological data (CT (computed tomography), brain and trunk NMR (nuclear magnetic resonance)

- Carrying out peripheral thrombolysis (when authorised)
Distinctive professionalism

- Carrying out echocolordoppler SAT

- Carrying out transcranial ecodoppler

- Knowing how to read an EEG 


\begin{tabular}{|c|c|c|c|}
\hline \multicolumn{4}{|l|}{ Brain Ischemia } \\
\hline Basic professionalism & Optimal professionalism & Excellent professionalism & Distinctive professionalism \\
\hline $\begin{array}{l}\text { - Knowing how to identify a TIA } \\
\text { - Knowing how to interpret an ECG } \\
\text { - Knowing how to recognise the conditions } \\
\text { which can be confused with a TIA } \\
\text { (transient ischemic attack): } \\
\text { - EPILEPTIC CRISES } \\
\text { - SYNCOPES } \\
\text { - LIPOTHYMY } \\
\text { - HAEMICRANIA WITH AURA } \\
\text { - MENIERE'S SYMPTOM } \\
\text { - TRANSITORY GLOBAL AMNESIA } \\
\text { - PERIODIC PARALYSIS WITH DISKALIEMIA } \\
\text { - HYPOGLYCAEMIC CRISES } \\
\text { - NARCOLEPSY } \\
\text { - CATALEPSY } \\
\text { - SENSORY DISORDER } \\
\text { - HYPERVENTILATION } \\
\text { - HYSTERIA } \\
\text { - CEREBRAL HAEMORRHAGES } \\
\text { - SUBDURAL HAEMATOMA } \\
\text { - CEREBRAL NEOPLASIAS } \\
\text { - Knowing how to propose a complete } \\
\text { diagnostic procedure } \\
\text { - Knowing how to propose the most } \\
\text { appropriate antiaggregant therapy } \\
\text { (individual or in association) } \\
\text { - Knowing how to propose OAT (oral } \\
\text { anticoagulant therapy) when indicated } \\
\text { and appropriate } \\
\text { - Knowing how to intervene on risk factors } \\
\text { and associated comorbidities }\end{array}$ & $\begin{array}{l}\text { - Knowing how to carry out prognostic } \\
\text { risk for stroke stratification at } 7 \text { days, } \\
\text { according to the Rothwell et al. } \\
\text { ABCD and ABCD2 score } \\
\text { - Knowing how to plan the timing of the } \\
\text { necessary tests on the basis of calculated } \\
\text { risk for stroke (low, medium, high) }\end{array}$ & $\begin{array}{l}\text { - Knowing how to propose critical } \\
\text { intervention for early disobstruction } \\
\text { in the presence of carotid stenosis } \\
\text { - Knowing how to interpret and discuss } \\
\text { neuroradiological data (CT, brain and } \\
\text { trunk NMR) } \\
\text { - Knowing how to send patients with } \\
\text { suspected patency of the oval foramen } \\
\text { who are candidates for transcatheter } \\
\text { closure to a specialist } \\
\text { - Knowing how to select patients with } \\
\text { patency of the oval foramen who are } \\
\text { candidates for transcatheter closure }\end{array}$ & $\begin{array}{l}\text { - Knowing how to carry out an echodoppler } \\
\text { of the epiaortic vessels } \\
\text { - Knowing how to carry out } \\
\text { ecocardiography }\end{array}$ \\
\hline
\end{tabular}


COPD - Chronic obstructive pulmonary Disease

\begin{tabular}{|c|c|c|c|}
\hline Basic professionalism & Optimal professionalism & Excellent professionalism & Distinctive professionalism \\
\hline $\begin{array}{l}\text { - Recognising the stratification of the } \\
\text { illness according to the most accredited } \\
\text { guidelines GOLD (Global Initiative for } \\
\text { Chronic Obstructive Lung Disease) } \\
\text { - Knowing how to modulate basic chromic } \\
\text { therapy on the basis of stratification of } \\
\text { the severity of the illness } \\
\text { - Diagnosing and treating acute } \\
\text { recurrences } \\
\text { - Knowing how to differentiate the } \\
\text { patients to propose for intensive therapy } \\
\text { treatment } \\
\text { - Identify the indications and } \\
\text { contraindications for NIV (non-invasive } \\
\text { ventilation) }\end{array}$ & $\begin{array}{l}\text { - Knowing how to evaluate FEV-1 (forced } \\
\text { expiratory volume in the } 1^{\text {st }} \text { second) } \\
\text { - Knowing how to identify the conditions of } \\
\text { non-reversible obstruction of the airways } \\
\text { - Considering comorbidities in the } \\
\text { prognosis and therapy } \\
\text { - Knowing how to apply the Kelly-Matthay } \\
\text { Scale to evaluate the neurological state } \\
\text { - Carrying out, when possible, functional } \\
\text { tests such as, for example, the Six } \\
\text { minute walking test }\end{array}$ & $\begin{array}{l}\text { - Knowing how to evaluate the percentage } \\
\text { value of post-broncodilator VEMS (Virtual } \\
\text { Expert Mass Spectometrist) with respect } \\
\text { to the theoretical value } \\
\text { - Knowing how to utilise the instruments } \\
\text { available for evaluating state of health } \\
\text { and quality of life in COPD (e.g. St. } \\
\text { George Respiratory Questionnaire) } \\
\text { - Knowing how to evaluate the BODE } \\
\text { (Body-Mass Index, Airflow Obstruction, } \\
\text { Dyspnea, Exercise Capacity) index for } \\
\text { the prognostic stratification of patients } \\
\text { and evaluation of the probability of } \\
\text { hospitalisation }\end{array}$ & $\begin{array}{l}\text { - Knowing how to carry out spirometry, } \\
\text { by measuring lung volume, diffusion } \\
\text { of CO and haematic gases } \\
\text { - Knowing how to manage NIV in COPD } \\
\text { with respiratory insufficiency in the } \\
\text { indicated cases } \\
\text { - Knowing how to carry out OTI and } \\
\text { knowing the relative indications } \\
\text { - Knowing how to manage invasive } \\
\text { ventilation }\end{array}$ \\
\hline
\end{tabular}

\begin{tabular}{|c|c|c|c|}
\hline \multicolumn{4}{|l|}{ Community pneumonia } \\
\hline Basic professionalism & Optimal professionalism & Excellent professionalism & Distinctive professionalism \\
\hline $\begin{array}{l}\text { - Carrying out prognostic stratification and } \\
\text { evaluation of severity } \\
\text { - Choosing the most appropriate } \\
\text { specific and empiric antibiotic } \\
\text { therapy on the basis of the institutional } \\
\text { setting, and the age and condition } \\
\text { of the patient: } \\
\text { - Outpatient }<40 \text { yrs of age, } \\
\text { immunocompetent } \\
\text { - Patient }<60 \text { yrs of age, } \\
\text { immunocompetent or with } \\
\text { comcomitant pathologies } \\
\text { - Patient }>60 \text { yrs of age or with } \\
\text { comcomitant pathologies } \\
\text { - Hospitalised patient } \\
\text { - Patient in critical condition } \\
\text { - Patient with structural pulmonary } \\
\text { illnesses } \\
\text { - Patient allergic to penicillin } \\
\text { - Suspected aspiration }\end{array}$ & $\begin{array}{l}\text { - Knowing how to opportunely carry out } \\
\text { "switching" of therapy }\end{array}$ & $\begin{array}{l}\text { - Knowing how to interpret the results of } \\
\text { bronchoalveolar lavage (BAL) } \\
\text { - Knowing how to evaluate and manage } \\
\text { cases of possible BOOP-Broncholitis } \\
\text { obliterans-organzing pneumonia }\end{array}$ & $\begin{array}{l}\text { - Knowing how to carry out OTI } \\
\text { - Knowing how to manage invasive } \\
\text { ventilation } \\
\text { - Knowing how to carry out BAL }\end{array}$ \\
\hline
\end{tabular}


- Selecting necessary and adequate

cultural tests

- Choosing the most appropriate specific

and empiric antibiotic therapy for the

common and critical patient

- Carrying out monitoring and indications

for follow-up

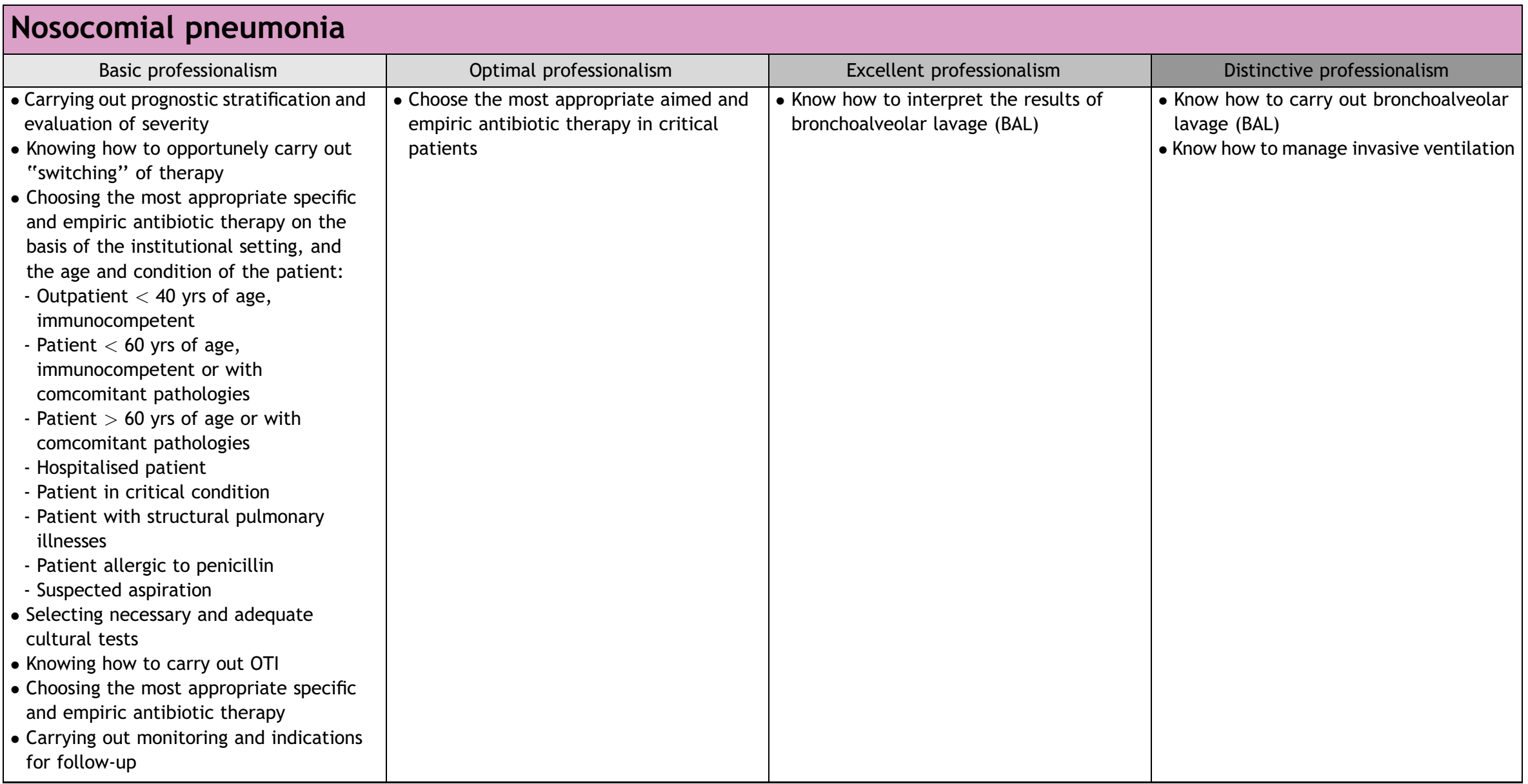




\begin{tabular}{|c|c|c|c|}
\hline \multicolumn{4}{|l|}{ Anaemia } \\
\hline Basic professionalism & Optimal professionalism & Excellent professionalism & Distinctive professionalism \\
\hline $\begin{array}{l}\text { - Knowing how to identify anaemia in a } \\
\text { patient, the classify the anaemia and its } \\
\text { most frequent epidemiological causes } \\
\text { - Knowing how to differentiate siderpenic } \\
\text { anaemia from anaemia from chronic } \\
\text { illness (ACD-anaemia of chronic disease) } \\
\text { - Knowing how to identify comorbidities } \\
\text { and important factors in determinism/ } \\
\text { prognosis of anaemia } \\
\text { - Managing admission and discharge of } \\
\text { patients } \\
\text { - Knowing the diagnostic testing necessary } \\
\text { for the basic study of anaemia } \\
\text { - Knowing how to carry out martial therapy } \\
\text { (evaluation of iron requirement, martial } \\
\text { state, absolute and/or functional lack of } \\
\text { iron possible excess, evaluation of } \\
\text { reserves, modalities of supplementation, } \\
\text { etc.) } \\
\text { - Knowing how to evaluate and manage the } \\
\text { possible adverse complications/ } \\
\text { reactions, ABO incompatibility } \\
\text { correlated to haemotransfusion } \\
\text { - Efficient utilisation of blood and } \\
\text { haemoderivatives } \\
\text { - Knowing how to manage the blood } \\
\text { transfusion unit and the relative } \\
\text { modalities on the basis of professional } \\
\text { responsibility } \\
\text { - Knowing how to manage assistance to } \\
\text { terminal patients }\end{array}$ & $\begin{array}{l}\text { - Knowing the most up-to-date indications } \\
\text { and guidelines on the modalities for the } \\
\text { prescription and administration of } \\
\text { medications requiring specific } \\
\text { procedures (e.g. antifungal, antiviral, } \\
\text { monoclonal antibodies } \\
\text { - Knowing how to select patients who are } \\
\text { able to undergo EPO therapy } \\
\text { - Directing patients to one of the following } \\
\text { specialistic areas: lymphomas, } \\
\text { leukaemia, multiple myeloma, } \\
\text { myeloproliferative diseases, halogenic } \\
\text { and autologous transplants, innovative } \\
\text { cellular therapies } \\
\text { - Treatment in internal medicine } \\
\text { treatment, even in more complex cases } \\
\text { and in multipathological patients } \\
\text { - Diagnostic picture, even in more complex } \\
\text { cases and in multipathological patients } \\
\text { - Knowing how to differentiate the } \\
\text { different forms available and the } \\
\text { respective posologies of iron } \\
\text { - oral formulation: ferrous fumarate, } \\
\text { gluconate, sulphate, long-acting } \\
\text { sulphate } \\
\text { - Iv/im formulation: ferrous dextran, } \\
\text { ferrous sucrose } \\
\text { - Knowing how to interpret the results of } \\
\text { lymphocyte typification } \\
\text { - Knowing how to manage anaemia with } \\
\text { the diagnostic hypothesis of } \\
\text { myelodysplasia }\end{array}$ & $\begin{array}{l}\text { - Knowing how to administer growth } \\
\text { factors for the mobilisation of CSE and } \\
\text { cellular reconstruction } \\
\text { - Management of the following pathologies } \\
\text { and complications: lymphomas, } \\
\text { leukaemia, multiple myeloma, } \\
\text { myeloproliferative diseases, halogenic } \\
\text { and autologous transplants, innovative } \\
\text { cellular therapies }\end{array}$ & $\begin{array}{l}\text { - Reference for opinions on the } \\
\text { management of complex and/or } \\
\text { controversial cases in the sphere of one } \\
\text { of the following specialistic areas: } \\
\text { - lymphomas } \\
\text { - leukaemia } \\
\text { - multiple myeloma } \\
\text { - myeloproliferative diseases } \\
\text { - halogenic and autologous transplant } \\
\text { - post-transplant immunosuppressive } \\
\text { therapy } \\
\text { - Evaluation of "donor versus recipient" } \\
\text { chimerism after bone marrow transplant } \\
\text { as a possibility of modulating post- } \\
\text { transplant immunosuppressive therapy } \\
\text { - Administration of high-dose } \\
\text { chemotherapy and conditioning } \\
\text { regimens } \\
\text { - Knowing the indications for transplant } \\
\text { for different pathologies } \\
\text { - Knowing the methods of HLA typification } \\
\text { methods } \\
\text { - Knowing how to manage the modalities } \\
\text { of infusion of peripheral/bone marrow } \\
\text { stem cells }\end{array}$ \\
\hline
\end{tabular}

\section{Myelodysplastic syndromes}

\begin{tabular}{|c|c|c|c|}
\hline Basic professionalism & Optimal professionalism & Excellent professionalism & Distinctive professionalism \\
\hline $\begin{array}{l}\text { Know how to identify Myelodysplastic } \\
\text { syndromes (MDS), their epidemiology, } \\
\text { and primitive and secondary forms }\end{array}$ & $\begin{array}{l}\text { - Knowing how to identify "isolated" } \\
\text { anaemia of MDS, its characteristics, } \\
\text { excluding possible secondary causes }\end{array}$ & $\begin{array}{l}\text { - Knowing how to carry out bone marrow } \\
\text { needle aspiration } \\
\text { - Knowing how to quantify the percentage } \\
\text { of blastic marrow cells }\end{array}$ & $\begin{array}{l}\text { - Knowing how to select patients who are } \\
\text { candidates for allogeneic bone marrow } \\
\text { transplant }\end{array}$ \\
\hline
\end{tabular}


- Knowing the modalities of presentation of a Myelodysplastic syndrome

- Knowing the indications for transfusional support (transfusion of erythrocytes and platelets)

- Knowing the mechanism of action of recombinant erythropoietin ( $r$-HU EPO) and therapeutic protocol (of attack and maintenance)

- Know the indications and limits of the use of G-CSF and GM-CSF growth factors
- Knowing how to identify "isolated" platelet disorder of MDS, its characteristics, excluding possible secondary causes

- Knowing how to diagnose Myelodysplastic syndromes on the basis of the diagnostic criteria of the Working Conference of

Vienna on MDS:

1) "indispensible" criteria

a) prolonged mono-or plurilinear cytopenia ( ${ }^{3} 6$ mos)

b) exclusion of other causes

2) "decisive" criteria

a) mono-or plurilinear morphological dysplasia (evaluation on aspirated bone marrow) in at least $10 \%$ of cells $\left(^{3} 15 \%\right.$ for ring-shaped sideroblasts

b) specific cytogenic anomalies - Knowing how to identify "isolated" leucopoenia of MDS (Myelodysplastic syndrome), its characteristics, excluding possible secondary causes

- Knowing how to evaluate the entity of martial excess with direct and indirect methods
- Knowing the "5q syndrome"

- Knowing the modality of iron chelation with deferoxamine (DFO), deferipron (L1), deferasirox and the therapeutic objectives on the basis of ferritin values
- Know how to evaluate the morphologica anomalies in bone marrow preparations which are characteristic of

diseritropoiesis (megaloblastosis, excess of E1-E2 precursors, nuclear

fragmentations, internuclear bridges, chromatinic irregularities, cytoplasmatic vacuoles, ring-shaped sideroblasts) disgranulopoiesis (alterations of nuclear lobulatin, absence of granules in the cytoplasm, Pelger pseudoanomaly and dismegacariocytopoiesis (presence of micromegakaryocytes, small binucleate megakaryocytes, single non-lobate nucleus or multinuclearity

- Knowing how to carry out a bone biopsy

- Knowing the prognostic IPSS system (International Prognostic Scoring System) which, on the basis of the percentage of blastic marrow cells, the karyotypical characteristics and the number of peripheral cytopenia, attributes a risk score for each patient, with the identification of 4 principal classes (low risk, intermediate-1, intermediate-2 and high)

- Knowing how to interpret the cytogenic study carried out on medullary blood, with evaluation of the risk classes:

a) favourable, b) intermediate

c) unfavourable

- Knowing the "WHO classification-based Prognostic Scoring System" (WPSS), which takes into account, the WHO classification, of the cytogenetics according to IPSS and transfusional requirements with the identification of 5 risk subgroups: very low, low, intermediate, high, very high

- Knowing lenalidomide and its appropriate indications for MDS and possible collateral effects

- Know azacitidine and methylating drugs, their appropriate indications for MDS and possible collateral effects 


\begin{tabular}{|c|c|c|c|}
\hline \multicolumn{4}{|l|}{ Venous thromboembolism } \\
\hline Basic professionalism & Optimal professionalism & Excellent professionalism & Distinctive professionalism \\
\hline 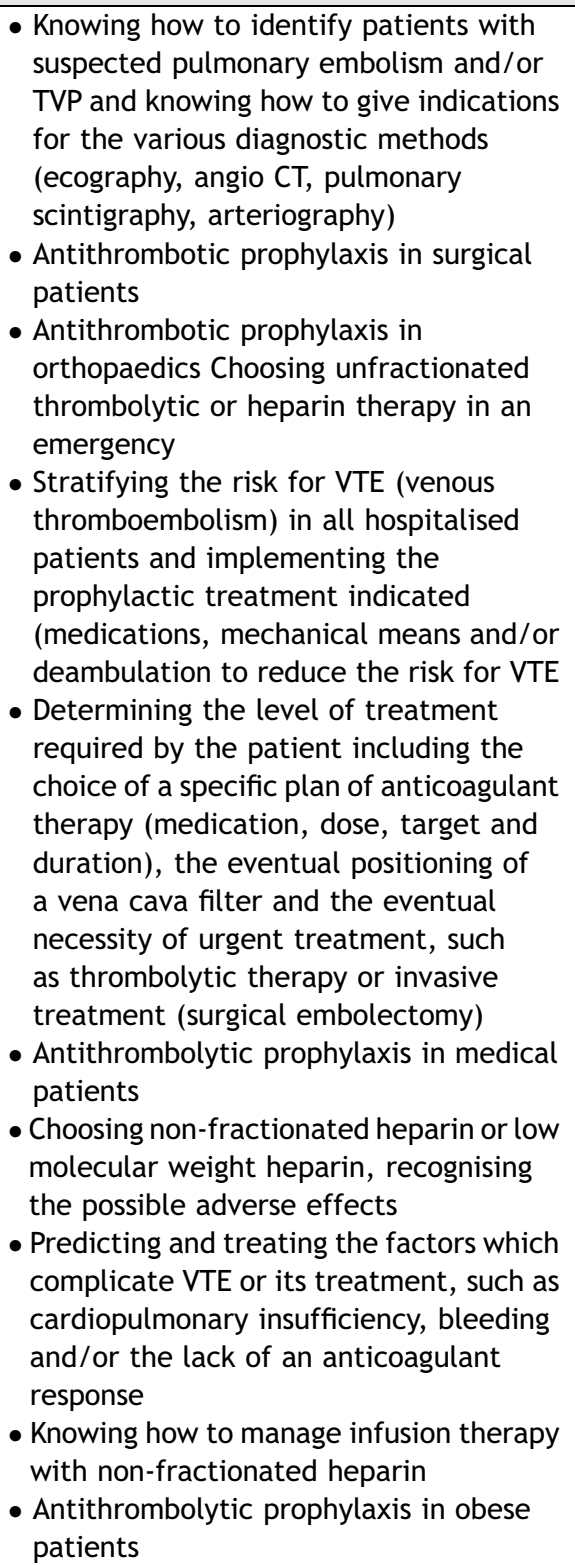 & $\begin{array}{l}\text { - Implement and manage fast circuits } \\
\text { ("fast track") for rapid access of the } \\
\text { patient to ultrasonography for the } \\
\text { diagnosis of venous thromboembolism } \\
\text { - Antithrombotic prophylaxis in } \\
\text { neurosurgery } \\
\text { - Antithrombotic prophylaxis in pregnancy } \\
\text { - Antithrombotic prophylaxis in fragile } \\
\text { elderly people, long-term care and in } \\
\text { oncological patients }\end{array}$ & $\begin{array}{l}\text { - Manage the follow-up of oral } \\
\text { anticoagulant therapy-OAT-over time } \\
\text { - Know how to choose patients who are } \\
\text { able to undergo positioning of a vena } \\
\text { cava filter }\end{array}$ & $\begin{array}{l}\text { - Manage the activity of venous ecography } \\
\text { for VTE Manage the screening laboratory } \\
\text { for VTE }\end{array}$ \\
\hline
\end{tabular}


- Knowing how to manage the check-up and therapy of platelet disorders from heparin (HIT-heparin-induced

thrombocytopenia)

- Choosing therapy with fondaparinux

- Antithrombolytic prophylaxis in renal

insufficiency

- Choosing therapy with dicoumarol in the patients who are unsuitable candidates for OAT

- Recognising platelet disorders from

heparin (HIT)

- Knowing how to correctly begin and

manage the first phases of OAT and be able to choose alternative protocols in the case of absolute contraindication to anticoagulant therapy

- Indicating the check-up and follow-up

modalities

- Indicating the modalities for follow-up, check-up and know how to furnish the patient with all the information

necessary to prevent risk for interaction of the OAT with food and medication.

- Knowing how to furnish indications for prevention

- Knowing how to advise the patient on the behaviour to follow in cases of bleeding or small surgical interventions

- Knowing how to carry out correct

diagnostic/prognostic stratification of a pulmonary embolism and select, on the basis of this, the most appropriate therapy 


\begin{tabular}{|c|c|c|c|}
\hline \multicolumn{4}{|l|}{ Diabetes mellitus } \\
\hline Basic professionalism & Optimal professionalism & Excellent professionalism & Distinctive professionalism \\
\hline $\begin{array}{l}\text { - Classifying the diabetes (DM) and } \\
\text { explaining the physiopathological } \\
\text { process which leads to hyperglycaemia, } \\
\text { diabetic ketoacidosis (DKA) and non- } \\
\text { ketotic hyperosmolarity (HHS) } \\
\text { - Knowing the diagnostic criteria of } \\
\text { diabetes, the classification and the } \\
\text { "pre-diabetic" form } \\
\text { - Knowing how to diagnose and treat } \\
\text { diabetes ketoacidosis (DKA) and non- } \\
\text { ketotic hyperosmolarity (HHS) } \\
\text { - Carrying out a complete anamnesis with } \\
\text { research of symptoms suggestive of an } \\
\text { acute co-pathology which can influence } \\
\text { glycaemic control, outpatient check-up } \\
\text { of glycaemia, compliance with the } \\
\text { therapy and social influences which can } \\
\text { influence glycaemic control } \\
\text { - Knowing how to evaluate the factors } \\
\text { which influence the onset and control } \\
\text { of diabetes } \\
\text { - Carrying out an objective exam able to } \\
\text { identify the precipitating causes of } \\
\text { hyperglycaemia, DKA and HHS } \\
\text { - Knowing how to evaluate the diagnostic } \\
\text { and prognostic significance of } \\
\text { hyperglycaemia when patient is } \\
\text { admitted to hospital } \\
\text { - Knowing how to manage infusion insulin } \\
\text { therapy in critical patients } \\
\text { - Identifying the glycaemic objective in } \\
\text { the hospital patient and the rationale for } \\
\text { strict control of glycaemia on morbidity } \\
\text { and mortality } \\
\text { - Facilitating the discharge plan for the } \\
\text { hospital patient } \\
\text { - Explaining the mechanism of action, } \\
\text { indications and contraindications of the } \\
\text { medications used for diabetes }\end{array}$ & $\begin{array}{l}\text { - Screening of sensory-motor } \\
\text { multineuropathy (Diabetic Neuropathy } \\
\text { Index-DNI) } \\
\text { - Ability to prescribe diagnostic- } \\
\text { therapeutic protocols for the diabetic } \\
\text { patient } \\
\text { - Carrying out and interpreting tests for } \\
\text { vegetative neuropathy } \\
\text { - Facilitating the discharge plan of the } \\
\text { hospital patient } \\
\text { - Utilising, from the moment of admission, } \\
\text { a multidisciplinary approach which can } \\
\text { include a nurse, dietician, anti-diabetic } \\
\text { centre and social services } \\
\text { - Explaining the objectives of discharge } \\
\text { and passage to safe treatment }\end{array}$ & $\begin{array}{l}\text { - Knowing how to carry out screening, } \\
\text { gestational diabetic diagnosis and } \\
\text { management of diabetes in pregnancy } \\
\text { - Organising, coordinating or participating } \\
\text { in the development of guidelines and } \\
\text { protocols for the optimisation of } \\
\text { glycaemic control in hospital patients } \\
\text { in various situations (patients with an } \\
\text { ordinary hospital stay, and surgical } \\
\text { and critical patients) } \\
\text { - Organising, coordinating and } \\
\text { participating in the development of } \\
\text { guidelines and protocols for } \\
\text { standardisation of the evaluation and } \\
\text { treatment of DKA and HHS } \\
\text { - Organising, coordinating or participating } \\
\text { in the development of guidelines and } \\
\text { protocols to develop the quality and } \\
\text { efficacy of diabetes management with } \\
\text { a multidisciplinary approach }\end{array}$ & $\begin{array}{l}\text { - Knowing how to carry out examination of } \\
\text { the ocular fundus with recognition of } \\
\text { background or advanced retinopathy } \\
\text { - Participating in a multidisciplinary team } \\
\text { expert in treatment for diabetic foot }\end{array}$ \\
\hline
\end{tabular}


- Knowing the different types of currently used insulin, human regulatory insulin and analogous rapid action insulin, modalities of use, pharmacological

characteristics (time of onset of action, maximum effect and duration of action)

- Documenting a therapeutic plan and discharge instructions interacting with the physician responsible for the outpatient follow-up and eventual documentation with CAD (coronary artery disease)

- Being able to choose quickly when to undertake insulin therapy in type 2 diabetic patients

- Knowing how to manage water content and the electrolytic alterations caused by DKA and HHS

- Regulating the pharmacological therapy in order to reach optimal glycaemic control, minimising collateral effects

- Recognising and treating hypoglycaemia - Recognising the indications for evaluation by a specialist

- Communicating with patients and family members to explain the history and prognosis of DM, possible long-term complications, prevention strategies, treatment objectives, adverse effects, diet, discharge plan, importance of glycaemic control and treatment of CV (cardiovascular) risk factors

\begin{tabular}{|c|c|c|c|}
\hline \multicolumn{4}{|c|}{$\begin{array}{l}\text { Management of patients with peripheral arteriopathy of the lower limbs (PAD = peripheral arteriopathy } \\
\text { disease) }\end{array}$} \\
\hline Basic professionalism & Optimal professionalism & Excellent professionalism & Distinctive professionalism \\
\hline $\begin{array}{l}\text { - Identifying patients at risk for PAD } \\
\text { - Carrying out an objective exam with } \\
\text { complete evaluation of peripheral pulse } \\
\text { and eventual vascular murmurs } \\
\text { - Knowing the natural history of the } \\
\text { disease and its evolution } \\
\text { - Knowing the stratification of PAD } \\
\text { according to Fontaine }\end{array}$ & $\begin{array}{l}\text { - Knowing the degrees and categories } \\
\text { of Rutherford for staging the illness } \\
\text { - Carrying out an } \mathrm{ABI} \text { (Ankle brachial } \\
\text { (pressure) index) index } \\
\text { - Knowing and applying the Wagner and } \\
\text { Texas University classifications for the } \\
\text { stratification of vascular skin ulcers } \\
\text { - Evaluating the results of the } \mathrm{ABI} \text { index }\end{array}$ & $\begin{array}{l}\text { - Identifying patients who are candidates } \\
\text { for possible endovascular treatment }\end{array}$ & $\begin{array}{l}\text { - Carrying out transcutaneous ossimetry } \\
\text { - Carrying out AAll arterial } \\
\text { echocolourDoppler } \\
\text { - Carrying out a detailed training program } \\
\text { for physical exercise (PAD AAll } \\
\text { rehabilitation) }\end{array}$ \\
\hline
\end{tabular}


- Evaluating the risk factors which can cause AAll (arti inferiori) critical ischemia

- Evaluating the results of angio CT

- Recognising acute ischemia of the

inferior limbs

- Recognising critical chronic ischemia

of the lower limbs

- Early recognition of acute ischemia of

the inferior limbs

- Sending the patient to a specialist rapidly

to evaluate carrying out

revascularisation, thrombectomy,

thrombolysis, etc.

- Carrying out a differential diagnosis

between the possible causes of trophic ulcers to the AAll

- Evaluating the comorbidities

(prevalently cardio-vascular) and the priorities correlated to them, identifying the patients at risk for CIN
- Knowing how to evaluate the results of arteriography

- Evaluating the results of angio CT

- Evaluating the results of angio MR

- Early recognition of critical chronic ischemia of the lower limbs

- Carrying out prostanoid/endoprost therapy

- Identifying patients who are candidates for possible revascularisation treatment

- Knowing how to evaluate global

operative risk

\begin{tabular}{|c|c|c|c|}
\hline \multicolumn{4}{|c|}{ Management of patients with acute renal insufficiency - ARI } \\
\hline Basic professionalism & Optimal professionalism & Excellent professionalism & Distinctive professionalism \\
\hline $\begin{array}{l}\text { - Defining the clinical significance of } \\
\text { prerenal, intrinsic and postrenal ARI, } \\
\text { identifying, by means of a complete } \\
\text { anamnesis (clinico-pharmacological), } \\
\text { the factors which may have precipitated } \\
\text { the ARI } \\
\text { - Knowing the signs and symptoms of } \\
\text { prerenal, intrinsic and postrenal ARI } \\
\text { - Carrying out an objective examination to } \\
\text { determine eventual water retention and } \\
\text { identify eventual comorbidities causing } \\
\text { ARI } \\
\text { - Knowing the causes of prerenal, intrinsic } \\
\text { and postrenal ARI } \\
\text { - Knowing how to evaluate the diagnostic } \\
\text { examinations and interpretations useful } \\
\text { for studying ARI (urine, urinary } \\
\text { sediment, protein urinary excretion, } \\
\text { serologic and renal imaging evaluations) }\end{array}$ & $\begin{array}{l}\text { - Knowing how to evaluate the RFI (Renal } \\
\text { Failure Index) on the basis of data of } \\
\text { urinary sodium in } \mathrm{m} / \mathrm{Eq} / \mathrm{L} \text {, urinary } \\
\text { creatinine in } \mathrm{mg} / \mathrm{dL} \text { and creatinemia } \\
\text { in } \mathrm{mg} / \mathrm{dL} \\
\text { - Prescribing an appropriate nutritional } \\
\text { plan and coordinating proper metabolic } \\
\text { intervention } \\
\text { - Recognising when to consult a } \\
\text { nephrologist and/or urologist } \\
\text { - Monitoring water and electrolytic } \\
\text { equilibrium } \\
\text { - Starting prevention measures which } \\
\text { include modifications in diet and } \\
\text { posological adjustment of the } \\
\text { medications used for the } \\
\text { comorbidities } \\
\text { - Adjusting the dose of medication to } \\
\text { the and the velocity of excretion }\end{array}$ & $\begin{array}{l}\text { - Program and manage a multidisciplinary } \\
\text { approach which can include a nurse, } \\
\text { dietician, pharmacist to identify patients } \\
\text { who can benefit from early } \\
\text { haemodialytic treatment } \\
\text { - Communicate with patients and family } \\
\text { members to explain the diagnostic } \\
\text { procedures, their use and the potential } \\
\text { collateral effects of the medications } \\
\text { used } \\
\text { Know how to identify and manage } \\
\text { patients at risk for nephrogenic systemic } \\
\text { fibrosis (NSF) }\end{array}$ & $\begin{array}{l}\text { - Carry out peritoneal dialysis } \\
\text { - Provide for the preparation of vascular } \\
\text { access for haemodialysis }\end{array}$ \\
\hline
\end{tabular}


- Communicating with patients and family members to explain the objectives of the treatment and the therapeutic measures to be continued at home

- Indicating which clinical, laboratory and imaging exams to request for a correct picture of ARI

- Communicating with patients and family members to explain the diagnostic procedures, their use and the potential collateral effects of the medications used

- Knowing the electrolytic imbalances which occur in the course of ARI and knowing how to correct them

- Calculating the correct glomerular filtrate for the correct adjustment of the posologies of the medications to be administered

- Identifying the patients at risk for ARI and instituting the correct measures

to avoid it

- Knowing how to identify and manage patients at risk for nephropathy using contrast-induced nephropathy, also on the basis of the CIN (contrast-induced nephropathy) risk score

- Identifying and treating the factors which can complicate the course of ARI,

including arterial pressure and infections - Utilising the recommendations of EBM, and the protocols and risk stratification for the treatment of ARI

- Knowing the indications and contraindications of suitable

medications for the treatment of ARI

- Knowing the indications for

haemodialytic treatment
- Knowing which methods of iodate and non-iodate contrast mediums to avoid; recognising and avoiding nephrotoxic agents and, if necessary, knowing how to monitor renal function and the dosage of useful medications 


\begin{tabular}{|c|c|c|c|}
\hline \multicolumn{4}{|c|}{ Management of patients with chronic renal insufficiency - CRI } \\
\hline Basic professionalism & Optimal professionalism & Excellent professionalism & Distinctive professionalism \\
\hline $\begin{array}{l}\text { - Rapid recognition of the presence of CRI; } \\
\text { calculating the clearance of creatinine } \\
\text { by means of the most current formula } \\
\text { (Cockfort.Gault, MDRD (modification of } \\
\text { diet in renal disease), CKD-Epi (chronic } \\
\text { kidney disease epidemiology } \\
\text { collaboration)) to estimate the FG Vol } \\
\text { (fasting glucose volume), but also to } \\
\text { recognise the limits of the formulas } \\
\text { utilised } \\
\text { - Knowing the modalities for evaluating } \\
\text { proteinuria } \\
\text { pystematically searching for CRI in } \\
\text { patients at risk: type } 1 \text { or } 2 \text { diabetes } \\
\text { mellitus, arterial hypertension, CV } \\
\text { illnesses (ischemic cardiopathy, heart } \\
\text { failure, peripheral arteriopathy,cerebro- } \\
\text { vascular disease), structural illness of } \\
\text { the urinary tract (nephrolythiasis, } \\
\text { prostatic hypertrophy, etc.), systemic } \\
\text { diseases with possible renal involvement } \\
\text { (e.g. systemic lupus erythematous (SLE), } \\
\text { multiple myeloma), family-inherited } \\
\text { history of renal illness } \\
\text { - Evaluating the most appropriate } \\
\text { antihypertensive medications for CRI } \\
\text { for drug dependent nephrotoxic damage } \\
\text { treatment with ACE (angiotensin } \\
\text { comverting enzyme) inhibitors } \\
\text { intervals of drug administration, } \\
\text { checking for possible adverse reactions) } \\
\text { in relation to renal function (NSAIDS } \\
\text { (non-steroid anti-inflammatory drugs), } \\
\text { antibiotics, heparin, etc.) }\end{array}$ & $\begin{array}{l}\text { - Knowing the stratification of the IRC } \\
\text { according to the U.S. National Kidney } \\
\text { Foundation Kidney Disease Outcomes } \\
\text { Quality initiative (NKF-KDOQI) } \\
\text { - Using the ACR ratio (albumin-creatinine } \\
\text { ratio) correctly to identify proteinuria } \\
\text { - Autonomously proposing the diagnostic } \\
\text { protocol for diagnosing ischemic } \\
\text { nephropathy } \\
\text { - Knowing the pharmacokinetics of the } \\
\text { principal medications for CRI } \\
\text { - Knowing how to identify and manage } \\
\text { patients at risk for nephrogenic systemic } \\
\text { fibrosis (NSF) }\end{array}$ & $\begin{array}{l}\text { - Evaluating urinary sediment } \\
\text { - Evaluating the presence of a possible } \\
\text { stenosis of the renal artery using } \\
\text { diagnostic ecography and } \\
\text { echocolourdoppler } \\
\text { - Knowing how to predict possible recovery } \\
\text { of renal function in the presence of } \\
\text { ischemic nephropathy } \\
\text { - Know the limits and indications for } \\
\text { revascularisation } \\
\text { - Predicting possible recovery of renal } \\
\text { function in the presence of CIN } \\
\text { - Evaluating asymptomatic urinary } \\
\text { alterations } \\
\text { - Evaluating and treating alterations of the } \\
\text { calcium and phosphorous metabolism } \\
\text { in patients with CRI } \\
\text { - Managing renal osteodystrophy in adults } \\
\text { with CRI }\end{array}$ & $\begin{array}{l}\text { - Carrying out peritoneal dialysis } \\
\text { - Evaluating asymmetry of renal volume } \\
\text { using diagnostic ecography and } \\
\text { echocolourdoppler } \\
\text { - Providing for the preparation of vascular } \\
\text { access for haemodialysis } \\
\text { - Evaluating the presence of a possible } \\
\text { stenosis of the renal artery using } \\
\text { diagnostic ecography and } \\
\text { echocolourdoppler } \\
\text { - Managing haemodialysis in an emergency } \\
\text { situation and/or in za critical area }\end{array}$ \\
\hline
\end{tabular}


(eritropoietine)

- Managing multitherapy and the possible pharmacological interactions regarding

a possible nephrotoxic risk

- Carrying out martial therapy (evaluation of need for iron, of the martial state, absolute and/or functional lack of iron, possible excess, evaluation of reserves, supplementation modalities, etc.)

- Suspecting the presence of

arterioschlerotic ischemic nephropathy

- Identifying patients with suspected

secondary arterial hypertension

- Knowing how to identify and manage

patients at risk for nephropathy by

contrast-induced nephropathy, also on

the basis of the CIN risk score

- Utilising statins during the course of CRI

- Know the prevention protocols of CIN

- Selecting patients with CRI to go to a

nephrologist for evaluation and

specialistic treatment

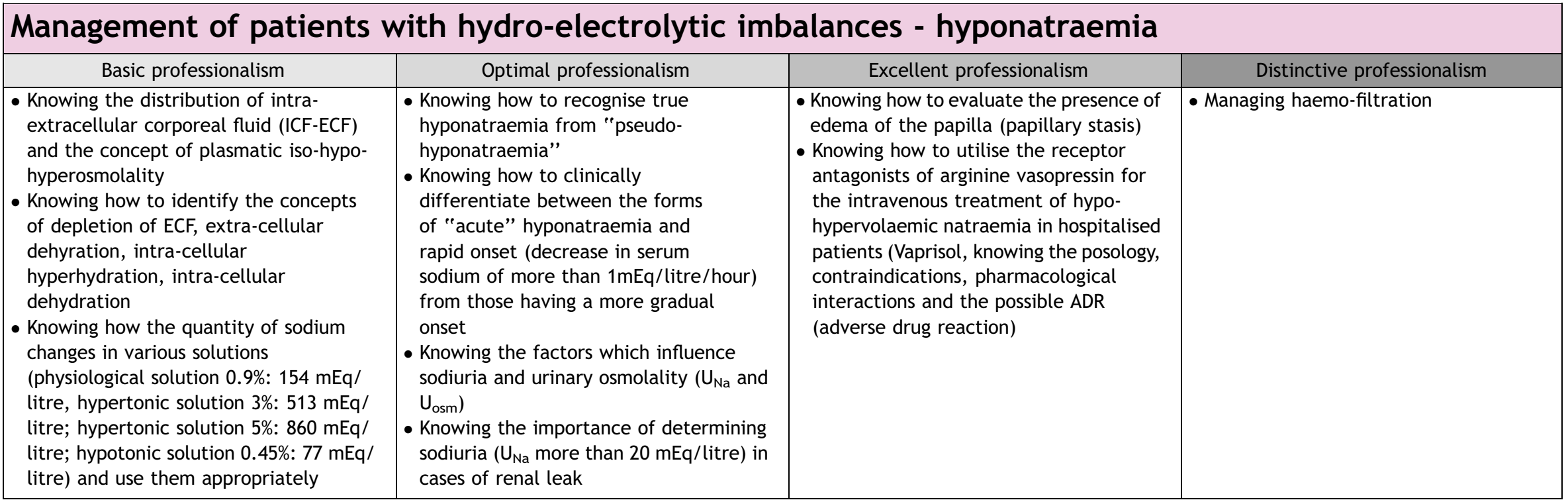


- Knowing how to identify the concept of "free water"

- Knowing how to identify the concept of "osmolarity" and apply the formulas to calculate plasmatic osmolarity

- Know how to identify the concept of

"effective blood volume" and knowing the physiopathology of the modifications of blood volume

- Knowing the physiopathology of osmoregulation and regulation of circulating volume

- Knowing how to identify hypotonic-

isovolaemic hyponatraemia

- Knowing how to distinguish between real lack of total sodium from a condition of water excess with normal total sodium from a situation of sodium excess with a greater excess of water

- Knowing how to describe the possible causes of ECF depletion (renal and extrarenal loss)

- Knowing how to identify hyponatraemia

- Knowing how to differentiate the various forms of hyponatraemia:

1) hypertonic

2) isotonic

3) hypotonic:
3a. hypervolaemic
3b. isovolaemic

3c. hypovolaemic

- Knowing the possible causes of

hyponatraemia

- Knowing the modalities of clinical

presentation of hyponatraemia on the basis of the values of serum sodium

$(\mathrm{mEq} / \mathrm{l})$

- Knowing the clinical signs of water

intoxication

- Knowing the clinical signs of dehydration

- Knowing the causes of inappropriate

secretion of ADH (antidiuretic hormone)

(SIADH-syndrome of inappropriate

antidiuretic hormone) and the possible

therapeutic options
- Knowing how to calculate the quantity of sodium to infuse, using Adrogué's

formula

- Knowing how to differentiate rapid onset hyponatraemia from the "chronic" forms

- Knowing how to set up therapy for

hypotonic-hypervolaemic

hyponatraemia

- Knowing how to calculate the quantity of sodium multiplying the plasmatic sodium deficit $(\mathrm{mEq} / \mathrm{l})$ by the total corporeal water (litres)

- Knowing how to evaluate the time of infusion and the velocity of correction

- Know how to formulate therapy for

hypotonic-hypervolaemic

hyponatraemia

- Knowing how to choose a suitable type of solution (hypertonic saline 3\%) in the presence of convulsions or other acute neurological symptoms

- Knowing how to recognise the picture of pontine myelinolysis following errors in the correction of sera sodium

- Know how to manage hyponatraemia AR

- Know how to manage hyponatraemia in CRI 


\section{Management of patients with hydro-electrolytic imbalances - hypernatraemia}

\begin{tabular}{|c|c|c|c|}
\hline Basic professionalism & Optimal professionalism & Excellent professionalism & Distinctive professionalism \\
\hline $\begin{array}{l}\text { - Knowing how to identify hypernatraemia } \\
\text { - Knowing how to recognise and manage } \\
\text { the comorbidites/causes underlying } \\
\text { hypernatraemia } \\
\text { - Knowing how to manage the therapy for } \\
\text { hypernatraemia in case of depletion } \\
\text { of the effective circulating volume } \\
\text { - Knowing how to identify the concepts } \\
\text { of hypertonic osmolarity and cellular } \\
\text { dehydration } \\
\text { - Knowing how to describe the causes } \\
\text { of hypernatraemia from water loss } \\
\text { - Knowing how to differentiate } \\
\text { hyperosmolar coma from other types } \\
\text { of coma } \\
\text { - Knowing how to describe the causes of } \\
\text { hypernatraemia from hypotonic sodium } \\
\text { loss (ECF depletion) } \\
\text { - Knowing the formulas to manage } \\
\text { hypernatraemia } \\
\text { - Knowing how to describe the causes of } \\
\text { hypernatraemia from hypotonic sodium } \\
\text { and potassium loss } \\
\text { - Knowing how to describe the causes of } \\
\text { hypernatraemia from an excess of } \\
\text { sodium infusion } \\
\text { - Knowing the characteristics of the } \\
\text { solutions to infuse in case of } \\
\text { hypernatraemia } \\
\text { - Knowing how to describe the } \\
\text { characteristics of patients at greatest } \\
\text { risk for hypernatraemia } \\
\text { of hypernatraemia } \\
\text { emergency }\end{array}$ & $\begin{array}{l}\text { - Knowing the consequences and the } \\
\text { adaptive responses to hypernatraemia on } \\
\text { the CNS } \\
\text { - Knowing how to manage correction of } \\
\text { water deficit } \\
\text { - Knowing how to manage therapy for } \\
\text { hypernatraemia in case of depletion of } \\
\text { the effective circulating volume } \\
\text { - Knowing the formulas to correct water } \\
\text { deficit } \\
\text { - Knowing how to differentiate } \\
\text { hypernatraemia from renal loss from that } \\
\text { having extrarenal causes on the basis of } \\
\mathrm{U}_{\mathrm{Na}} \text { and } \mathrm{U}_{\mathrm{osm}}\end{array}$ & $\begin{array}{l}\text { - Knowing how to manage therapy for } \\
\text { hypernatraemia in the presence of } \\
\text { normal effective circulating volume } \\
\text { - Knowing how to manage therapy for } \\
\text { hypernatraemia in the presence of } \\
\text { elevated effective circulating volume }\end{array}$ & \\
\hline
\end{tabular}


Management of patients with hydro-electrolytic imbalances - hypokalaemia

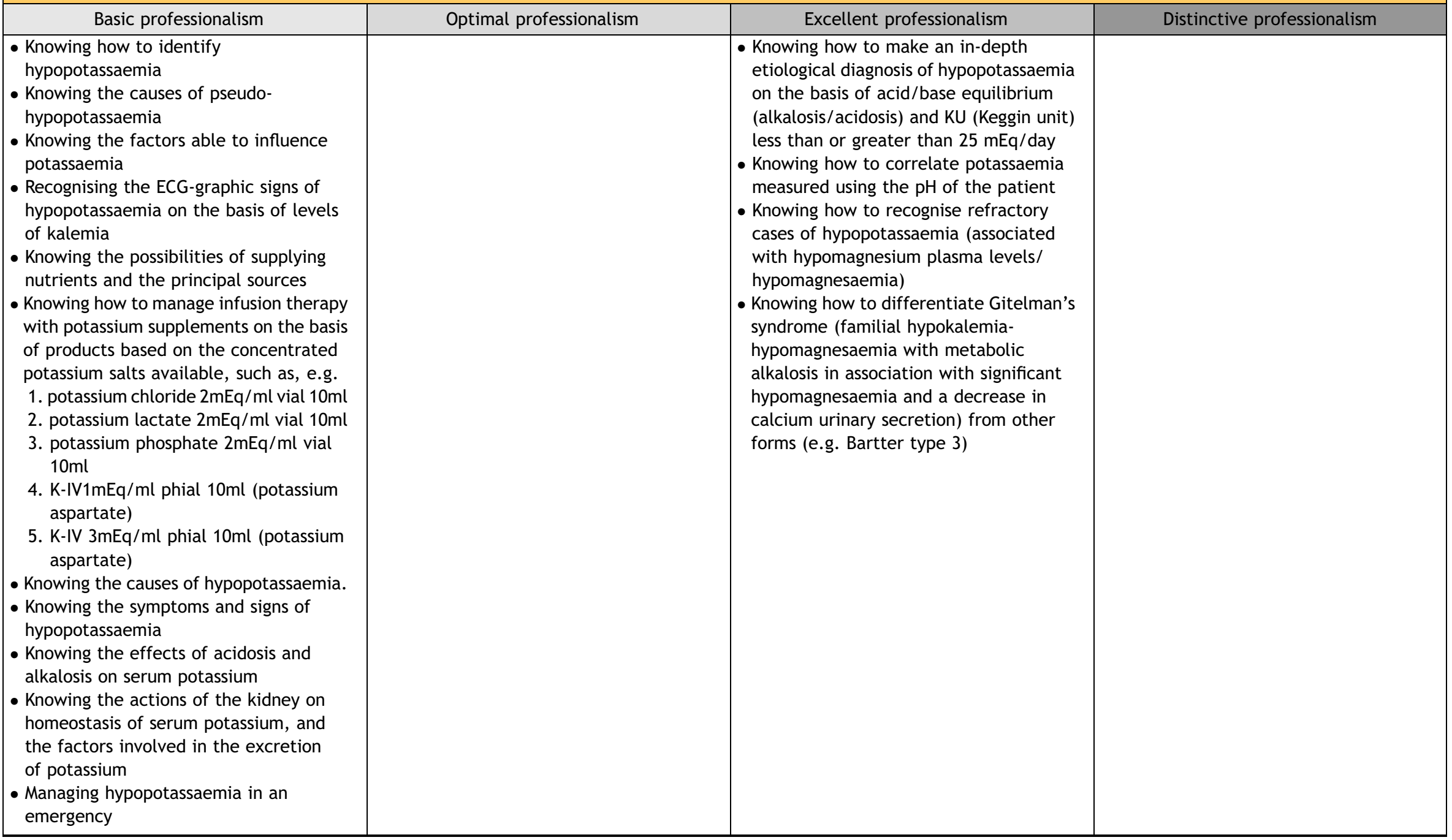




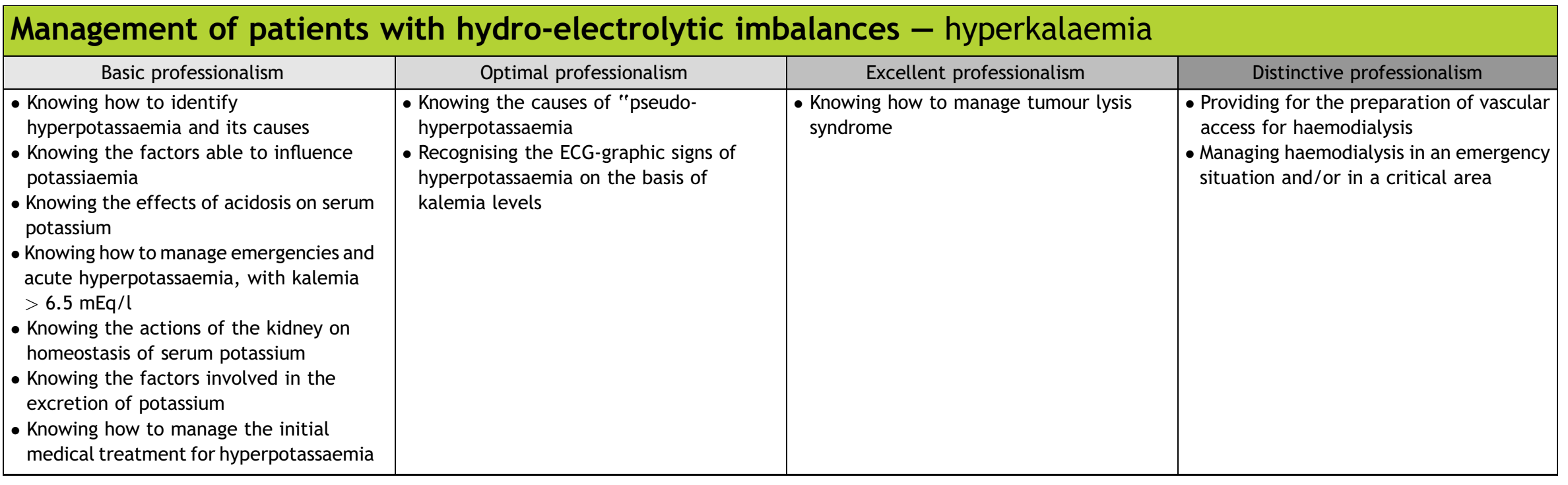

\begin{tabular}{|c|c|c|c|}
\hline Basic professionalism & Optimal professionalism & Excellent professionalism & Distinctive professionalism \\
\hline $\begin{array}{l}\text { - Knowing the physiopathology of } \\
\text { magnesium, its balance (absorption, } \\
\text { excretion), daily need (RDNR) and its } \\
\text { concentration in nutrients and its } \\
\text { principal sources } \\
\text { - Knowing how to identify } \\
\text { hypomagnesaemia and its causes } \\
\text { - Knowing how to identify the iatrogenic } \\
\text { causes of increased urinary loss of } \mathrm{Mg} \\
\text { - Knowing the symptoms and signs of } \\
\text { hypomagnesaemia } \\
\text { - Knowing how to manage emergencies } \\
\text { with magnesaemia }<1.2 \text { md/dl: tetany, } \\
\text { malignant arrythymias, convulsions }\end{array}$ & - Knowing how to utilise infusions of $\mathrm{MgSO} 4$ & $\begin{array}{l}- \text { Knowing how to diagnose Gitelman's } \\
\text { syndrome (see above: hypopotassemia) }\end{array}$ & \\
\hline
\end{tabular}




\section{Management of patients with hydro-electrolytic imbalances - hypermagnesaemia}

\begin{tabular}{|c|c|c|c|}
\hline Basic professionalism & Optimal professionalism & Excellent professionalism & Distinctive professionalism \\
\hline $\begin{array}{l}\text { Knowing the physiopathology of } \\
\text { magnesium, its balance (absorption, } \\
\text { excretion), daily need (RDNR- } \\
\text { recommended daily nutritional } \\
\text { requirements) and its concentration } \\
\text { in nutrients and its principal sources } \\
\text { - Knowing how to identify } \\
\text { hypermagnesaemia and its causes } \\
\text { - Knowing the symptoms and signs of } \\
\text { hypermagnesaemia }\end{array}$ & $\begin{array}{l}\text { - Knowing how to diagnose Gitelman's } \\
\text { syndrome (see above: hypopotassemia } \\
\text { - Knowing how to utilise iv infusion of } \\
\text { calcium to antagonise respiratory } \\
\text { depression while waiting for } \\
\text { haemodialysis }\end{array}$ & $\begin{array}{l}\text { - Knowing how to manage therapy for } \\
\text { serious intoxication from } \mathrm{Mg} \text { with } \\
\text { circulatory and respiratory support }\end{array}$ & \\
\hline
\end{tabular}

\begin{tabular}{|c|c|c|c|}
\hline \multicolumn{4}{|c|}{ Management of patients with hydro-electrolytic imbalances - hypophosphoraemia } \\
\hline Basic professionalism & Optimal professionalism & Excellent professionalism & Distinctive professionalism \\
\hline $\begin{array}{l}\text { Knowing the physiopathology of } \\
\text { phosphorus, its balance (absorption, } \\
\text { excretion), daily need (RDNR) and its } \\
\text { concentration in nutrients and its } \\
\text { principal sources } \\
\text { - Knowing how to identify } \\
\text { hypophosphataemia and its causes } \\
\text { - Knowing the clinical manifestations and } \\
\text { consequences of hypophosphataemia on } \\
\text { the mitochrondrial metabolism, the } \\
\text { oxidative phosphorylation and the } \\
\text { dissociation of haemoglobin }\end{array}$ & $\begin{array}{l}\text { - Knowing how to manage the therapy } \\
\text { for acute hypophosphataemia } \\
\text { - Knowing how to manage the therapy } \\
\text { for chronic hypophosphataemia }\end{array}$ & & \\
\hline
\end{tabular}

\begin{tabular}{|c|c|c|c|}
\hline \multicolumn{4}{|c|}{ Management of patients with hydro-electrolytic imbalances - hyperphosphoraemia } \\
\hline Basic professionalism & Optimal professionalism & Excellent professionalism & Distinctive professionalism \\
\hline $\begin{array}{l}\text { - Knowing the physiopathology of } \\
\text { phosphorus, its balance (absorption, } \\
\text { excretion), the factors regulating } \\
\text { intestinal absorption, daily need (RDNR) } \\
\text { and its concentration in nutrients and } \\
\text { its principal sources } \\
\text { - Identifying hyperphosphataemia and } \\
\text { knowing its causes } \\
\text { - Differentiating the acute forms from } \\
\text { the chronic forms }\end{array}$ & $\begin{array}{l}\text { - Knowing the causes of "pseudo- } \\
\text { hyperphosphataemia" from haemolysis } \\
\text { - Knowing how to treat hypocalcaemic } \\
\text { tetanic crises from acute } \\
\text { hyperphosphataemia } \\
\text { - Knowing how to identify dietetic } \\
\text { restrictions and therapy with P chelating } \\
\text { agents }\end{array}$ & $\begin{array}{l}\text { - Identifying and calculating the product } \\
\text { of solubility between } \mathrm{Ca}+\text { and } \mathrm{P} \\
\text { - Knowing how to manage tumour lysis } \\
\text { syndrome }\end{array}$ & \\
\hline
\end{tabular}


- Knowing the clinical manifestations and consequences of hyperphosphataemia on the myocardium and the cardiac valves (arrythymias and valvulopathies),

vessels (digital gangrene), intestine,

kidney (worsening of interstitial damage and function)

\section{Management of patients with alterations of the acid/base equilibrium}

Basic professionalism

- Knowing how to identify acid, base,

buffer

- Indicating the possible causes of increase

in or loss of $\mathrm{H}^{+}$

- Identifying haematic $\mathrm{pH}$ and its normal

values, hydrogen ionic concentration

and its normal values, the concepts of

acidaemia and alkalaemia, the $\mathrm{CO}_{2} /$

$\mathrm{HCO}_{3}{ }^{-}$ratio, the concept of acidosis

and alkalosis

- Describing the consequences of

acidaemia $<7.38$ on the organism

- Describing the buffers (bicarbonates,

phosphates, protein, haemoglobin $(\mathrm{Hb})$ )

- Describing the consequences of

alkalaemia $>7.42$ on the organism

- Describing the normal process of

secretion of $\mathrm{CO}_{2}$ (ventilation, diffusion,

perfusion)

- Recognising the symptoms and clinical

signs of a state of acidosis

- Describing the role of the respiratory

system and the kidney in the acid-base

equilibrium

- Recognising the symptoms and clinical

signs of a state of alkalosis

- Identifying the concept of anionic gap

and its determinants (anions-cations)

- Identifying the concept of "expected

compensation" (or "predicted")

- Classifying acidosis and alkalosis on

the basis of $\mathrm{pH}, \mathrm{HCO}_{3}{ }^{-}, \mathrm{pCO}_{2}$ levels

- Describing the significance of

Henderson's equation and the

Henderson-Hasselbach variant

- Knowing how to calculate the "expected

compensation" (or "predicted")

- Knowing how to calculate the

bicarbonates necessary to obtain clinical compensation

- Knowing how to calculate the alkalisers

necessary to obtain clinical

compensation 
- Identifying the concept of compensated/

uncompensated acidosis and alkalosis

- Knowing the indications and

contraindications for the use of

bicarbonates

- Knowing the indications and

contraindications for the use of other

alkalisers

\begin{tabular}{|c|c|c|c|}
\hline \multicolumn{4}{|c|}{ Management of patients with alterations of the acid/base equilibrium - metabolic acidosis } \\
\hline Basic professionalism & Optimal professionalism & Excellent professionalism & Distinctive professionalism \\
\hline $\begin{array}{l}\text { - Knowing how to identify metabolic } \\
\text { acidosis } \\
\text { - Knowing the principal causes of } \\
\text { metabolic acidosis } \\
\text { - Knowing how to manage ketoacidotic } \\
\text { diabetic coma } \\
\text { - Knowing how to identify the concept of } \\
\text { lactic acidosis and lactacidaemia } \\
\text { - Knowing how to recognise mixed pictures }\end{array}$ & $\begin{array}{l}\text { - Knowing how to manage the principal } \\
\text { causes of metabolic acidosis, such as e.g. } \\
\text { - uremic acidosis from advanced CRI } \\
\text { - diabetic ketoacidosis } \\
\text { - lactic acidosis } \\
\text { - intoxication from methyl alcohol, } \\
\text { paraldehyde, ethylene, salicylate } \\
\text { - alcoholic ketoacidosis } \\
\text { - overdose of iron } \\
\text { - Knowing how to manage therapy with } \\
\text { sodium bicarbonate } \\
\text { - Knowing how to differentiate patients } \\
\text { who are candidates for conservative } \\
\text { therapy from those who require } \\
\text { intensive/nephrological/dialytic } \\
\text { intervention } \\
\text { - Knowing how to manage } \\
\text { hyperlactacidaemia and lactic acidosis }\end{array}$ & $\begin{array}{l}\text { - Knowing how to classify the forms of } \\
\text { metabolic acidosis with a normal } \\
\text { anionic gap } \\
\text { - light-moderate CRI } \\
\text { - gastrointestinal loss of HCO3 (acute } \\
\text { profuse diarrhoea) } \\
\text { - type } 1 \text { distal renal tubular acidosis } \\
\text { - type II proximal renal tubular acidosis } \\
\text { - dilutional acidosis } \\
\text { - treatment of diabetic distal renal } \\
\text { tubular acidosis } \\
\text { - Knowing the causes of } \\
\text { hyperlactacidaemia and lactic acidosis } \\
\text { according to Cohen and Woods }\end{array}$ & \\
\hline
\end{tabular}

\begin{tabular}{|l|l|l|l|}
\hline \multicolumn{1}{|c|}{ Management of patients with alterations of the acid/base equilibrium - respiratory acidosis } \\
\hline \multicolumn{1}{|c|}{ Basic professionalism } & \multicolumn{1}{|c|}{ Optimal professionalism } & \multicolumn{1}{c|}{ Excellent professionalism } & \multicolumn{1}{c|}{ Distinctive professionalism } \\
\hline $\begin{array}{l}\text { Knowing how to identify respiratory } \\
\text { acidosis }\end{array}$ & $\begin{array}{l}\text { Knowing how to differentiate the } \\
\text { patients who are candidates for non- } \\
\text { invasive therapy from those who require } \\
\text { intensive treatment }\end{array}$ & $\begin{array}{l}\text { Knowing how to carry out NIV } \\
\text { (non-invasive ventilation) }\end{array}$ & $\begin{array}{l}\bullet \text { Knowing how to apply an extra-glottic } \\
\text { devices }\end{array}$ \\
$\begin{array}{l}\text { patients who are candidates for non- } \\
\text { invasive therapy from those who require } \\
\text { intensive treatment }\end{array}$ & $\begin{array}{l}\text { Knowing how to apply the Kelly-Matthay } \\
\text { Scale to evaluate the neurological state } \\
\text { of patients with respiratory insufficiency }\end{array}$ & & \\
$\begin{array}{l}\text { Knowing the principal causes of } \\
\text { respiratory acidosis }\end{array}$ & & & \\
\hline
\end{tabular}




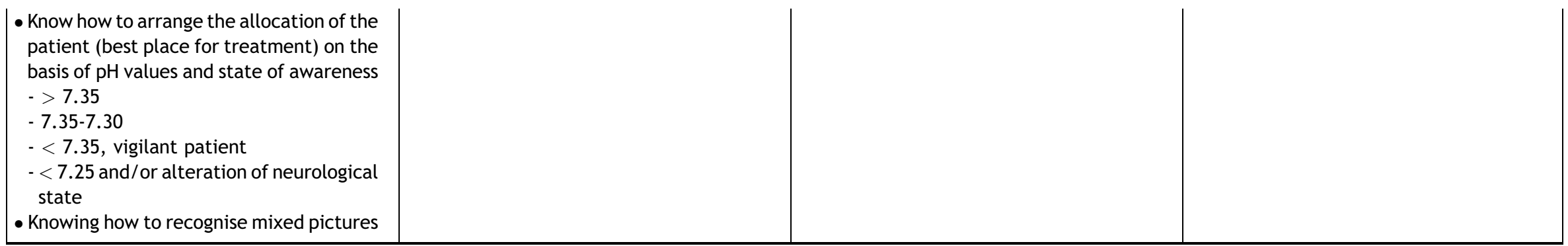

\begin{tabular}{|l|l|l|l|}
\hline \multicolumn{1}{|c|}{ Management of patients with alterations of the acid/base equilibrium - metabolic alkalosis } \\
\hline \multicolumn{1}{|c|}{ Basic professionalism } & Optimal professionalism & \multicolumn{1}{|c|}{ Excellent professionalism } & \\
\hline - Knowing how to identify the concept & & & \\
of metabolic alkalosis & & \\
- Knowing how to manage the therapy & & \\
(inhibiting acid loss, restoring & & \\
extracellular volume with NaCl & & \\
solutions, reintegrating & & \\
hypopotassaemia/hypokalemia & & \\
Knowing the principal causes of & & \\
metabolic alkalosis & & \\
- Knowing how to recognise mixed pictures & & \\
\hline
\end{tabular}

\begin{tabular}{|c|c|c|c|}
\hline \multicolumn{4}{|c|}{ Management of patients with alterations of the acid/base equilibrium - respiratory alkalosis } \\
\hline Basic professionalism & Optimal professionalism & Excellent professionalism & Distinctive professionalism \\
\hline $\begin{array}{l}\text { - Knowing how to identify respiratory } \\
\text { alkalosis } \\
\text { - Knowing the principal causes of } \\
\text { respiratory alkalosis }\end{array}$ & $\begin{array}{l}\text { - Knowing how to treat the underlying } \\
\text { causes } \\
\text { - Knowing how to manage re-breathing }\end{array}$ & & \\
\hline
\end{tabular}

\begin{tabular}{|c|c|c|c|}
\hline \multicolumn{4}{|c|}{ Management of hospital patients with malnutrition } \\
\hline Basic professionalism & Optimal professionalism & Excellent professionalism & Distinctive professionalism \\
\hline $\begin{array}{l}\text { - Knowing how to identify malnutrition, } \\
\text { undernutrition } \\
\text { - Knowing the consequences of fasting and } \\
\text { undernutrition } \\
\text { - Knowing how to carry out rapid selection } \\
\text { of patients at risk for malnutrition and } \\
\text { know the screening tests }\end{array}$ & $\begin{array}{l}\text { - Knowing how to differentiate decline/ } \\
\text { decay, kwashiorkor, lack of } \\
\text { micronutrients, PEM (protein energy } \\
\text { malnutrition) } \\
\text { - Know how to use screening tests: } \\
\text { - MUST (Malnutrition screening tool): } \\
\text { community }\end{array}$ & $\begin{array}{l}\text { - Knowing how to apply the Nutritional Risk } \\
\text { Index (NRI = (1.489 } \times \text { serum albumin } \\
(\mathrm{g} / \mathrm{L})+41.7 \times \text { (current weight/normal } \\
\text { weight) } \\
\text { - Knowing how to calculate the BEE (Basal } \\
\text { Energy Expenditure) with the Harris- } \\
\text { Benedict equation }\end{array}$ & $\begin{array}{l}\text { - Knowing how to carry out specific } \\
\text { functional tests: } \\
\text { - muscular function (dynamometry, etc.) } \\
\text { - respiratory muscular function } \\
\text { (spirometry, etc.) } \\
\text { - mood and mental function (mood score, } \\
\text { etc.) }\end{array}$ \\
\hline
\end{tabular}


- Knowing how to carry out a specific anamnesis

- Knowing how to calculate the BMI and evaluate the results (in excess and in deficit)

- Knowing how to recognise the clinical signs of malnutrition on the basis of the deficit of individual macro/

micronutrients/vitamins, etc.

- Knowing how to research and interpret laboratory data for the evaluation of malnutrition

- Knowing the underlying ethical aspects of the topic of artificial nutrition
- NRS (Nutritional Risk Screening): hospitalised patients

MNA (Mini Nutritional Assessment): elderly people

- Knowing how to carry out a 24h/7day

alimentary anamnesis

- Knowing how to calculate water

requirement

- Knowing how to classify dysphagia and give indications regarding type and modality of alimentation

- Knowing how to carry out the water swallow test ( 3 spoons and a glass) and evaluate the dysphagia according to levels of severity

- Knowing how to evaluate anthropometric

data for a clinical-prognostic judgment

- Planning a program of assistance

- Planning diet therapy on the basis of

the basic pathology

- Selecting the patients who require

artificial nutritional support

- Selecting the patients who are

candidates for alimentation with a

nasogastric probe

- Prescribing enteral artificial nutrition

- Selecting the patients who are

candidates for PEG (percutaneous

endoscopic gastrotomy)
- Knowing how to calculate and prescribe the daily caloric requirement subdivided by marcronutrients

- Knowing how to calculate and prescribe

the vitamin requirement

- Prescribing and managing PEG

- Knowing how to recognise the

pathological conditions requiring an increased caloric, water, proteic,

micronutrient (vitamin, oligoelement, electrolyte) requirement

- Knowing the indications of MCT (medium chain triglycerides) and branched

aminoacids

- Prscribe parenteral nutrition

- Manage the follow-up of patients on TEN-

TPN (total enteral nutrition-total parenteral nutrition)
- Knowing how to insert a CVC (centra venous catheter) for total parenteral nutrition

\begin{tabular}{|c|c|c|c|}
\hline \multicolumn{4}{|c|}{ Management of hospital patients with nodular pathologies of the thyroid } \\
\hline Basic professionalism & Optimal professionalism & Excellent professionalism & Distinctive professionalism \\
\hline $\begin{array}{l}\text { - Classify the problems from a diagnostic } \\
\text { point of view }\end{array}$ & $\begin{array}{l}\text { - Managing the problems together with } \\
\text { other specialists } \\
\text { - Knowing how to identify the most } \\
\text { suitable therapeutic solutions } \\
\text { - Knowing how to identify patients who } \\
\text { are candidates for surgery }\end{array}$ & $\begin{array}{l}\text { - Managing the diagnostic path } \\
\text { autonomously }\end{array}$ & $\begin{array}{l}\text { - Carrying out echo-ultrasonographic } \\
\text { investigations directly } \\
\text { - Carrying out echo-ultrasonographic } \\
\text { and bioptic investigations directly } \\
\text { - Carrying out some therapeutic } \\
\text { techniques, such as alcoholisation, } \\
\text { ablative therapy with laser or } \\
\text { thermofrequency }\end{array}$ \\
\hline
\end{tabular}




\begin{tabular}{|c|c|c|c|}
\hline \multicolumn{4}{|c|}{ Management of hospital patients with thyroid dysfunction } \\
\hline Basic professionalism & Optimal professionalism & Excellent professionalism & Distinctive professionalism \\
\hline $\begin{array}{l}\text { Knowing how to classify the problems } \\
\text { from a diagnostic point of view and } \\
\text { formulate standard therapy }\end{array}$ & $\begin{array}{l}\text { - Interpreting "ambiguous" laboratory } \\
\text { pictures }\end{array}$ & $\begin{array}{l}\text { - Formulating and managing unusual } \\
\text { treatments for particular situations } \\
\text { - Managing patients thyroidectomised } \\
\text { for thyroid neoplasias }\end{array}$ & - Managing Basedowian ophthalmopathy \\
\hline
\end{tabular}

\begin{tabular}{|c|c|c|c|}
\hline \multicolumn{4}{|c|}{ Management of hospital patients with hepatic cirrhosis } \\
\hline Basic professionalism & Optimal professionalism & Excellent professionalism & Distinctive professionalism \\
\hline $\begin{array}{l}\text { - Knowing how to identify hepatic } \\
\text { cirrhosis, its various forms, underlying } \\
\text { causes, portal hypertension and its } \\
\text { physiopathology } \\
\text { - Routinely using the Child-Turcotte-Pugh } \\
\text { score } \\
\text { - Recognising the general characteristics } \\
\text { of the cirrhotic patient from } \\
\text { a clinical-semeiological point of view: } \\
\text { muscular hypotrophy, palmar erythema, } \\
\text { spider nevi, caput medusa, flapping } \\
\text { tremor } \\
\text { - Knowing how to carry out screening of the } \\
\text { possible etiopathogenesis of cirrhosis: } \\
\text { ET_OH (alcohol and alcohol abuse) } \\
\text { dependent, post viral HCV (hepatitis C } \\
\text { virus), HBSAg (hepatitis B surface } \\
\text { antigen), occult HBV (hepatitis B virus) } \\
\text { mocromatosic (hyperferritinemia, } \\
\text { percentage of saturation of transferrin), } \\
\text { autoimmune (autoantibodies, } \\
\text { hypergammaglobuminaemia), M. Wilson } \\
\text { (deficit of ceruloplasmin and } \\
\text { hypercupremia, from deficit of alpha } \\
1 \text { antitrypsin, post-NASH, post-iatrogen } \\
\text { (antituberculotic) }\end{array}$ & $\begin{array}{l}\text { - Knowing how to manage portal } \\
\text { hypertension and the esophageal varices } \\
\text { complicated by bleeding with } \\
\text { pharmacological therapy: glypressin, } \\
\text { somatostatin, octreotide } \\
\text { - Knowing how to evaluate the significance } \\
\text { of measurements such as autoantibodies: } \\
\text { - antinuclear (ANA) } \\
\text { - smooth muscle (SMA) } \\
\text { - liver-kidney microsomal (LKM) } \\
\text { - anti-mitochondrial (AMA) and genetic } \\
\text { tests (C282 Y // H 63 D) } \\
\text { - Knowing how to carry out screening of } \\
\text { sensory-motor polyneuropathy } \\
\text { - Knowing how to carry out therapy for } \\
\text { primary biliary cirrhosis (PBC) and } \\
\text { primary schlerosing cholangitis (PSC) } \\
\text { - Knowing how to manage refractory } \\
\text { ascites } \\
\text { - Organising and managing direct } \\
\text { haemodialysis outpatient follow-up } \\
\text { - Facilitating the discharge plan } \\
\text { immediately from the start of the } \\
\text { hospitalisation }\end{array}$ & $\begin{array}{l}\text { - Utilising the METAVIR fibrosis score and } \\
\text { Ishak Index } \\
\text { - Giving indications for a transjugular } \\
\text { intrahepatic portosystemic shunt (TIPS) } \\
\text { - Knowing how to carry out the positioning } \\
\text { of a Sengstaken-Blakemore probe as a } \\
\text { buffer measure before a new attempt at } \\
\text { endoscopic therapy or a radiological } \\
\text { portosystemic derivative operation } \\
\text { (TIPS) or surgery } \\
\text { - Organising, coordinating or participating } \\
\text { in the development of guidelines and } \\
\text { protocols for the prevention of } \\
\text { neoplastic disease in the cirrhotic } \\
\text { patient }\end{array}$ & $\begin{array}{l}\text { - Carrying out fine needle aspiration and/ } \\
\text { or echo-guided microbiopsies and/or } \\
\text { ablations with ecography } \\
\text { - Carrying out hepatic ecography with } \\
\text { contrast medium } \\
\text { - Carrying out emergency/elective } \\
\text { endoscopic exams } \\
\text { - Knowing how to manage antiviral } \\
\text { therapies } \\
\text { - Managing a varicose haemorrhage with } \\
\text { sclerosis/ligature } \\
\text { - Carrying out the follow-up of liver } \\
\text { transplanted patients } \\
\text { - Choosing and formulating interventional } \\
\text { radiological therapy by TIPS positioning in } \\
\text { untreatable ascites or in the recurrence of } \\
\text { bleeding in the upper digestive tract } \\
\text { - Knowing how to manage bleeding from } \\
\text { varicose haemorrhage with early TIPS if } \\
\text { HVPG (hepato poral venous gas) > } 20 \\
\text { mmHg or high clinical risk } \\
\text { - Determining the timing for sending the } \\
\text { patient for liver transplantation } \\
\text { - Clinical choice between the known options } \\
\text { of treatment for evolutive hepatic } \\
\text { neoplastic diseases such as: }\end{array}$ \\
\hline
\end{tabular}


- Clinically differentiating compensated from uncompensated cirrhosis by semeiological evidence of

endoabdominal effusion and/or right hydrothorax, scrotal edema and bilateral lower limb edema

- Managing the possible complications of uncompensated cirrhosis such as:

recurrent encephalopathy, type 1 and 2 hepatorenal syndrome, spontaneous bacterial peritonitis, electrolytic disequilibrium (hypoatraemia,

hypopotassemia), relapsing right hydrothorax (thoracentesis and/or proposition of pleural talc),

hepatopulmonary syndrome, primary liver cancer

- Knowing how to carry out programming outpatient follow-up by carrying out biochemical tests quarterly (including the termination of alphaphetoprotein) and abdominal ecography semi-annually for the prevention of primary hepatic neoplasias

- Recognising the proteic synthesis deficit of the cirrhotic organ with evidence of hypoalbuminaemia

hypocholesterolaemia,

hypotransferrinaemia,

hypoprothrombinaemia or increase in the INR (International Normalised Ratio)

- Formulating diuretic and osmolar therapy which does not negatively affect renal function and the activity of the superio neurological sphere

- Documenting the therapeutic plan and the discharge instructions, interacting with the physician responsible for the outpatient/hospital follow-up and/or the family doctor

- Carrying out evacuative and exploratory paracentesis

- Knowing the precipitating factors of decompensation in the cirrhotic patient such as diuretics, dehydration, sepsis, alcohol, etc.
PEI (pancreatic exocrine insufficiency) (alcoholisation), PAI (percutaneous acetic acid injection), TACE (transarterial chemoembolisation), TAE (transarterial embolisation), laser therapy, RF (radiofrequency), radioactive 131 transarterial LIPIODOL 


\begin{tabular}{|c|c|c|c|}
\hline \multicolumn{4}{|c|}{ Management of hospital patients with gastrointestinal bleeding } \\
\hline Basic professionalism & Optimal professionalism & Excellent professionalism & Distinctive professionalism \\
\hline 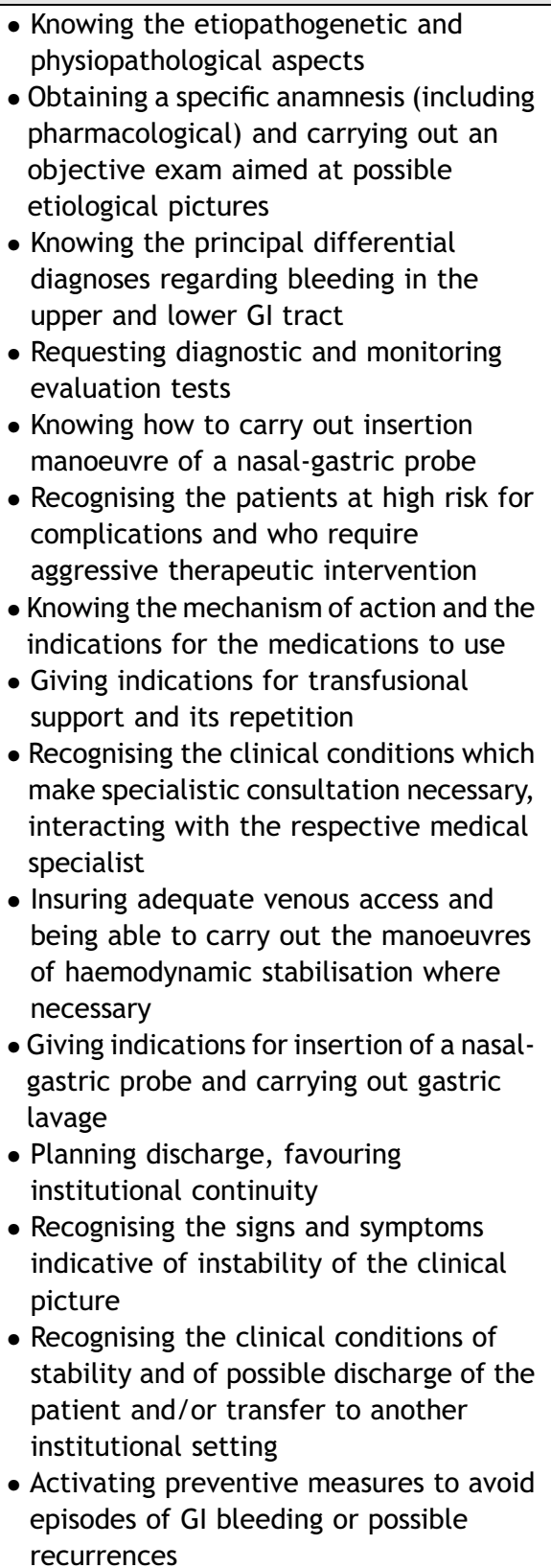 & $\begin{array}{l}\text { - Organising assistance for patients with } \\
\text { the greatest risk for with recurring } \\
\text { episodes of GI bleeding } \\
\text { - Proposing risk scores to identify the } \\
\text { patients with a serious prognosis } \\
\text { - Evaluating the advantages/ } \\
\text { disadvantages relative to medical- } \\
\text { pharmacological, endoscopic and } \\
\text { surgical treatment } \\
\text { - Procedures for diagnosis and } \\
\text { methodologies of treatment of possible } \\
\text { accompanying coagulopathies } \\
\text { - Carrying out a clinico-laboratory and } \\
\text { imaging technique synthesis in order to } \\
\text { formulate a comprehensive treatment } \\
\text { plan (pharmacological, nutritional, } \\
\text { endoscopic and surgical) } \\
\text { - Activating a multidisciplinary approach } \\
\text { involving specialist and specialised staff } \\
\text { - Knowing the indications (occult } \\
\text { gastrointestinal bleeding with EGDS } \\
\text { (esophagogastroduodenoscopy) and } \\
\text { negative colonoscopy, Crohn's disease, } \\
\text { NSAID (Non-steroid anti-inflammatory } \\
\text { drug) polyps of the small intestine, } \\
\text { neoplastic pathology, chronic diarrhoea } \\
\text { of unknown origin) and the } \\
\text { contraindications of the application of a } \\
\text { videocapsule (occlusion or pseudo- } \\
\text { occlusion of the alimentary tract, } \\
\text { notable stenosis of the gastrointestinal } \\
\text { tract, pregnancy, past major abdominal } \\
\text { surgery (relative), intestinal motor } \\
\text { pathology, swallowing, Zenker's } \\
\text { diverticulum) }\end{array}$ & $\begin{array}{l}\text { - Knowing how to classify congestive } \\
\text { gastropathy according to NIEC (North } \\
\text { Italian Endoscopic Club) } \\
\text { - Knowing how to classify esophageal/ } \\
\text { gastric varices according to NIEC (North } \\
\text { Italian Endoscopic Club) and Sarin } \\
\text { - Knowing how to identify haemorrhagic } \\
\text { risk on the basis of some elements, } \\
\text { such as: } \\
\text { - WHVPG }<10-12 \text { mm Hg (Wedged } \\
\text { hepatic venous portal gradient } \\
\text { - size of the varices } \\
\text { - esophagitis } \\
\text { - red signs } \\
\text { - haematocysts } \\
\text { - varice on varice } \\
\text { - stage of the cirrhosis } \\
\text { - recent NSAID bleeding } \\
\text { - Coordinating/participating in a } \\
\text { multidisciplinary team ivolved in the } \\
\text { management of Gl bleeding } \\
\text { - Knowing how to carry out the positioning } \\
\text { of a Sengstaken-Blakemore probe as a } \\
\text { buffer measure before a new attempt } \\
\text { of endoscopic therapy, or a derivative } \\
\text { porto-systemic radiological (TIPS) or } \\
\text { surgical intervention } \\
\text { - Actively coordinating/participating in } \\
\text { the writing of guidelines and institutional } \\
\text { paths to render assistance to patients } \\
\text { with GI bleeding efficient and efficacious } \\
\text { - Participate in initiatives to improve the } \\
\text { quality of efficacious prevention, early } \\
\text { recognition and reduction of possible } \\
\text { complications } \\
\text { - Periodic reporting of the updating of the } \\
\text { scientific literature on the topic }\end{array}$ & $\begin{array}{l}\text { - Carrying out manoeuvres of digestive } \\
\text { endoscopy, also urgently, for the } \\
\text { treatment of acute GI bleeding } \\
\text { - Managing a varicose haemorrhage with } \\
\text { sclerosis/ligature } \\
\text { - Knowing how to manage bleeding from } \\
\text { a varicose haemorrhage with early TIPS } \\
\text { if WHVPG > } 20 \text { mmHG or other high } \\
\text { clinical risk }\end{array}$ \\
\hline
\end{tabular}




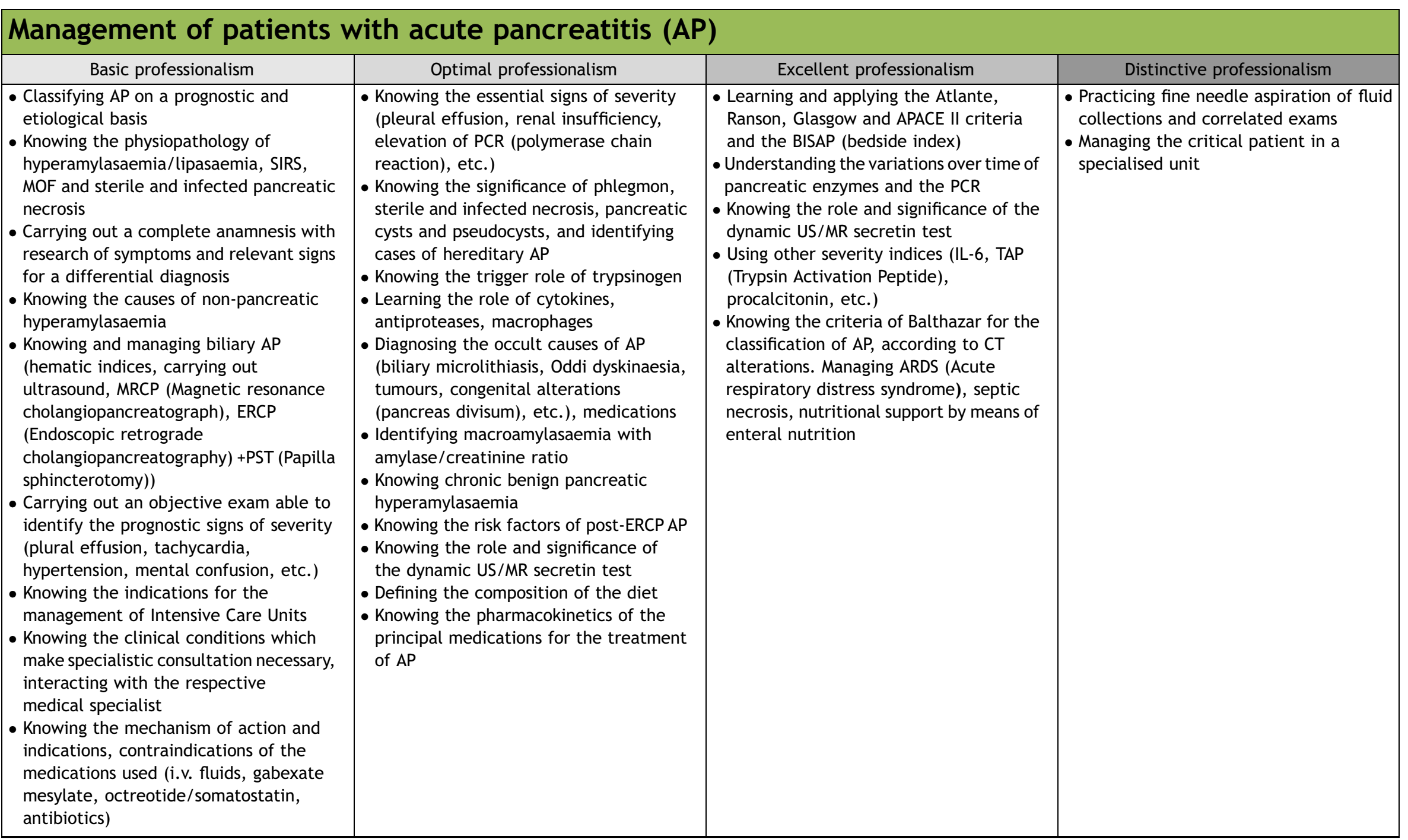




\section{Management of patients with chronic pancreatitis (CP)}

\begin{tabular}{|c|c|c|c|}
\hline Basic professionalism & Optimal professionalism & Excellent professionalism & Distinctive professionalism \\
\hline $\begin{array}{l}\text { - Classifying CP on an etiological basis } \\
\text { - Differentiating the recurring form } \\
\text { from AP } \\
\text { - Recognising the signs of advanced disease } \\
\text { (diabetes, steatorrhea) } \\
\text { - Knowing the parenchymal } \\
\text { anatopathological alterations, including } \\
\text { pancreatic cysts and pseudocysts } \\
\text { - Knowing the physiological processes } \\
\text { which lead to steatorrhea and diabetes } \\
\text { - Obtaining a complete anamnesis } \\
\text { searching for risk factors, symptoms } \\
\text { and relevant signs in order to make a } \\
\text { differential diagnosis } \\
\text { - Recognising and managing obstructive } \\
\text { and autoimmune alcoholic CP } \\
\text { - Carrying out an objective exam able } \\
\text { to identify signs of malabsorption and } \\
\text { complications } \\
\text { - Recognising the clinical conditions which } \\
\text { make specialistic consultation necessary, } \\
\text { interacting with the respective medical } \\
\text { specialist } \\
\text { - Knowing the mechanism of action, } \\
\text { indications and contraindications of the } \\
\text { medications used (analgesics, pancreatic } \\
\text { extracts, octreotide/somatostatin, } \\
\text { antidiabetic) } \\
\text { - Explaining to the patient and family } \\
\text { members the prognosis of CP, possible } \\
\text { short- and long-term complications, } \\
\text { strategies to prevent recurrences, } \\
\text { treatment objectives, their adverse } \\
\text { effects, diet, discharge plan, treatment } \\
\text { of risk factors }\end{array}$ & $\begin{array}{l}\text { - Knowing the mechanisms of pancreatic } \\
\text { damage from alcohol, tobacco and } \\
\text { obstruction, and the processes of } \\
\text { autoimmunity } \\
\text { - Knowing the formulations of the } \\
\text { medications for treating steatorrhea } \\
\text { - Optimally managing secondary diabetes, } \\
\text { avoiding hypoglycaemia } \\
\text { - Measuring the quality of life of the } \\
\text { patient with CP and promoting } \\
\text { improvement through counselling } \\
\text { - Investigating the occult causes of CP } \\
\text { (biliary microlithiasis, Oddi dyskinaesia, } \\
\text { tumours, congenital alterations } \\
\text { (pancreas divisum), etc.) } \\
\text { - Recognising "painless" CP (evaluation } \\
\text { of blood levels, US, CT, EUS, MRCP, } \\
\text { functional tests) } \\
\text { - Knowing the significance of the tubeless } \\
\text { test } \\
\text { - Knowing therapeutic endoscopic } \\
\text { procedures (stent, PST, stone removal, } \\
\text { etc.) } \\
\text { - Interpreting the results of diagnostic } \\
\text { imaging (ultrasonography, spiral CT, } \\
\text { MRCP, etc.) } \\
\text { - Knowing the various surgical techniques } \\
\text { and their indications } \\
\text { - Choosing the composition of a diet for the } \\
\text { CP patient }\end{array}$ & $\begin{array}{l}\text { - Diagnosing all the minor forms } \\
\text { (autoimmune CP, tropical CP, } \\
\text { hereditary CP) } \\
\text { - Recognising the forms of secondary } \\
\text { pancreatic insufficiency (from diabetes, } \\
\text { IBD (Inflammatory bowel disease), celiac } \\
\text { disease, endocrinopathy, etc.) } \\
\text { - Knowing the role of trypsinogen, } \\
\text { antoproteases, the genetic } \\
\text { polymorphism of CFTR (Cystic fibrosis } \\
\text { transmembrane conductance regulator) } \\
\text { mutations, endoluminal digestion of } \\
\text { lipids, liposoluble vitamins, proteins } \\
\text { and saccharides } \\
\text { - Interpreting chronic pancreatic } \\
\text { hypermilasaemia } \\
\text { - Knowing the role and significance of } \\
\text { the dynamic US/MR secretin test } \\
\text { - Knowing the breath test with tagged } \\
\text { liquids } \\
\text { - Knowing the fecal tests for the diagnosis } \\
\text { of steatorrhea } \\
\text { - Giving the differential diagnosis of } \\
\text { pancreatic cystic formations } \\
\text { - Managing abdominal pain with analgesics } \\
\text { and knowing the indications for } \\
\text { neurolytic therapy }\end{array}$ & $\begin{array}{l}\text { - Carrying out fine needle aspiration of } \\
\text { pseudocysts and correlated exams }\end{array}$ \\
\hline
\end{tabular}




\section{Fever of unknown origin - FUO}

\begin{tabular}{|c|c|c|c|}
\hline Basic professionalism & Optimal professionalism & Excellent professionalism & Distinctive professionalism \\
\hline $\begin{array}{l}\text { - Knowing how to document the course of } \\
\text { fever, including the capacity to verify } \\
\text { factitious fever } \\
\text { - Knowing how to identify FUO } \\
\text { - Knowing the possible underlying } \\
\text { etiologies for the various forms of FUO } \\
\text { (classic, nosocomial, neutropenic and } \\
\text { HIV(human immune deficiency virus)- } \\
\text { associated) } \\
\text { - Recognising the possible causes of FUO } \\
\text { - Knowing how to recognise the conditions } \\
\text { of immune impairment } \\
\text { - Obtain an accurate anamnesis, aimed } \\
\text { at the etiological diagnosis of FUO } \\
\text { - Carry out an adequate physical exam } \\
\text { in the case of an FUO } \\
\text { - Proposing carrying out cultural exams } \\
\text { (blood culture and especially urine } \\
\text { culture) early, at admittance to hospital, } \\
\text { before starting antibiotic therapy } \\
\text { - Planning first level investigations for } \\
\text { the diagnosis of FUO } \\
\text { - Appropriately proposing second level } \\
\text { diagnostic investigations for the } \\
\text { etiological diagnosis of FUO }\end{array}$ & $\begin{array}{l}\text { - Defining FUO in the various forms } \\
\text { described (classic, nosocomial, } \\
\text { neutropenic and HIV-associated) } \\
\text { - Involving the patient and family members } \\
\text { in the diagnostic challenge of FUO, with } \\
\text { a systematic, gradual and progressive } \\
\text { approach of the necessary diagnostic } \\
\text { investigations } \\
\text { - Classifying the possible diseases } \\
\text { underlying FUO in travellers returning } \\
\text { from tropical countries } \\
\text { - Eventually appropriately involving the } \\
\text { other specialists necessary for managing } \\
\text { the patient, since the multiplicity of } \\
\text { causes of FUO often requires a } \\
\text { multidisciplinary approach (laboratory, } \\
\text { haematologist, rheumatologist, } \\
\text { pneumologist, infectious diseases, } \\
\text { neurologist, surgeon, etc.) } \\
\text { - Recognising the possible conditions } \\
\text { correlated to reactivation of a tubercular } \\
\text { process or to latent tuberculosis } \\
\text { - Knowing how to recognise suspected cases } \\
\text { of acute meningitis } \\
\text { - Knowing how to recognise suspected cases } \\
\text { of acute/subacute encephalitis } \\
\text { - Recognising the causes of FUO associated } \\
\text { with splenomegaly } \\
\text { - Recognising the causes of FUO associated } \\
\text { with neutropenia } \\
\text { - Knowing how to interpret the study of } \\
\text { lymphocytic subpopulations } \\
\text { - Knowing how to correlate the } \\
\text { requirements of diagnostic imaging } \\
\text { (thoracic CT, abdominal (including the } \\
\text { pelvis), abdominal-pelvic CTwith contrast } \\
\text { medium, scintigraphy with radio-Gallio } 67 \\
\text { scan, scintigraphy with indium-labelled } \\
\text { leucocytes, scintigraphy with Tc } 99 \mathrm{~m} \text {, } \\
\text { NMR, PET-CT scan, transthoracic or } \\
\text { transesophageal echocardiography, } \\
\text { echocolourdoppler) in patients with FUO } \\
\text { with other possible underlying diagnoses }\end{array}$ & & $\begin{array}{l}\text { - Directly carry out transthoracic } \\
\text { echocardiography } \\
\text { - Directly carry out echosonographic } \\
\text { investigations for a first level approach } \\
\text { to FUO (privilege) } \\
\text { - Directly carry out an osteo-medullary } \\
\text { biopsy }\end{array}$ \\
\hline
\end{tabular}




\begin{tabular}{|c|c|c|c|}
\hline \multicolumn{4}{|c|}{ Management of Patients with Sepsis } \\
\hline Basic professionalism & Optimal professionalism & Excellent professionalism & Distinctive professionalism \\
\hline 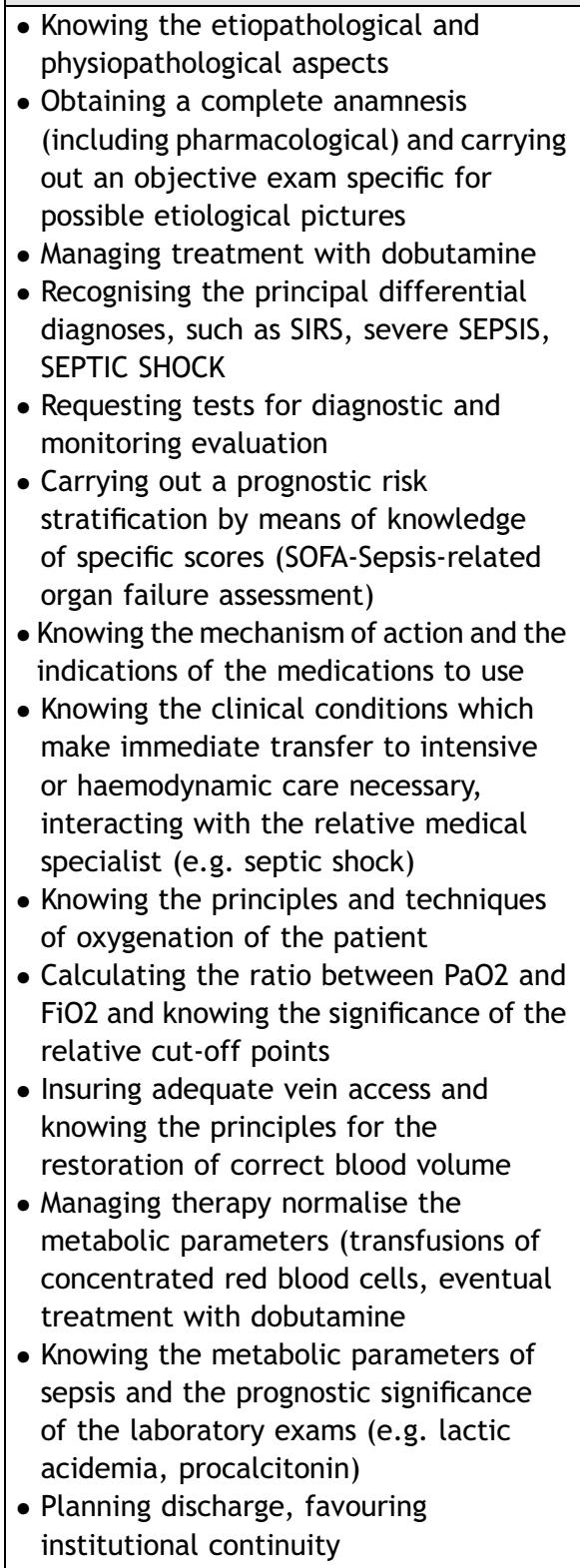 & $\begin{array}{l}\text { - Evaluating the relative advantages/ } \\
\text { disadvantages relative to } \\
\text { pharmacological and invasive treatment } \\
\text { - Rapidly identifying patients with septic } \\
\text { shock and treating them in an aggressive } \\
\text { manner while they are hospitalised in } \\
\text { intensive care units. Evaluating } \\
\text { cardiorespiratory stability and } \\
\text { implementing an aggressive restoration } \\
\text { of liquids, maintaining patent airways } \\
\text { and circulation support } \\
\text { - Concluding the correction of } \\
\text { hypovolaemia. Knowing the risk scores in } \\
\text { order to identify the patients with a } \\
\text { severe prognosis (e.g. SOFA) } \\
\text { - Knowing the procedures for diagnosis and } \\
\text { the methodologies for treating possible } \\
\text { complications } \\
\text { - Making a clinico-laboratory and imaging } \\
\text { technique synthesis in order to formulate } \\
\text { a complete diagnostic plan aimed at } \\
\text { specific complications }\end{array}$ & $\begin{array}{l}\text { - Supporting, coordinating and } \\
\text { participating in the development and } \\
\text { promotion of guidelines and paths which } \\
\text { facilitate an efficacious and rapid } \\
\text { evaluation and treatment of patients } \\
\text { with sepsis } \\
\text { - Actively coordinating/participating in } \\
\text { local implementation of guidelines and } \\
\text { institutional paths in order to render } \\
\text { assistance to patients with sepsis } \\
\text { efficient and efficacious } \\
\text { - Participating in initiatives for the } \\
\text { improvement of the quality of efficacious } \\
\text { prevention, early recognition and } \\
\text { reduction of possible complications } \\
\text { - Periodic reporting of the updating of the } \\
\text { scientific literature on the topic }\end{array}$ & $\begin{array}{l}\text { - Inserting and managing the use of PICC } \\
\text { and Midline venous catheters }\end{array}$ \\
\hline
\end{tabular}


- Recognising the signs and symptoms indicative of instability of the clinical picture

- Comprehensively managing the

medication for sepsis together with

eventual other medications for specific

chronic pathologies of the patient

- Knowing the principles and technique for

searching for pathogens

- Knowing the principles, techniques and

checks which permit correct suspension

of the antibiotic therapy

- Recognising the clinical conditions of

stability and possible discharge of the

patient and/or transfer to another

institutional setting

- Communicating to the patient and family

members the etiological aspect, the

prognosis, the diagnostic and therapeutic

indications and the follow-up program,

requesting the relative informed consent

\section{Management of Patients with depression}

\begin{tabular}{|c|c|c|c|}
\hline Basic professionalism & Optimal professionalism & Excellent professionalism & Distinctive professionalism \\
\hline $\begin{array}{l}\text { - Knowing how to identify depression with } \\
\text { a simple anamnestic approach } \\
\text { - Knowing how to recognise the symptoms } \\
\text { of depression with their corresponding } \\
\text { levels of severity: } \\
\text { - subthreshold depression symptoms } \\
\text { - light depression } \\
\text { - moderate depression } \\
\text { - severe psychotic-associated depression } \\
\text { symptoms } \\
\text { - Knowing how to carry out a complete } \\
\text { evaluation of the duration of the } \\
\text { symptoms and illnesses and/or } \\
\text { associated disabilities } \\
\text { - Knowing how to recognise depressed } \\
\text { patients on the basis of the socio- } \\
\text { economic context and associated } \\
\text { comorbidities }\end{array}$ & $\begin{array}{l}\text { - Knowing how to identify the symptoms of } \\
\text { depression with the following severity } \\
\text { levels: } \\
\text { - subthreshold depression symptoms } \\
\text { - light depression } \\
\text { - moderate depression } \\
\text { - severe psychotic-associated depression } \\
\text { symptoms } \\
\text { - Knowing how to consider possible } \\
\text { underlying metabolic causes in the } \\
\text { depressed adult patient (calcium or } \\
\text { magnesium alteration) } \\
\text { - Knowing how to classify depression } \\
\text { disturbances according to the DSM IV } \\
\text { (Diagnostic and Statistical manual of } \\
\text { Mental Disorders) and the ICD-10 } \\
\text { (International classification of } \\
\text { Diseases) }\end{array}$ & $\begin{array}{l}\text { - Knowing and applying the MARDS Scale } \\
\text { (Montgomery-Åsberg Depression Rating } \\
\text { Scale) for identifying patients at risk } \\
\text { for suicide } \\
\text { - Knowing how to recognise a pseudo- } \\
\text { depressive condition of dementia } \\
\text { - Knowing how to describe the mechanisms } \\
\text { of action of the following medications: } \\
\text { - tricyclics and their derivatives } \\
\text { - MAOI (Monoamine oxidase inhibitors } \\
\text { - SSRI (Selective serotonin reuptake } \\
\text { inhibitor) } \\
\text { - NARI (Noradrenaline reuptake inhibitor) } \\
\text { - NSRI (Noradrenaline and seratonin } \\
\text { reuptake inhibitor) (venlafaxin; Alpha } 2 \\
\text { antagonists (mirtazapine) } \\
\text { - NASSA (Noradrenergic and specific } \\
\text { serotoninergic antidepressants) }\end{array}$ & \\
\hline
\end{tabular}


- Knowing how to recognise patients with chronic illnesses potentially causing and/ or caused by depression

- Knowing how to recognise the cases which can be treated without a psychiatrist

- Knowing how to recognise the cases which have to be sent to a psychiatrist
- Knowing how to recognise patients at risk (and vice versa in protective conditions) of self-injurious and suicidal acts
Others: Trazodone, Nefazodone, Miansein St. John's Wort, S. Adenosylmethionine (SAME), amisulpride

\section{Management of Patients with delirium}

\begin{tabular}{l} 
Basic professionalism \\
\hline - Knowing how to identify delirium \\
according to DSM IV 7 (Diagnostic and \\
Statistical manual of Mental Disorders) \\
- Knowing the etiopatho-genetic and \\
physiopathological of delirium and \\
formulating basic therapy \\
- Knowing how to identify the causes of \\
delirium according to an etiological
\end{tabular}

delirium according to an etiological approach, e.g.: "VINDICATE": Vascular, Infections, Nutrition, Drugs, Injury,

Cardiac, Autoimmune, Tumours,

\section{Endocrine}

- Knowing how to obtain a complete anamnesis (including pharmacological) and carrying out an objective exam aimed at possible etiological pictures

- Recognising the principal predisposing conditions (dementia, pharmacological therapy, systemic illnesses,

postoperative, etc.)

- Knowing which diagnostic evaluation and monitoring tests to request

- Knowing how to stratify prognostic risk by means of knowledge of specific scores (Confusion Assessment Method (CAM))

- Knowing the mechanism of action and the indications of the medications to use

- Knowing how to recognise the clinical conditions of stabilisation and possible discharge of the patient and/or transfer to another institutional setting
Optimal professionalism

- Knowing how to identify and correct the causes of postoperative delirium: perisurgical cerebral hypoxia, arterial hypotension, surgical stress, use of narcotic drugs with anticholinergic activity, postsurgical pain, hydroelectrolytic alterations

- Knowing how to propose and apply risk scores to identify patients at high risk

- Evaluating the relative advantages/

disadvantages of treatment

- Knowing the procedures for diagnosing and the methodologies of treatment for the possible complications of delirium

- Knowing how to carry out a clinicolaboratory and imaging technique synthesis in order to formulate a comprehensive treatment plan

- Knowing how to activate measures for the prevention of delirium: avoiding, as much as possible, the use of at-risk medications [antidepressive tricyclics-type nortriptyline, barbiturates, benzodiazepine, antihistamines, spasmolytics, anti-Parkinson, antidiarrhoeal (difenossilate), muscle relaxants, codeine, digitalis, meperidine narcotics, morphine, prednisone, third generation cephalosporins]; maintain good hydration, avoiding hypoxia, treating acute pathologies rapidly, utilising orientation techniques (Reality orientation), correcting sensory deficits, keeping the environment well-lit and quiet

\section{Excellent professionalism}

- Knowing how to describe the environmental characteristics which increase the risk for dementia

- Coordinating/participating in a multidisciplinary team involved in managing delirium

- Coordinating/participating reactively in writing guidelines and institutional paths to render assistance to patients with delirium efficient and efficacious

- Participating in initiatives to improve the quality of efficacious prevention, and the early recognition and reduction of possible complications

- Periodic reporting of the updating of the scientific literature on the topic

- Knowing and suggesting the use of more adequate instruments for the evaluation of delirium in various institutional settings (Confusion Assessment Method (CAM), Delirium Rating Scale (DRS), Delirium Symptom Interview (DSI), Memorial Delirium Assessment Scale (MDAS)

- Knowing how to organise assistance to patients at greater risk for developing delirium 
Cognitive dysfunction - dementia

\begin{tabular}{|c|c|c|c|}
\hline Basic professionalism & Optimal professionalism & Excellent professionalism & Distinctive professionalism \\
\hline $\begin{array}{l}\text { - Knowing how to describe dementia and } \\
\text { its various manifestations } \\
\text { - Alzheimer's Disease (AD) } \\
\text { - Vascular ischemic (VD) or multi-infarct } \\
\text { dementia (MID) } \\
\text { - Degenerative non-Alzheimer's } \\
\text { dementia } \\
\text { - frontotemporal dementia } \\
\text { - Lewy body dementia and normal } \\
\text { pressure hydrocephalus } \\
\text { - Knowing how to conduct an initial clinical } \\
\text { evaluation: } \\
\text { - specific anamnesis } \\
\text { - physical and neurological exam } \\
\text { - evaluation of social condition } \\
\text { - evaluation of functional status } \\
\text { - evaluation of mental state } \\
\text { - Evaluation of pathologies and } \\
\text { medications } \\
\text { - Knowing how to differentiate the various } \\
\text { clinico-instrumental characteristics of } \\
\text { the most frequent forms of dementia } \\
\text { - Knowing how to classify dementia } \\
\text { according to its etiology } \\
\text { - Knowing how to exclude the presence of } \\
\text { delirium or depression } \\
\text { - Knowing how to identify mild cognitive } \\
\text { dysfunction (MCD) } \\
\text { - Knowing how to propose a useful and } \\
\text { appropriate diagnostic instrumental } \\
\text { protocol for diagnostic purposes } \\
\text { (laboratory exams, cardiovascular } \\
\text { exams, CT, NMR, PET, SPECT, etc.) } \\
\text { to "Specialised Centres" }\end{array}$ & $\begin{array}{l}\text { - Knowing how to apply the criteria for } \\
\text { diagnosing Alzheimer's Disease } \\
\text { - Knowing how to apply the criteria for } \\
\text { diagnosing vascular dementia } \\
\text { - Knowing how to apply the criteria for } \\
\text { clinically diagnosing frontotemporal } \\
\text { dementia and recognising its clinical } \\
\text { profile } \\
\text { - Knowing how to evaluate the risk for } \\
\text { conversion of MCD to dementia } \\
\text { - Knowing how to evaluate anamnestic/ } \\
\text { mnemonic impairment and the type of } \\
\text { memory impairment } \\
\text { - Knowing how to evaluate the presence of } \\
\text { cognitive deficits, such as: } \\
\text { - aphasia-language disorders } \\
\text { - apraxia } \\
\text { - agnosia } \\
\text { - deficit of critical thought and the } \\
\text { capacity to criticise } \\
\text { - Knowing how to evaluate the functional } \\
\text { state (ADL (Activity of daily living)-IADL } \\
\text { (Instrumental Activity of Daily Living) } \\
\text { - Knowing how to apply the Geriatric } \\
\text { Depression Scale } \\
\text { - Knowing how to recognise cases of } \\
\text { "curable dementia" (e.g. normal } \\
\text { pressure hydrocephalus) }\end{array}$ & $\begin{array}{l}\text { - Knowing how to carry out a Clock Drawing } \\
\text { Test for the screening of dementia } \\
\text { - Knowing how to evaluate CSF markers } \\
\text { (Creutzfeldt-Jakob syndrome-CJD): } \\
\text { - neuronal protein } 14.3 .3 \\
\text { - very elevated level of Tau protein } \\
\text { - decrease in A } \beta \text { level (42) } \\
\text { Alzheimer's Disease: } \\
\text { - decrease in A } \beta \text { level (42) } \\
\text { - increase in Tau protein levels } \\
\text { - Tau-hyperphosphorylate proposed as } \\
\text { the best CSF marker with respect to } \\
\text { total Tau } \\
\text { - Knowing how to evaluate the } \\
\text { characteristics of the results of cerebral } \\
\text { neuroimaging associated with vascular } \\
\text { dementia } \\
\text { - Knowing how to manage therapy with } \\
\text { inhibitors of: acetylcholine-esterases } \\
\text { (Ach-Els), such as donezepil, } \\
\text { rivastigmine, galantamin }\end{array}$ & $\begin{array}{l}\text { - Knowing how to carry out a neuro- } \\
\text { psychological evaluation } \\
\text { - Knowing how to carry out the follow-up of } \\
\text { a patient in the context/in collaboration } \\
\text { with "Specialised Centres" }\end{array}$ \\
\hline
\end{tabular}




\begin{tabular}{|c|c|c|c|}
\hline Pain & & & \\
\hline Basic professionalism & Optimal professionalism & Excellent professionalism & Distinctive professionalism \\
\hline $\begin{array}{l}\text { - Knowing types of pain } \\
\text { - Knowing and utilising pain scales in } \\
\text { relation to the type of patient } \\
\text { - Knowing the WHO scale of pain therapy } \\
\text { - Managing pain therapy } \\
\text { - Managing the adverse reactions of the } \\
\text { collateral effects correlated to pain } \\
\text { therapy }\end{array}$ & $\begin{array}{l}\text { - Knowing how to also utilise non-verbal } \\
\text { expression scales (e.g. in adult } \\
\text { demented patients) } \\
\text { - Managing pain also in more complex cases } \\
\text { and in those with resistant pain } \\
\text { - Modulating therapy with opioids } \\
\text { - Knowing and managing interactions of } \\
\text { pain medications with the medications } \\
\text { most commonly used for elderly people } \\
\text { - Knowing and managing the criteria of } \\
\text { conversion for opioids } \\
\text { - Knowing when to call pain specialists for } \\
\text { consultation }\end{array}$ & & \\
\hline
\end{tabular}

\section{Osteoporosis}

\begin{tabular}{|c|c|c|c|}
\hline Basic professionalism & Optimal professionalism & Excellent professionalism & Distinctive professionalism \\
\hline $\begin{array}{l}\text { - Knowing how to classify patients at risk } \\
\text { for osteoporosis on the basis of age, sex } \\
\text { (male or female), post-menopausal age, } \\
\text { race, familial anamnesis, physiology, } \\
\text { alimentation, physical activity, sun } \\
\text { exposure, medications, etc. } \\
\text { - Knowing how to administer questions for } \\
\text { self-evaluation of the patient at risk } \\
\text { for osteoporosis } \\
\text { - Knowing the minimum requirement of } \\
\text { nutritional intake of calcium and vitamin } \\
\text { D in pregnancy, in adults and in elderly } \\
\text { people } \\
\text { - Knowing the medications potentially able } \\
\text { to cause osteoporosis } \\
\text { - Knowing how to request first level } \\
\text { laboratory exams } \\
\text { - Knowing how to recognise cases of } \\
\text { factitious hypocalcaemia } \\
\text { - Knowing how to appropriately identify } \\
\text { patients who are candidates for } \\
\text { densitometry according to LEA }\end{array}$ & $\begin{array}{l}\text { - Knowing how to describe the differences } \\
\text { between primary and secondary } \\
\text { osteoporosis and recognise the } \\
\text { comorbidities which are possible causes } \\
\text { of osteroporosis } \\
\text { - Knowing the physiological implications of } \\
\text { Vitamin D hypovitaminosis } \\
\text { - Knowing how to request second level } \\
\text { laboratory exams } \\
\text { - Knowing how to recognise the utility and } \\
\text { limits of bone turnover markers } \\
\text { - of formation } \\
\text { § alkaline phosphatase (ALP) } \\
\text { § Bone-specific alkaline phosphatise } \\
\text { (BAP) } \\
\text { § Osteocalcin } \\
\text { § Procollagen type I C-terminal peptide } \\
\text { (PICP) } \\
\text { § Procollagen type I N-terminal } \\
\text { propeptide } \\
\text { - of reabsorption } \\
\text { § total alkaline phosphatase (ALP) } \\
\text { § Bone-specific alkaline phosphatise } \\
\text { (BAP) }\end{array}$ & $\begin{array}{l}\text { - Knowing the physiopathological } \\
\text { implications correlated to the RANK/ } \\
\text { RANKL/OPG Systems } \\
\text { - Receptor for the Activation of Nuclear } \\
\text { factor Kb expressed by pre-osteoclasts } \\
\text { - RANK-L (Ligand) expressed by OPG } \\
\text { osteoblasts produced by osteoblasts } \\
\text { - Knowing how to use the FRAX (Who } \\
\text { fracture Risk Assessment Tool) for } \\
\text { calculating the risk for fractures } \\
\text { based on age, BMI and BMD and on } \\
\text { the } 7 \text { dichotomous risk factors: } \\
\text { preceding fractures from fragility, } \\
\text { family history of fractures, } \\
\text { corticosteroid therapy, rheumatoid } \\
\text { arthritis, cigarette smoking, excessive } \\
\text { consumption of alcohol, presence of } \\
\text { conditions which induce bone } \\
\text { demineralisation } \\
\text { - Knowing how to calculate the risk factor } \\
\text { of fracture using the defragmentation } \\
\text { algorithm } \\
\text { - Knowing how to evaluate DXA (Dual- } \\
\text { energy X.ray Absorptiometry) }\end{array}$ & $\begin{array}{l}\text { - Knowing how to carry out QUS } \\
\text { - Knowing how to carry out DXA } \\
\text { - Knowing how to prescribe an } \\
\text { orthopaedic corset } \\
\text { - Knowing how to recognise patients } \\
\text { who are candidates for vertebroplasty } \\
\text { using an injection of } \\
\text { polymethylmethacrylate }\end{array}$ \\
\hline
\end{tabular}


$\S$ Osteocalcin

§ Procollagen type I C-terminal peptide (PICP)

§ Procollagen type I N-terminal propeptide

- Knowing the indication for and effects of strontium ranelate

- Knowing how to evaluate morphometry on the entire column (T4-L4) according to the semiquantitative morpho-

vertebral method of Genant

- Knowing how to interpret the data of densitometry on the basis of the T score

- Knowing how to recognise patients

worthy of/deserving treatment on the basis of:

- BMD (bone mineral

density) + age + other risk factors

- past vertebral fracture

- steroid therapy

- Knowing the best treatment on the basis of:

- diagnosis of secondary forms

- correction of modifiable risk factors

- Alimentation and physical exercise

- Sun exposure

- Intake of Vitamin D + calcium + necessity

of specific medications

- Knowing the various biphosphonates

(zolendronate, alendronate,

ibandronate, risedronate, etidronate,

clodronate, pamidronate, neridronate),

the indications, relative dosage, ways of

administration and collateral effects

- Knowing the indications and effects

of SERMs

- Knowing the indications and effects of teriparatide and the PTH (parathyroid hormone)

- Knowing how to identify non-responder patients after anti-reabsorptive therapy (alendronate, risedronate, raloxifene) for at least one year
- Knowing how to evaluate QUS (Quantitative Ultrasonography)

- Knowing how to evaluate QCT

(Quantitative Computed Tomography)

- Knowing how to differentiate

Morphometric Radiography (MRX) from morphometric assorbimetry (MXA),

with the respective advantages and

possible sources of error

- Knowing the differential

pharmacological characteristics of the various forms of Vit. $D$ on the market (cholecalciferol, dihydro-tachysterol, calcifediol, a-calcidiol)

- Knowing how to recognise and treat idiopathic hypercalciuria, with

increased excretion of urinary calcium

$(>4 \mathrm{mg} / \mathrm{kg} /$ day $)$, detectable in two

different determinations, in the

absence of systemic pathologies or

treatment (hyperthyroidism,

sarcoidosis, intoxication from Vit.D, etc.)

- Selecting patients at risk for dental problems (osteonecrosis, aseptic necrosis, osteomyelitis, odontogenic abscesses, gingival hypertrophy/ gingivitis, loss of teeth, etc.) of patients in or eligible for therapy - Knowing how to manage osteodystrophy in CRI patients 


\begin{tabular}{|c|c|c|c|}
\hline \multicolumn{4}{|l|}{ Arterial hypertension (AH) } \\
\hline Basic professionalism & Optimal professionalism & Excellent professionalism & Distinctive professionalism \\
\hline $\begin{array}{l}\text { - Classifying arterial hypertension (AH) } \\
\text { according to international guidelines } \\
\text { and according to the physiopathological } \\
\text { fundamentals of essential hypertension } \\
\text { (EH) and secondary hypertension (SH) } \\
\text { - Obtaining a complete anamnesis, } \\
\text { searching for symptoms suggestive of } \\
\text { the comorbidities which can influence } \\
\text { blood pressure control, compliance with } \\
\text { the therapy and the prognosis } \\
\text { - Investigating social conditions which can } \\
\text { influence blood pressure control } \\
\text { - Interpreting and evaluating modifiable } \\
\text { (salt, alcohol, life style, etc.) and non- } \\
\text { modifiable (familiarity, age, sex, etc.) } \\
\text { pre-disposing factors, clinical } \\
\text { presentation, laboratory reports, basic } \\
\text { exams to carry out and their } \\
\text { interpretation } \\
\text { - Carrying out an objective exam able to } \\
\text { identify the estimates of a possible } \\
\text { secondary hypertension (cushingoid } \\
\text { aspect, hypothyroidism, excessive } \\
\text { development of the thorax, etc.) } \\
\text { - Identifying the blood pressure objective } \\
\text { in the hospitalised patient, the } \\
\text { prognostic stratification and the } \\
\text { rationale of a strict control of the } \\
\text { arterial pressure (AP) on morbidity and } \\
\text { mortality } \\
\text { - Facilitating a discharge plan for the } \\
\text { hospitalised patient } \\
\text { - Utilising basic instrumental diagnostics } \\
\text { according to guidelines: ECG, first } \\
\text { level diagnostic screening for } \\
\text { secondary hypertension and for organ } \\
\text { damage, and the evaluation of } \\
\text { cardiovascular risk according to }\end{array}$ & $\begin{array}{l}\text { - Interpreting the principal tests, also } \\
\text { second level, for secondary hypertension } \\
\text { - Carrying out the screening and/or } \\
\text { diagnosis of particular types of } \\
\text { hypertension (pregnancy, elderly } \\
\text { people, young people, cardiopathic, } \\
\text { nephropathic, critical phase) } \\
\text { - Appropriately utilising instrumental } \\
\text { diagnostics according to guidelines: ECG, } \\
\text { echodoppler sat arterial echodoppler, } \\
\text { second level diagnostic tests for } \\
\text { secondary hypertension } \\
\text { - Utilising, from the moment of admission, } \\
\text { a multidisciplinary approach which can } \\
\text { include a nurse, dietician and } \\
\text { psychologist } \\
\text { - Recognising the indications for a second } \\
\text { level specialistic evaluation }\end{array}$ & $\begin{array}{l}\text { - Carrying out the principal tests, also } \\
\text { second level, for secondary hypertension } \\
\text { - Promoting the formation of a } \\
\text { multidisciplinary team, expert in } \\
\text { treating AH (perioperative hypertension, } \\
\text { in elderly people, in young peole, in } \\
\text { pregnancy, diabetes, gestational } \\
\text { diabetes, hypertensive crises, } \\
\text { nephropathy, cardiopathy, etc.) } \\
\text { - Organising, coordinating and } \\
\text { participating in the development of } \\
\text { guidelines and protocols for the } \\
\text { standardisation of the evaluation and } \\
\text { treatment of AH } \\
\text { - Organising, coordinating and } \\
\text { participating in the development of } \\
\text { guidelines and protocols for optimisation } \\
\text { of the control of AP in various situations } \\
\text { (perioperative, stroke, decompensation, } \\
\text { pregnancy, critical phase, } \\
\text { endocrinopathies) } \\
\text { - Organising, coordinating and } \\
\text { participating in the development of } \\
\text { guidelines and protocols for promoting } \\
\text { quality/efficacy of the management of } \\
\text { AH with a multidisciplinary approach } \\
\text { - Organising educational groups managed } \\
\text { by the specialist and the nurse, } \\
\text { adequately prepared to manage, with } \\
\text { the active participation of the patient, } \\
\text { problems with treatment, diet and other } \\
\text { related problems }\end{array}$ & $\begin{array}{l}\text { - Knowing how to carry out exams for the } \\
\text { ocular fundus and evaluating } \\
\text { hypertensive retinopathy according to } \\
\text { the Keith-Wagener-Barker classification } \\
\text { - Managing and/or carrying out dynamic } \\
\text { readings of AP (ABPM-ambulatory blood } \\
\text { pressure monitoring), echocardiogram, } \\
\text { echodoppler sat } \\
\text { - Carrying out instrumental exams, } \\
\text { hormonal dosage, and very specific } \\
\text { stimulation and suppression tests, } \\
\text { renal vessel echodoppler, } \\
\text { intra-arterial readings }\end{array}$ \\
\hline
\end{tabular}


ministerial tables

- Documenting a therapeutic plan and instructions for discharge, interacting with the physician responsible for outpatient follow-up and developing protocols for eventual return to the Hypertension Centre

- Explaining the objectives of a discharge and passage to careful follow-up treatment

- Choosing appropriate antihypertensive therapy, also in relation to cost/ benefit, diet and life style

- Regulating pharmacological therapy to reach optimal blood pressure control, minimising the collateral effects

- Explaining the mechanism of action,

indications and contraindications of the medications used for $\mathrm{AH}$

- Recognising and treating hypertensive crises

- Recognising the indications for a second level specialistic evaluation

- Explaining the history and prognosis of $\mathrm{AH}$ to the patient and family members, possible long-term complications and prevention strategies, treatment objectives, adverse effects, diet, discharge plan, importance of checking arterial pressure and possible selfmeasurement at home after brief training of the patient and family members, and treatment of $\mathrm{CV}$ risk factors 


\begin{tabular}{|c|c|c|c|}
\hline Basic professionalism & Optimal professionalism & Excellent professionalism & Distinctive professionalism \\
\hline $\begin{array}{l}\text { - Carrying out blood sampling and venous } \\
\text { cannulation } \\
\text { - Carrying out arterial sampling } \\
\text { - Thoracentesis } \\
\text { - Paracentesis } \\
\text { - Blood culture } \\
\text { - Urine culture } \\
\text { - Positioning of a vescical catheter } \\
\text { - Positioning of a naso-gastric probe } \\
\text { - Electrocardiography } \\
\text { - Basic diagnostic interpretation of ECG } \\
\text { (differentiation of atrial and ventricular } \\
\text { arrhythmias) }\end{array}$ & $\begin{array}{l}\text { - Positioning of a vescical catheter } \\
\text { (semirigid), also in more complex cases } \\
\text { - Arthrocentesis } \\
\text { - Thoracentesis, also in more complex } \\
\text { cases (slight effusion, sac-like } \\
\text { collections) } \\
\text { - Paracentesis, also in more complex } \\
\text { cases, pain management, sterile } \\
\text { procedures } \\
\text { - Knowing how to carry out diagnostic } \\
\text { interpretation, also in complex tracings }\end{array}$ & $\begin{array}{l}\text { - Venous catheter cannulation with PICC } \\
\text { (peripherally Inserted Central Catheter) } \\
\text { and midline } \\
\text { - Training professionals }\end{array}$ & $\begin{array}{l}\text { - Ocular fundus } \\
\text { - Rachicentesis } \\
\text { - Administering intrarachidian treatment } \\
\text { - Carry out and interpreting a Holter ECG } \\
\text { - Stress test }\end{array}$ \\
\hline
\end{tabular}




\section{Ultrasonography}

Basic professionalism

- Knowing the principles of the methodology and formation of ecographic images

- Knowing the limits of methodology, semantics and artefacts

- Knowing normal ecographic anatomy of organs which can be studied with ultrasound

- Knowing the principal applications of emergency and elective ecography

- Knowing the principles and applications of Doppler and echo-colour-doppler

- Knowing how to recognise:

- pleural effusion

- abdominal effusion

- pericardial effusion with early signs of cardiac tamponade

- abdominal aortic aneurysm

- I.V.C. (inferior vena cava) dilatation

- capacity of evaluating CVP (central venous pressure) indirectly utilizing the AP

(arterial pressure) of the inferior vena cava and it respiratory variations

- capacity of recognising the presence of distension of the jugular veins

- capacity of recognising the presence of EPA (acute pulmonary edema)

- pulmonary interstitiopathy

- urinary retention

- hydronephrosis

- renal calculi

- splenomegalia

- gallbladder hydrops

- gallstones

- obstructive jaundice

- pneumothorax

- capacity of recognising the presence of pneumothorax with lung point

- Knowing how to carry out:

- ultrasound-guided paracentesis

- ultrasound-guided toracentesis

- venous trunk/femoro-iliac compression ultrasonagraphy
Optimal professionalism

- Acquisition of the following competences, acquired with at least $120 \mathrm{~h}$ dedicated

to theoretic diagnostics $(20 \mathrm{~h})$, practical experience $(100 \mathrm{~h})$ and execution with

reporting of at least 250 ecographies

- Evaluation of the volume and thickness of the cardiac chambers

- Capacity of measuring the dimensions of the aortic root-left chambers,

left ventricular thickness, fractional shortening (FS)

- Capacity of evaluating the systolic function of the left ventricle (ejection fraction (EF), mean arterial pressures (MAPs), E-septum distance, etc.)

- Right chamber dimensions, tricuspid annular plane systolic excursion (TAPSE)

- Evaluation of "the maximum" of the regional kinetic alterations, in the various

short and long axis projections

- Evaluation of the EF Vsx (contraction of the left ventricle)

- Evaluation of valve function by means of echocolourdoppler

- Morphological M-Mode and aortic two-dimensional valve (sclerosis, calcifications) and mitral valve (calcifications, fibrosis, myxomatous degeneration, prolapse) evaluation - Semiquantitative mitral regurgitation $(/ 4+)$ and identification of mitral stenosis

- Velocity or maximum aortic gradient and semiquantitative evaluation of an eventual regurgitation $(/ 4+)$

- Qualitative evaluation of an eventual tricuspidal regurgitation (/4+) and estimate of PAPs (pulmonary arterial pressure)

- Capacity of evaluating the atrio-pulmonary gradient of shortening

- Diagnosis of acute and chronic pulmonary heart disease

- Capacity of identifying signs of hypertensive cardiopathy, various patterns of ventricular hypertrophy (eccentric, concentric, remodelling) and the principal cardiomyopathies

- Identification of valve vegetation

- Evaluation of the echo patterns and volumes of the abdominal parenchyma

- Evaluation of intra- and extra-parenchymal focal lesions

- Evaluation of the volume and thyroid echo pattern

- Evaluation of lymphoadenomegaly

- Ecocolourdoppler of the supra-aortic trunks (SATs)

- Recognising normal and pathological pictures: common carotid, external, internal, vertebral, subclavian, ophthalmic

- Measuring IMT (intima-medial thickness)

- Placque/Stenosis:

- ecographic characterisation of the plaque, quantification of the degree of stenosis occlusion

dissection

- spinal steal

obliterating arteriopathy of the AAll

measurement using the Windsor index

knowing normal and pathological Doppler pictures 
- quantification of the degree of stenosis

- endocardial cushion defect (ECD) of the aorta and iliac, common femoral artery,

superficial, deep, popliteal, tibial-peroneal trunk, posterior tibial, peroneal,

anterior tibial, pedicle

- aneurysmatic pathology: location, dimensions, complications

- post-catherisation arterial pseudoaneurysms

- complete venous ecocolourdoppler for the AAll (vena cava, iliac, common femur, superficial, deep, popliteal, subpopliteal: bigeminal, solear, peroneal, anterior and posterior tibial), CCUS (complete compression ultrasonography, suprapopliteal and subpopliteal veins)

- ecocolourdoppler evaluation of peripheral arterial stenosis

- knowing the techniques of echoguided cannulation of a peripheral vessel (basal or central (jugular and/or femoral) 


\begin{tabular}{|c|c|c|c|}
\hline \multicolumn{4}{|l|}{ Managing clinical records } \\
\hline Basic professionalism & Optimal professionalism & Excellent professionalism & Distinctive professionalism \\
\hline $\begin{array}{l}\text { - Complete and legible compilation of the } \\
\text { family and personal anamnesis, past } \\
\text { pathological anamnesis (with particular } \\
\text { attention to previous hospitalisations } \\
\text { and their reasons), future pathological } \\
\text { anamnesis of the temporal evolution of } \\
\text { the signs/symptoms in act, with careful } \\
\text { evaluation of the differential diagnosis } \\
\text { and degree of urgency or emergency } \\
\text { - Using the checklist in closing the clinical } \\
\text { records } \\
\text { - Complete compilation of what was } \\
\text { observed with the general objective } \\
\text { clinical exam and the various organs/ } \\
\text { systems } \\
\text { - Complete and legible compilation of the } \\
\text { clinical diary and the treatment } \\
\text { prescribed } \\
\text { - Management of informed consent when } \\
\text { carrying out diagnostic exams and } \\
\text { therapeutic treatments } \\
\text { - Correct and complete compilation of } \\
\text { HDRs (hospital discharge records) } \\
\text { - Recognition of the presence of a } \\
\text { pathology requiring isolation of the } \\
\text { patient }\end{array}$ & $\begin{array}{l}\text { - Using the checklist in closing the clinical } \\
\text { records } \\
\text { - Proposing actions aimed at improving the } \\
\text { hospital and completing the clinical } \\
\text { records, capacity of synthesis and } \\
\text { elevated epicrises }\end{array}$ & & $\begin{array}{l}\text { - Using APR-DRGs (All Patient Refined } \\
\text { Diagnosis Related Groups) } \\
\text { - Controlling and verifying the clinical } \\
\text { records of patients with particularly } \\
\text { complex and interdisciplinary } \\
\text { pathologies }\end{array}$ \\
\hline
\end{tabular}

\begin{tabular}{|c|c|c|c|}
\hline \multicolumn{4}{|c|}{ Degree of interaction in hospital } \\
\hline Basic professionalism & Optimal professionalism & Excellent professionalism & Distinctive professionalism \\
\hline $\begin{array}{l}\text { - Normal activity with hospital staff } \\
\text { (colleagues, nurses, etc.) of one's } \\
\text { Operative Unit (O.U.) and the } \\
\text { Administration }\end{array}$ & $\begin{array}{l}\text { - A correct DRG (Diagnosis Related Group) } \\
\text { and closing of the clinical record } \\
\text { - Visits- opinions of the the other O.U.s, } \\
\text { comparison of clinical and diagnostic } \\
\text { relationships with the staff of the other } \\
\text { hospital O.U.s and diagnostic services } \\
\text { - Operative collaboration with other } \\
\text { O.U.s, both of one's hospital and of other } \\
\text { hospitals }\end{array}$ & & \\
\hline
\end{tabular}




\section{Degree of complexity in relationships with other interlocutors external to the hospital}

\begin{tabular}{|c|c|c|c|}
\hline Basic professionalism & Optimal professionalism & Excellent professionalism & Distinctive professionalism \\
\hline $\begin{array}{l}\text { - Family doctors, external specialists, } \\
\text { regional physicians, pharmaceutical } \\
\text { representatives }\end{array}$ & & $\begin{array}{l}\text { - Collaborating on research projects, } \\
\text { experimentation and multicentric } \\
\text { studies }\end{array}$ & $\begin{array}{l}\text { - Promoting, directing and coordinating } \\
\text { research projects } \\
\text { - Collaborating with scientific associations, } \\
\text { regional or state offices }\end{array}$ \\
\hline
\end{tabular}

\begin{tabular}{|c|c|c|c|}
\hline \multicolumn{4}{|l|}{ Scientific didactic activity } \\
\hline Basic professionalism & Optimal professionalism & Excellent professionalism & Distinctive professionalism \\
\hline $\begin{array}{l}\text { - Participating in scientific abstracts/case } \\
\text { reports }\end{array}$ & $\begin{array}{l}\text { - Contributing to the efficacious formation } \\
\text { of students, colleagues, patients and } \\
\text { other people involved in the sector of } \\
\text { health assistance } \\
\text { - Exercising the function of a tutor for } \\
\text { students/younger learners } \\
\text { - Participating in scientific publications/ } \\
\text { original articles }\end{array}$ & & $\begin{array}{l}\text { - Professor in university and non-university } \\
\text { schools, and CME (Continuing Medical } \\
\text { Education) training courses } \\
\text { - Publishing in national and international } \\
\text { journals, being the first author }\end{array}$ \\
\hline
\end{tabular}

\begin{tabular}{|c|c|c|c|}
\hline \multicolumn{4}{|l|}{ Research } \\
\hline Basic professionalism & Optimal professionalism & Excellent professionalism & Distinctive professionalism \\
\hline - Participating in research studies & $\begin{array}{l}\text { - Coordinating observational studies and } \\
\text { clinical trials }\end{array}$ & & $\begin{array}{l}\text { - Promoting research studies } \\
\text { - Participating in international research } \\
\text { studies }\end{array}$ \\
\hline
\end{tabular}

